Fractions and Multiples of Units

\begin{tabular}{|llll|}
\hline Multiple & Decimal Equivalent & Prefix & Symbol \\
\hline $10^{6}$ & $1,000,000$ & & \\
$10^{3}$ & 1,000 & mega & $\mathrm{M}$ \\
$10^{2}$ & 100 & kilo & $\mathrm{k}$ \\
10 & 10 & hecto & $\mathrm{h}$ \\
$10^{-1}$ & 0.1 & deka & $\mathrm{da}$ \\
$10^{-2}$ & 0.01 & deci & $\mathrm{d}$ \\
$10^{-3}$ & 0.001 & centi & $\mathrm{c}$ \\
$10^{-6}$ & 0.000001 & milli & $\mathrm{m}$ \\
$10^{-9}$ & 0.000000001 & micro & $\mathrm{\mu}$ \\
$10^{-12}$ & 0.000000000001 & nano & $\mathrm{n}$ \\
$10^{-15}$ & 0.000000000000001 & pico & $\mathrm{p}$ \\
$10^{-18}$ & 0.000000000000000001 & femto & $\mathrm{f}$ \\
& & atto & $\mathrm{a}$ \\
\hline
\end{tabular}

Conversion Table

\begin{tabular}{|lll|lll|}
\hline Multiply & by & to Obtain & Multiply & by & to Obtain \\
\hline in & 2.54 & $\mathrm{~cm}$ & $\mathrm{~cm}$ & 0.394 & $\mathrm{in}$ \\
$\mathrm{ft}$ & 0.305 & $\mathrm{~m}$ & $\mathrm{~m}$ & 3.28 & $\mathrm{ft}$ \\
$\mathrm{mi}$ & 1.61 & $\mathrm{~km}$ & $\mathrm{~km}$ & 0.621 & $\mathrm{mi}$ \\
$\mathrm{lb}$ & 0.4536 & $\mathrm{~kg}$ & $\mathrm{~kg}$ & 2.205 & $\mathrm{lb}$ \\
$\mathrm{liq} q \mathrm{qt}$ (U.S.) & 0.946 & $\mathrm{~L}$ & $\mathrm{~L}$ & 1.057 & $\mathrm{liq} \mathrm{qt}$ \\
$\mathrm{ft}^{2}$ & 0.093 & $\mathrm{~m}^{2}$ & $\mathrm{~m}^{2}$ & 10.764 & $\mathrm{ft}^{2}$ \\
$\mathrm{ft}^{3}$ & 0.028 & $\mathrm{~m}^{3}$ & $\mathrm{~m}^{3}$ & 35.31 & $\mathrm{ft}^{3}$ \\
$\mathrm{~L}$ & $1 \times 10^{-3}$ & $\mathrm{~m}^{3}$ & $\mathrm{~m}$ & 1000 & $\mathrm{~L}$ \\
$\mathrm{Ci}$ & $3.7 \times 10^{10}$ & $\mathrm{~Bq}$ & $\mathrm{~Bq}$ & $2.7 \times 10^{-11}$ & $\mathrm{Ci}$ \\
$\mathrm{rad}$ & 0.01 & $\mathrm{~Gy}$ & $\mathrm{~Gy}$ & 100 & $\mathrm{rad}$ \\
$\mathrm{mrem}$ & 0.01 & $\mathrm{mSv}$ & $\mathrm{mSv}$ & 100 & $\mathrm{mrem}$ \\
\hline
\end{tabular}




\title{
Mound Site Environmental Report for Calendar Year 1991
}

\author{
June 1992 \\ Prepared by \\ EG\&G Mound Applied Technologies \\ P.O. Box 3000 \\ Miamisburg, $\mathrm{OH}$ 45343-3000 \\ and \\ Science Applications International Corporation \\ P.O. Box 2501 \\ Oak Ridge, TN 37831 \\ for the \\ U.S. Department of Energy \\ Under Contract
}

No. DE-AC04-88DP43495 


$$
\ldots
$$




\section{TABLE OF CONTENTS}

LIST OF FIGURES

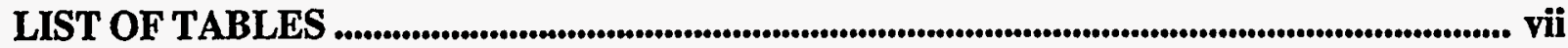



REPORT CONTRIBUTORS AND ACKNOWLEDGEMENTS ................................................. xi

EXECUTIVE SUMMARY ............................................................................................................................... ES-1

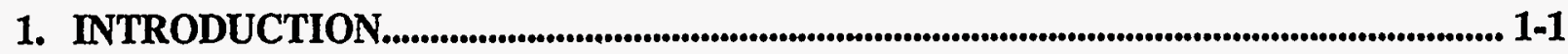

1.1 Description of Mound Site and Operations .......................................................................... 1-1

1.1 .1 Location ..................................................................................................................... 1-1

1.1.2 Mission and Operations .............................................................................................. 1-6

1.2 Perspective.on Radiation .................................................................................................. 1-8

2. COMPLIANCE SUMMARY ................................................................................................... 2-1

2.1 Major Environmental Statutes .................................................................................... 2-1

2.1.1 Clean Air Act .............................................................................................................. 2-1

2.1.2 Clean Water Act ............................................................................................................ 2-1

2.1.3 Safe Drinking Water Act .......................................................................................... 2-2

2.1.4 Resource Conservation and Recovery Act .......................................................... 2-2

2.1.5 Comprehensive Environmental Response, Compensation, and Liability Act .......... 2-3

2.1.6 Toxic Substance Control Act ............................................................................. 2-3

2.1.7 Emergency Planning and Community Right-to-Know Act (SARA Title III) ............ 2-4

2.1.8 Federal Insecticide, Fungicide, and Rodenticide Act ................................................ 2-4

2.1.9 National Environmental Policy Act ................................................................... 2-4

2.1.10 National Historic Preservation Act ....................................................................... 2-4

2.1.11 Endangered Species Act ............................................................................................. 2-4

2.1.12 Executive Order 11988, "Floodplain Management" ................................................... 2-5

2.1.13 Executive Order 11990, "Protection of Wetlands" .................................................... 2-5

2.2 Other Environmental Compliance Issues ........................................................................ 2-5

2.2.1 Tiger Team Action Plan ............................................................................... 2-5

2.2.2 Periding Lawsuit ........................................................................................... 2-5



2.4 Summary of Permits ................................................................................................................ 2-6

3. ENVIRONMENTAL PROGRAM INFORMATION .............................................................. 3-1

3.1 Overview of Environmental Monitoring Program ........................................................... 3-1

3.1.1 Rationale for Environmental Monitoring................................................................. 3-1

3.1.2 Determination of Environmental Concentrations ...................................................... 3-3

3.2 Overview of Environmental Activities .............................................................................. 3-5

3.2.1 Effluent Treatment and Waste Management .............................................................. 3-5

3.2.2 Environmental Restoration Program ................................................................. 3-6

3.2.3 Self-Assessment Activities ............................................................................. 3-6

3.2.4 Waste Minimization/Pollution Prevention .................................................................. 3-7

3.2.5 Environmental Training ................................................................................... 3-7

3.2.6 Review of Monitoring Practices ................................................................................. 3-7

3.2.7 Environmental Permits ........................................................................................ 3-8 


\section{TABLE OF CONTENTS (Continued)}

4. ENVIRONMENTAL RADIOLOGICAL PROGRAM INFORMATION ........................ 4-1

4.1 Air Monitoring Program ............................................................................................ 4-1

4.1.1 Description of Monitoring Program ....................................................................... 4-1

4.1.2 Applicable Standards ............................................................................................. 4-4

4.1.3 Results ...................................................................................................................... 4-4

4.2 Surface Water/Sediment/Groundwater Monitoring System ............................................. 4-8

4.2.1 Description of Monitoring Program ........................................................................ 4-8

4.2.2 Applicable Standards ...................................................................................... 4-8

4.2.3 Results ......................................................................................................... 4-11

4.2.4 Groundwater Trend Data .................................................................................. 4-22

4.3 . Foodstuffs and Vegetation ............................................................................................... 4-23

4.3.1 Description of Monitoring Program ....................................................................... 4-23

4.3.2 Applicable Standards ................................................................................................ 4-23

4.3.3 Results ..................................................................................................... 4-23

4.4 Methods of Calculating Offsite Radiation Dose .............................................................. 4-26

5. ENVIRONMENTAL NONRADIOLOGICAL PROGRAM INFORMATION............... 5-1

5.1 Air Monitoring Program .............................................................................................. 5-1

5.1.1 Description of Program .............................................................................................. 5-1

5.1 .2 Results ........................................................................................................................... 5-2

5.2 Surface Water Monitoring Program ..................................................................................... 5-3

5.2.1 Description of Monitoring Program.............................................................................. 5-3

5.2.2 Applicable Standards ................................................................................................. 5-3

5.2.3 Results ........................................................................................................................... 5:3

'5.3 Environmental Occurrences .......................................................................................... 5-5

5.4 Submissions Under SARA Title III ......................................................................... 5-5

6. GROUNDWATER PROGRAM............................................................................................ 6-1

6.1 Hydrology at Mound .............................................................................................. 6-1

6.1.1 Major Aquifers .................................................................................................... 6-1

6.1.2 Movement of Groundwater ................................................................................ 6-3

6.1.3 Uses of Groundwater in the Vicinity ..................................................................... 6-3

6.2 Applicable Standards ............................................................................................... 6-6

6.3 Description of Groundwater Program ................................................................................. 6-6

6.3.1 Tritium Contamination .................................................................................................. 6-8

6.3.2 VOC Contamination .......................................................................................... 6-10

6.3.3 Plutonium Analyses for Groundwater ................................................................. 6-16

7. ENVIRONMENTAL SURVEILLANCE QUALITY ASSURANCE ................................... 7-1

8. REFERENCES ................................................................................................................................ 8-1 


\section{LIST OF FIGURES}

E-1. Sources of annual radiation dose to an average individual versus Mound's maximum contribution ......................................................................................... ES-4

E-2. Tritium releases from Mound to the atmosphere .......................................................... ES-5

E-3. Tritium releases from Mound to the Great Miami River .............................................. ES-6

E-4. Plutonium-238 releases from Mound to the atmosphere ............................................. ES-7

E-5. Plutonium-238 releases from Mound to the Great Miami River .................................. ES-7

E-6. Plutonium-239,240 releases from Mound to the atmosphere ................................... ES-8

E-7. Plutonium-239,240 releases from Mound to the Great Miami River ......................... ES-8

E-8. Uranium releases from Mound to the atmosphere ..................................................... ES-9

E-9. Uranium-233,234 releases from Mound to the Great Miami River ........................... ES-9

1-1. Locations of the Mound Plant and surrounding communities ...................................... 1-1

1-2. Location of the Mound Plant ..................................................................................... 1-2

1-3. Distribution of population within 50 miles $(80 \mathrm{~km})$ of Mound ...................................... 1-3

1-4. Monthly rainfall for 1991 ........................................................................................ 1-4

1-5. 1991 wind speeds and directions ...................................................................................... 1-5

1-6. Mound site topography ............................................................................................... 1-7

4-1. Onsite air sampling locations ...................................................................................... 4-2

4-2. Offsite air sampling locations ....................................................................................... 4-3

4-3. Sampling locations for surface water effluents ......................................................... 4-9

4-4. Sampling locations for river water, surface water, and private wells ........................ 4-10

4-5. Locations of onsite production wells ......................................................................... 4-17

4-6. Annual average tritium concentrations in onsite production wells ............................ 4-22

4-7. Annual average plutonium-238 concentrations in onsite production wells ............... 4-23

6-1. Hydrogeologic environments in the vicinity of Mound ................................................. 6-2

6-2. Municipal and private well fields near Mound ............................................................... 6-4

6-3. Groundwater seep sampling locations on the Main Hill ............................................. 6-6

6-4. Water quality monitoring network for wells in the upper and lower units of . the Buried Valley Aquifer ................................................................................................... 6-7

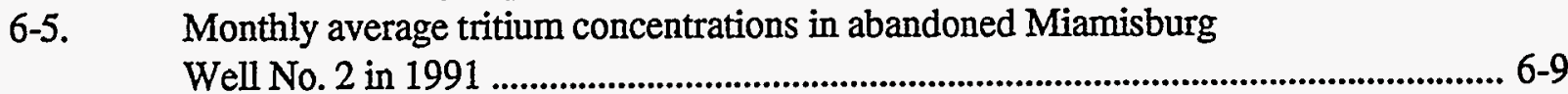




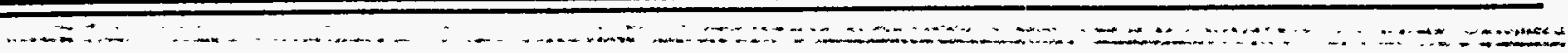




\section{- LIST OF TABLES}

E-1. Radiological Effluent Data for 1991 ES-2

E-2. Radiation Dose Limits for Protection of the Public from All Routine DOE Operations ES-3

E-3. Maximum Committed Effective Dose Equivalents to a Hypothetical Individual

1.1 Population Totals from the 1990 Census

1-2. Percent Frequency of Wind Direction and Wind Speed from the Mound

Meteorological Tower, Miamisburg, Ohio, for 1991

3-1. Summary of Mound's Monitoring Program

3-2. Environmental (Reference) Concentrations of Radionuclides in Various Media in 1991

3-3. Environmental Permits Issued to Mound

4-1. Incremental Concentrations of Plutonium-238 in Air at Sampling Locations in 1991 ..... 4-5

4-2. Incremental Concentrations of Tritium Oxide in Air at Sampling Locations in 1991 ...... 4-6

4-3. Incremental Concentrations of Plutonium-239,240 in Air at Sampling Locations in 1991

4-4. Incremental Concentrations of Tritium in the Great Miami River in 1991 ..................... 4-11

4-5. Incremental Concentrations of.Plutonium-238 in the Great Miami River in 1991 ........... 4-12

4-6. Incremental Concentrations of Uranium-233,234 and Uranium-238 in the Great Miami River.in 1991

4-7. Incremental Concentrations of Tritium in Surface Water in 1991 .................................. 4-14

4-8. Incremental Concentrations of Plutonium-238 in Surface Water in 1991 ....................... 4-14

4-9. Tritium Concentrations in Community Drinking Water in 1991 .................................. 4-15

4-10. Tritium Concentrations in Privately-Owned Wells in 1991 .......................................... 4-16

4-11. Tritium Concentrations in Onsite Wells in 1991 ....................................................... 4-16

4-12. Plutonium-238 Concentrations in Privately-Owned Wells and Miamisburg Municipal Drinking Water in 1991 .............................................................................. 4-18

4-13. Plutonium-238 Concentrations in Onsite Well Water in 1991 ....................................... 4-18

4-14. Uranium-233,234 and Uranium-238 Concentrations in a Privately-Owned Well and Miamisburg Municipal Drinking Water in 1991

4-15. Uranium-233,234 and Uranium-238 Concentrations in Onsite Well Water in 1991 ........ 4-20

4-16. Incremental Concentrations of Plutonium-238 in Silt from River Sampling Locations in 1991

4-17. Incremental Concentrations of Plutonium-238 in Silt from Surface Water Locations in 1991

4-18. Incremental Concentrations of Plutonium-238 in Foodstuffs and Vegetation in 1991 .... 4-24

4-19. Incremental Concentrations of Tritium in Foodstuffs and Vegetation in 1991 


\section{LIST OF TABLES (Continued)}

5-1. Nonradiological Airborne Effluent Data for 1991 ...................................................... 5-1

5-2. 1991 Particulate Concentrations ............................................................................... 5-2

5-3. National Pollution Discharge Elimination System Data for 1991 .................................... 5-4

5-4. Summary of Organic Compounds Detected in Mound Effluents in 1991 ........................ 5-5

5-5. Emergency and Hazardous Chemical Inventory Data for Mound ...................................... 5-6

6-1. Municipal Groundwater Use Within the Great Miami River Watershed ........................... 6-5

6-2. Tritium Concentrations in Mound Seep Sites in 1991 .................................................. 6-8

6-3. . Tritium Concentrations in BVA Monitoring Wells in 1991 ......................................... 6-10

6-4. Volatile Organic Concentrations in Groundwater Samples Collected from Seeps in 1991 ........................................................................................................ 6-11

6-5. Volatile Organic Concentrations in Groundwater Samples Collected from

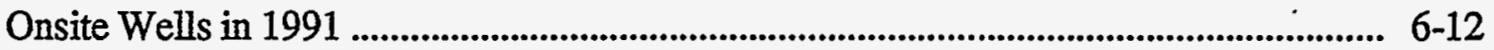

6-6. Volatile Organic Concentrations in Onsite Production Wells in 1991 ........................... 6-15

6-7. Volatile Organic Concentrations in Groundwater Samples Collected from Offsite Wells in 1991 .................................................................................................... 6-16

7-1. Mound DOE Quality Assessment Program Results for Radionuclides in Environmental Samples (March 1991 Samples) .......................................................... 7-1

7-2. Mound DOE Quality Assessment Program Results for Radionuclides in Environmental Samples (September 1991 Samples) ................................................... 7-2

7-3. 1991 Mound EPA-NPDES Quality Assurance Program Results for the Determination of Nonradioactive Parameters in Water ....................................................... 7-3

7-4. Summary of Mound's Performance in the Analytical Products Group Proficiency Environmental Testing Program for 1991 


\section{LIST OF ACRONYMS}

$\begin{array}{ll}\text { AIl } & \text { ALARA Investigation Level } \\ \text { ALARA } & \text { As Low As Reasonably Achievable } \\ \text { ANSI } & \text { American Nuclear Standards Institute } \\ \text { APG } & \text { Analytical Products Group, Inc. } \\ \text { BNA } & \text { Base, neutral, acid extractables } \\ \text { BUSTR } & \text { Bureau of Underground Storage Tank Regulations } \\ \text { BVA } & \text { Buried Valley Aquifer } \\ \text { CAA } & \text { Clean Air Act } \\ \text { CBOD } & \text { Carbonaceous biochemical oxygen demand } \\ \text { CEDE } & \text { Committed effective dose equivalent } \\ \text { CERCLA } & \text { Comprehensive Environmental Response, Compensation, and Liability Act } \\ \text { COD } & \text { Carbonaceous oxygen demand } \\ \text { CWA } & \text { Clean Water Act - : } \\ \text { DAO } & \text { Dayton Area Office } \\ \text { DCG } & \text { Derived Concentration Guide } \\ \text { DOE } & \text { U.S. Department of Energy } \\ \text { DWS } & \text { Drinking Water Standard } \\ \text { EA } & \text { Environmental Assessment } \\ \text { EDE } & \text { Effective dose equivalent } \\ \text { el. } & \text { Environmental level } \\ \text { EML } & \text { Environmental Measurements Laboratory } \\ \text { EPA } & \text { U.S. Environmental Protection Agency } \\ \text { ER } & \text { Environmental Restoration } \\ \text { ES\&H } & \text { Environment, Safety, and Health } \\ \text { FFA } & \text { Federal Facilities Agreement } \\ \text { FIFRA } & \text { Federal Insecticide, Fungicide, and Rodenticide Act } \\ \text { HEPA } & \text { High efficiency particulate air } \\ \text { LDL } & \text { Lower detection limit } \\ \text { LDR } & \text { Land Disposal Restriction } \\ \text { LSA } & \text { Low specific activity } \\ \text { MCL } & \text { Maximum contaminant level } \\ \text { MDL } & \text { Method detection limit } \\ \text { MGD } & \text { Million gallons per day } \\ \text { MRC } & \text { Monsanto Research Corporation } \\ \text { NEPA } & \text { National Environmental Policy Act } \\ \text { NESHAPs } & \text { National Emission Standards for Hazardous Air Pollutants } \\ \text { NHPA } & \text { National Historic Preservation Act } \\ \text { NPDES } & \text { National Pollution Discharge Elimination System } \\ \text { NPL } & \text { National Priorities List } \\ \text { NTS } & \text { Nevada Test Site } \\ \text { PCBs } & \text { Polychlorinated biphenyls } \\ \text { RAPCA } & \text { Regional Air Pollution Control Agency } \\ \text { RCRA } & \text { Resource Conservation and Recovery Act } \\ \text { RI/FS } & \text { Remedial Investigation/Feasibility Study } \\ & \end{array}$




\section{LIST OF ACRONYMS (CONTINUED)}

RQ Reportable quantity

SARA Superfund Amendments and Reauthorization Act

TRU Transuranic

TSCA Toxic Substances Control Act

TTOs Total Toxic Organics

UST Underground storage tank

VOC Volatile organic compound 


\section{REPORT CONTRIBUTORS}

This report was prepared by the Environment and Waste Management Section of EG\&GMound. The report was compiled by L.R. Bauer based on contributions from D.G. Carfagno, B.M. Farmer, J.P. Fontaine, W.D. Gloekler, J.R. Hausfeld, C. Kinard, L.M. Klinger, J.R. McKendree, L.L. Roush, M.R. Thomas, M.S. Tullis, R.S. Tunning, and D.A. Walls.

\section{ACKNOWLEDGEMENTS}

The environmental data presented in this report resulted from the sample collection and laboratory analysis efforts of K.E. DeVilbiss, P.E. Figgins, L.C. Hopkins, N.L. Hoseus, V.S. Johnson, V.C. Lacy, C.A. Phillips, D.E. Poteet, L.L. Roush, and M.R. Thomas.

Additional information on environmental programs at Mound was provided by R.E. Burdg, J. Janowiecki, K.G. Koehler, P.A. Parker, J.M. Walker, and S.L. Waskey. 
$\therefore$ 


\section{EXECUTIVE SUMMARY}

Mound is a government-owned facility operated by EG\&GMound Applied Technologies for the U.S. Department of Energy (DOE). This integrated production, development, and research site performs work in support of DOE's weapon and energy related programs, with emphasis on explosive, nuclear, and energy technology. The purpose of this report is to inform the public about the impact of Mound's operations on the population and the environment. This report summarizes data from the Environmental Monitoring Program, through which Mound maintains continuous surveillance of radiological and nonradiological substances released from the facility.

The Mound facility, named after the Miamisburg Indian Mound adjacent to the site, comprises 120 buildings on 124 hectares (306 acres) of land in Miamisburg, Ohio, approximately $16 \mathrm{~km}$ (10 mi) southwest of Dayton (Figure 1-1). The Great Miami River, which flows through the city of Miamisburg, dominates the five-county region surrounding Mound (Figure 1-2). The river valley is highly industrialized. The rest of the region is predominantly farm land dotted with light industry and small communities. The climate is moderate. The geologic record preserved in the rocks underlying Mound indicates that the area has been relatively stable since the beginning of the Paleozoic era more than 500 million years ago. No buildings at the Mound Plant are located in a floodplain or in areas considered wetlands.

\section{PERSPECTIVE ON RADIATION}

Radionuclides, radioactive species of atoms, emit ionizing radiation. Ionizing radiation is radiation that has enough energy to remove electrons from the substances through which it passes. Most consequences to humans from radionuclides released to the environment are caused by the interactions of ionizing radiations with human tissue. The units (rem, Sv) used to measure human dose relate the quantity of radiation absorbed to the biological effects on the exposed individual.

Every day our bodies absorb ionizing radiation. Most of this radiation comes from natural sources. The average dose to a resident of the United States from natural sources is about 300 mrem $(3.0 \mathrm{mSv})$ each year. Consumer products and medical procedures that use radiation are other common sources of exposure. Thesesources contribute $12 \mathrm{mrem}(0.12 \mathrm{mSv})$ and $53 \mathrm{mrem}$ $(0.53 \mathrm{mSv})$, respectively, to the average dose.

\section{IMPACT OF MOUND'S RADIONUCLIDE RELEASES}

Table E -1 lists the quantities of radionuclides released by Mound into the air and water during 1991. The unit used to report these quantities is the curie (Ci), a unit of radioactivity equal to 3.7 $\times 10^{10}$ disintegrations per second. The quantities, or activities, shown in Table E-1 were measured at the point the effluents were released. However, before any of these radionuclides reach man, they may travel through a number of different environmental pathways and/or undergo certain changes. For example, plutonium released into a waterway may be diluted by the volume of water in the stream yet be accumulated in the tissues of fish. 
Table E-1. Radiological Effluent Data for $\mathbf{1 9 9 1}$

\begin{tabular}{cccc}
\hline Radionuclide & $\begin{array}{c}\text { Half-Life } \\
\text { (years) }\end{array}$ & Medium & Activity \\
\hline Tritium & 12.3 & Air & $1232 \mathrm{Ci}^{\text {a }}$ \\
& & Water & $3.2 \mathrm{Ci}$ \\
Plutonium-238 & 87.7 & Air & $1.5 \times 10^{-5} \mathrm{Ci}$ \\
& & Water & $4.5 \times 10^{-4} \mathrm{Ci}$ \\
Plutonium-239,240 & 24,100 & Air & $5.5 \times 10^{-8} \mathrm{Ci}$ \\
& & Water & $9.7 \times 10^{-6} \mathrm{Ci}$ \\
Uranium-233,234 & ${ }^{233} \mathrm{U}: 159,200 ;{ }^{234} \mathrm{U}: 245,000$ & Air & $2.8 \times 10^{-8} \mathrm{Ci}$ \\
& & Water & $3.4 \times 10^{-4} \mathrm{Ci}$ \\
Uranium-238 & $4.47 \times 10^{9}$ & Air & $2.3 \times 10^{-8} \mathrm{Ci}$ \\
\hline
\end{tabular}

${ }^{2}$ Tritium in air consists of: Tritium oxide $=869 \mathrm{Ci}$

Elemental tritium $=363 \mathrm{Ci}$

The fish may then become food for man. Therefore, to calculate the actual impact of plutonium effluents, concentrations of plutonium in different environmental media - air, water, vegetation, and foodstuffs - must be measured. From these measurements the radiation dose received by an individual in the vicinity of Mound can be estimated.

\section{Dose Limits}

Dose limits, or more precisely dose equivalent limits, for members of the public are presented in Table E-2. These limits are expressed in terms of a committed effective dose' equivalent (CEDE) and an effective dose equivalent (EDE) for the DOE and EPA, respectively. The presentation of dose limits in this fashion, CEDE and EDE, is a mechanism for comparing relative risks from different types of ionizing radiation absorbed from various exposure pathways. Values shown in Table E-2 represent the annual limits on dose equivalents established by the DOE and EPA.

\section{Dose Equivalents from Mound Operations}

In calculating the maximum dose received by a member of the public from Mound's operations, a committed effective dose equivalent is used. The CEDE is the dose received by a hypothetical 


\section{Table E-2. Radiation Dose Limits for Protection of the Public} from All Routine DOE Operations

\begin{tabular}{|c|c|c|c|}
\hline \multirow[b]{2}{*}{ Pathway } & \multirow{2}{*}{$\begin{array}{l}\text { Regulatory } \\
\text { Standard }\end{array}$} & \multicolumn{2}{|c|}{$\begin{array}{c}\text { Effective } \\
\text { Dose Equivalent }\end{array}$} \\
\hline & & mrem & $\mathrm{mSv}$ \\
\hline All - occasional exposure & DOE Order 5400.5 & 500 & 5 \\
\hline All - prolonged exposure (> 5-yr period) & DOE Order 5400.5 & 100 & 1 \\
\hline Air & 40 CFR 61 (EPA) & 10 & 0.1 \\
\hline Drinking water & 40 CFR 141 (EPA) & 4 & 0.04 \\
\hline
\end{tabular}

Evaluated based on annual exposure conditions.

individual who remained at the site boundary 24 hours per day throughout 1991 . This individual was assumed to have:

- continually breathed air containing the maximum radionuclide concentrations found at an onsite air sampling station,

- drawn all of his drinking water from the offsite well with the maximum radionuclide concentrations, and

- consumed a portion of the offsite foods exhibiting the maximum radionuclide concentrations.
The dose contributions from all of these pathways are added to obtain an estimate of the maximum total CEDE. Table E-3 shows the results for Mound that have been calculated based on sampling data gathered by the Environmental Monitoring Program. The results are reported for tritium and plutonium-238 exclusively. The other radionuclides released by Mound were present in concentrations that were below environmental levels or were too small to affect the overall doses repported in Table E-3.

Table E-3. Maximum Committed Effective Dose Equivalents to a Hypothetical Individual

\begin{tabular}{|c|c|c|c|c|}
\hline Radionuclide & Pathway & mrem & $\mathrm{mSv}$ & $\begin{array}{c}\text { Percent of } \\
\text { DOE Dose Standard }\end{array}$ \\
\hline \multirow[t]{2}{*}{ Plutonium-238 } & 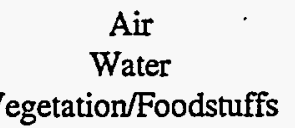 & $\begin{array}{l}0.11 \\
0.001 \\
0.06\end{array}$ & $\begin{array}{l}0.0011 \\
0.000011 \\
0.0006\end{array}$ & $\begin{array}{l}0.11 \\
0.001 \\
0.06\end{array}$ \\
\hline & Total & 0.17 & 0.0017 & 0.17 \\
\hline \multirow[t]{2}{*}{ Tritium } & $\begin{array}{l}\text { Air } \\
\text { Water } \\
\text { egetation/Foodstuffs }\end{array}$ & $\begin{array}{l}0.03 \\
0.06 \\
0.02\end{array}$ & $\begin{array}{l}0.0003 \\
0.0006 \\
0.0002\end{array}$ & $\begin{array}{l}0.03 \\
0.06 \\
0.02\end{array}$ \\
\hline & Total & 0.11 & 0.0011 & 0.11 \\
\hline Plutonium-238 and Tritium & Total & 0.28 & 0.0028 & 0.28 \\
\hline
\end{tabular}


A comparison of Table E-3 with Table E-2 shows that the maximum CEDE to an individual from tritium and plutonium-238 was 0.28 mrem (0.0028 mSv). This CEDE represents $0.28 \%$ of the DOE standard (100 mrem; $1 \mathrm{mSv}$ ) for prolonged exposure.

Additionally, Figure E-1 shows that the maximum dose from Mound's effluents represents only a small fraction, $0.1 \%$, of the CEDE an average individuals absorbs from natural, medical, and consumer sources.

The population (approximately 3,035,000 persons) within a radius of 80 kilometers ( 50 miles) received an estimated 3.6 person-rem $(0.036$ person-Sv) from Mound's operations in 1991. This value was determined using the EPA computer code CAP-88. CAP-88 calculates average doses to individuals in areas around a release point, then multiplies each average dose by the number of individuals in the corresponding area. (For example, an average dose of $0.001 \mathrm{rem} \times 10,000$ people in the area yields a dose of 10 person-rem.)

Mound's dose contribution of 3.6 person-rem can be compared to the almost 1 million personrem a population of 3 million people receive each year from natural sources.

Because the doses presented in this report are calculated rather than measured, they represent estimated rather than actual doses. However, elements of conservatism are included in each stage of the dose calculation process.



Figure E-1. Sources of annual radiation dose to an average individual versus Mound's maximum contribution 


\section{5-Year Trends in Radionuclide.Releases}

It is Mound policy and philosophy that all releases of effluents from the Plant are ALARA, that is, As Low As Reasonably Achievable. To monitor Plant performance relative to ALARA goals, ALARA Investigation Levels (AIls) are established each year for principal radionuclides. AILs are intentionally set well below applicable regulatory standards to trigger internal investigations when exceeded. In that sense, Alls act as indicators of potential problems requiring additional attention.

Figure E-2 through E-9 illustrate 5-year trends in releases of tritium, plutonium, and uranium to the air and to the Great Miami River. Mound's
1991 AILs have also been included on the trend charts-where appropriate.

Tritium. Figure E-2 shows releases of tritium to the atmosphere. The 1989 peak can be attributed to an accidental release. In 1989, however, the average concentration of tritium measured at offsite locations was $0.009 \%$ of the DOE Derived Concentration Guide (DCG) for tritium in air. The 1991 value, $1232 \mathrm{Ci}$, represents a 5-year low in release rates. Figure $\mathrm{E}-3$ shows tritium releases to the Great Miami River. The 3.2 Ci in 1991 also represents the 5-year low. In 1991, tritium releases to the atmosphere and the Great Miami River did not approach the Alls.



1991 ALARA Investigation Level $=7000$ Curies

Figure E-2. Tritium releases from Mound to the atmosphere 




1991 ALARA Investigation Level $=20$ Curies

Figure E-3. Tritium releases from Mound to the Great Miami River

Plutonium-238. Figures E-4 and E-5 show plutonium-238 releases to the atmosphere and Great Miami River, respectively. Both types of releases decreased in 1991 relative to 1990 and the Alls were not exceeded.

Plutonium-239,240. Figures E-6 and E-7 illustrate 5-yeartrends in plutonium-239 and plutonium-240 release rates. Releases of these plutonium isotopes continue to be in the $\mu \mathrm{Ci}$ and sub$\mu \mathrm{Ci}$ range.

Uranium. Figures E-8 and E-9 depict 5-year trends in uranium-233,234 and uranium-238 release rates. Atmospheric releases of uranium are also on the sub- $\mu \mathrm{Ci}$ scale. Releases of uranium233, 234 to the Great Miami River, conversely, are comparable to the plutonium-238 release levels to the River. As seen in Figure E-9, the release rates have remained stable over the the 5-year period, and the $1991 \mathrm{AIL}$ has not been exceeded.

ENVIRONMENTAL MONITORING PROGRAM RESULTS

Besides setting limits on the CEDE to any member of the public from Mound operations, DOE has established DCGs for individual radionuclides. The Derived Concentration Guide is defined as the concentration of a radionuclide that will result in a CEDE of 100 mrem (1 mSv) following continuous exposure for one year. The concentrations of radionuclides from Mound's 1991 releases were small fractions of the appropriate DCGs. 




1991 ALARA Investigation Level $=30 \times 10^{-6}$ Curies

Figure E-4. Plutonium-238 releases from Mound to the atmosphere

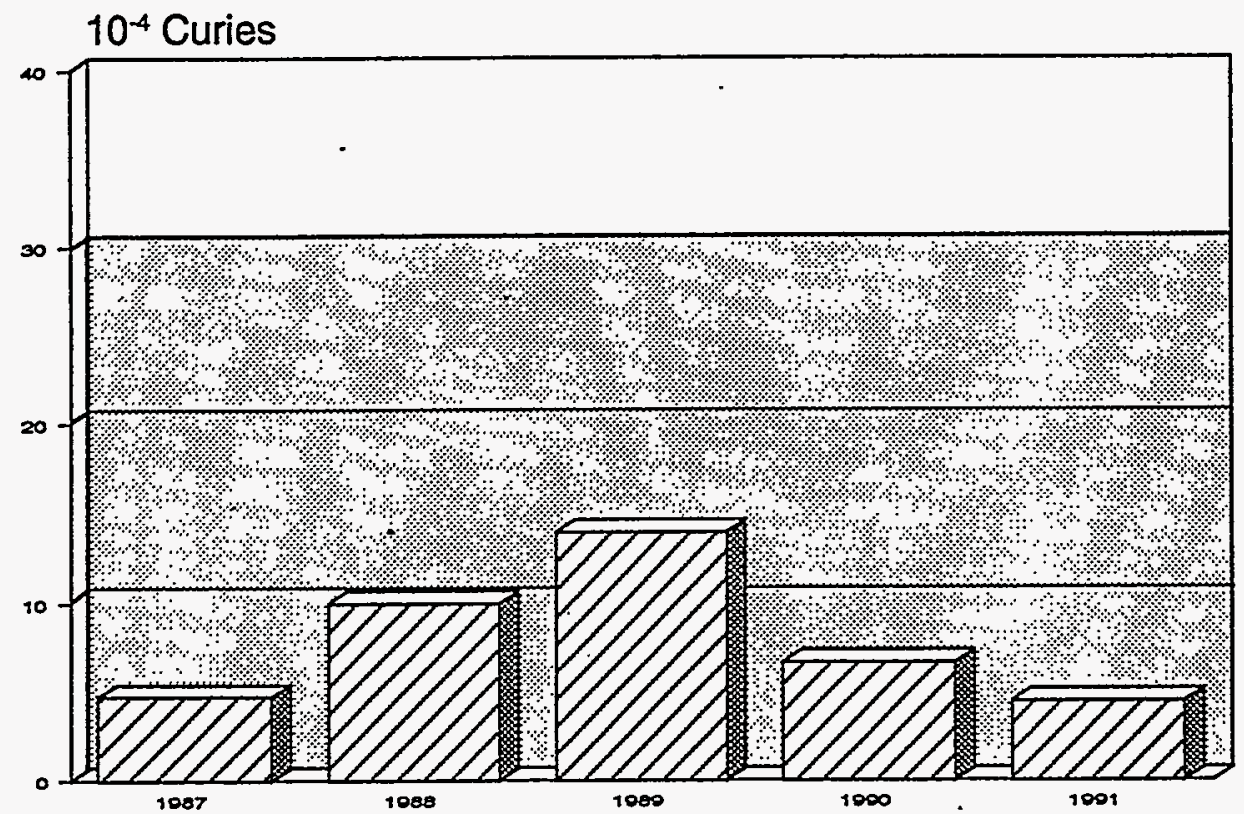

1991 ALARA Investigation Level $=30 \times 10^{-4}$ Curies

Figure E-5. Plutonium-238 releases from Mound to the Great Miami River 


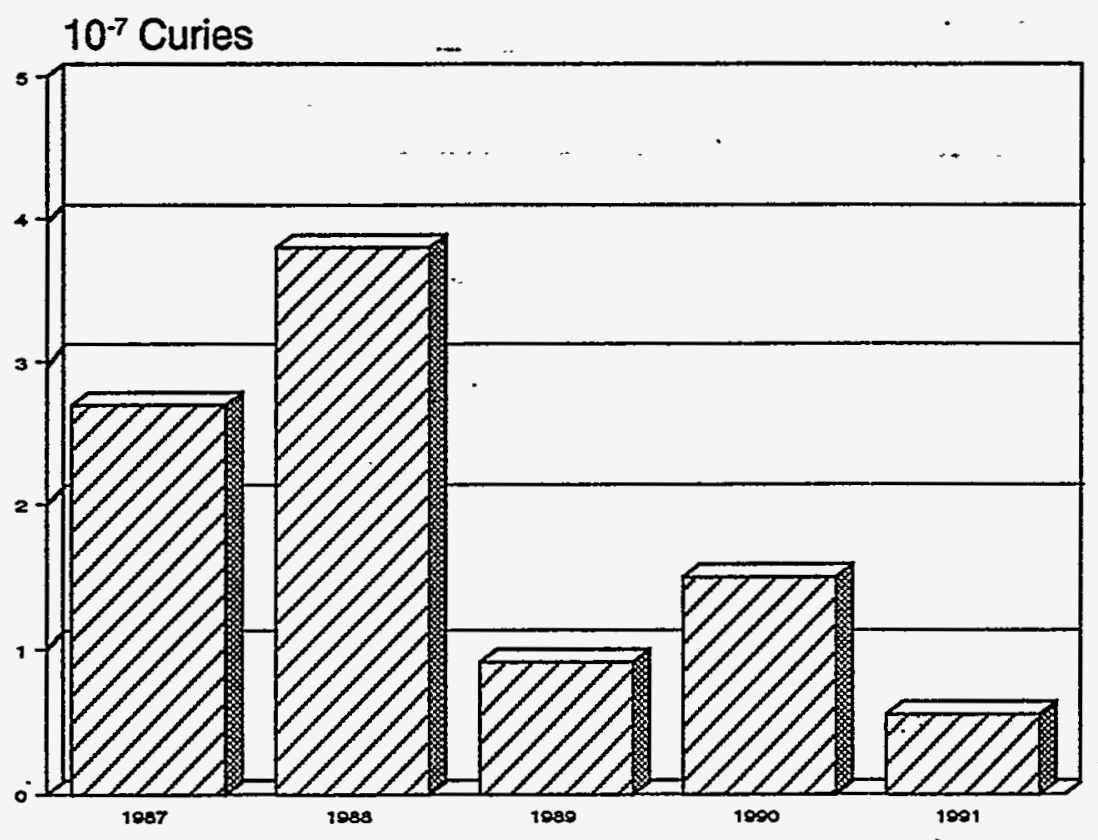

(Releases too low to warrant an All.)

Figure E-6. Plutonium-239,240 releases from Mound to the atmosphere



(Releases too low to warrant an AIL.)

Figure E-7. Plutonium-239,240 releases from Mound to the Great Miami River 


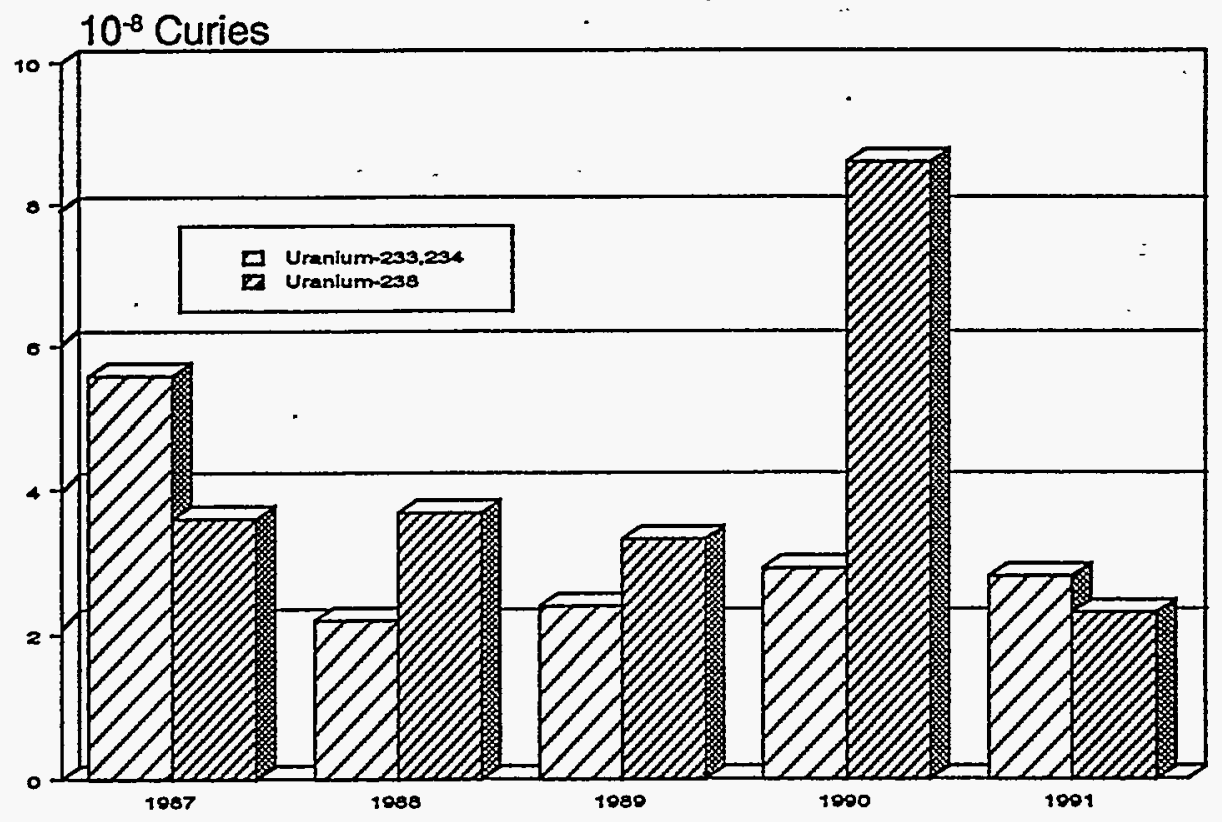

(Releases too low to warrant an AIL.)

Figure E-8. Uranium releases from Mound to the atmosphere



1991 ALARA Investigation Level $=10 \times 10^{-4}$ Curies

Figure E-9. Uranium-233,234 releases from Mound to the Great Miami River 


\section{Radiological Monitoring of the Atmosphere}

Ambient air is monitored for tritium and plutonium by an onsite network of 5 perimeter samplers and an offsite network of 15 samplers. Ten of the offsite samplers are located in the Miamisburg area. One sampler is located far enough away to receive virtually no impact from Mound operations. This sampler serves as a reference location to establish background levels of tritium and plutonium. The amount by which a sample exceeds the background or environmental level is reported as an incremental concentration.

The average incremental concentrations at the onsite samplers for plutonium-238 and tritium oxide were $0.05 \%$ and $0.02 \%$, respectively, of the DOE DCGs. Average incremental concentrations of plutonium-238 and tritium oxide at the offsite samplers were $0.006 \%$ and $0.004 \%$, respectively, of the DOE DCGs. Incremental concentrations of plutonium-239,240 measured onsite averaged $0.00001 \%$ of the DOE DCGs; offsite averages were below the environmental level.

\section{Radiological Monitoring of Water .}

Water samples were collected from locations along the banks of the Great Miami River and were analyzed for tritium, plutonium-238, uranium-233,234, and uranium-238. Other surface water locations were sampled for tritium and plutonium-238. Drinking water from the Miamisburg area was analyzed for tritium, plutonium238, uranium-233,234, and uranium-238. Silt samples were collected from the River and other surface water locations and analyzed for plutonium-238.
Surface water. The average incremental concentrations of tritium and plutonium-238 in the GreatMiami Riverwere $0.001 \%$ and $0.0002 \%$, respectively, of the DOE DCGs. The average concentration of uranium-233,234 was $0.0009 \%$ of the DOEDCG; average uranium-238 concentrations were below the environmental level.

Drinking water. DOE DCGs are intended to be applied at the point of release, not at the point of exposure. Therefore, DCGs are not applicable to drinking water sources. However, of the radionuclides routinely released by Mound, only tritium has a U.S. Environmental Protection Agency (EPA) drinking water standard (DWS). The other radionuclides released by Mound have not been assigned specific DWSs and are therefore evaluated below in terms of their respective DOE DCGs.

The average concentration of tritium in all private well samples was $9.4 \%$ of the EPA DWS. The average concentration of tritium in onsite well samples was $12.5 \%$ of the DWS. Plutonium238 concentrations in a private well and in Miamisburg city water averaged $0.02 \%$ of the DOE DCG. The average concentration of plutonium238 in onsite wells was $0.07 \%$ of the DOE DCG. Private well and Miamisburg city water exhibited uranium-233,234 and uranium-238 concentrations of $1.6 \%$ and $1.2 \%$ of the DOE DCGs, respectively. Onsite well concentrations of uranium233,234 and uranium-238 averaged $1.05 \%$ and $0.75 \%$, respectively, of the DOE DCGs.

Silt. A verage concentrations of plutonium238 in silt samples collected from the Great Miami River below Mound suggest some accumulation of Pu-238 relative to other sampling locations. However, at the very low concentration levels observed, the error limits are quite large and 
the potential risk from such concentrations is quite small.

\section{Radiological Monitoring of Foodstuffs and Vegetation}

Locally-grown foodstuffs, vegetation, and fish samples were collected from the surrounding area. These samples were then analyzed for tritium and/ or plutonium-238 as appropriate. Concentrations of tritium averaged $0.15 \times 10^{-6} \mu \mathrm{Ci} / \mathrm{g}$ and $0.12 \times$ $10^{-6} \mu \mathrm{Ci} / \mathrm{g}$ for grass and tomatoes, respectively. Plutonium-238 concentrations measured in grass and root crops did not exceed environmental levels. Plutonium-238 concentrations in fish averaged $0.03 \times 10^{-9} \mu \mathrm{Ci} / \mathrm{g}$.

\section{Nonradiological Monitoring of Air}

Particulate loadings are measured at all of the onsite and offsite air sampling locations. Particulate concentrations appeared to be independent of distance fromMound. This result suggests Mound exerts little or no influence on the levels of airborne particulates.

\section{Nonradiological Monitoring of Water}

Mound's nonradiological liquid discharges are regulated by a National Pollution Discharge Elimination System (NPDES) permit. In 1991, 1010 samples were collected to demonstrate compliance with the NPDES permit. No exceedances of permit limits were detected by any of the samples.

\section{GROUNDWATER MONITORING PRO-} GRAM - :

Samples from monitoring and production wells were analyzed for various constituents including volatile organics, semivolatiles, pesticides, polychlorinated biphenyls ( $\mathrm{PCBs}$ ), metals, inorganic cations and anions, and radionuclides. The monitoring data indicate that volatile organic compounds and tritium, respectively, are the primary nonradiological and radiological contaminants of concern.

\section{ENVIRONMENTAL RESTORATION PRO- GRAM}

In November of 1989 Mound was designated a Superfund site, i.e., placed on the National Priorities List under the Comprehensive Environmental Response, Compensation, and Liability Act (CERCLA). In accordance with that designation, a multi-year Remedial Investigation/Feasibility Study (RI/FS) is in progress. This RI/FS continues aDOEEnvironmentalRestoration(ER) program established in 1984 to identify, assess, and remediate DOE sites at which residual contamination presents a human health and/or environmental risk. The ER program at Mound includes the assessment and any remediation of contaminated soil and groundwater.

\section{ENVIRONMENTAL SURVEILLANCE QUALITY ASSURANCE.}

To ensure the reliability of environmental data, Mound maintains an Internal Quality Assurance Program that consists of running blanks, internal standards, and duplicate samples. Mound also 
participates in comparison exercises with external laboratories to further validate environmental results. Comparisons of Mound's performance with that of other laboratories are shown in Section 7 of this report. The close agreement between Mound and the external labs demonstrates that Mound's Environmental Monitoring Program generates reliable data. 


\section{INTRODUCTION}

\subsection{DESCRIPTION OF MOUND SITE AND OPERATIONS}

\subsubsection{Location}

The Mound facility, named after the Miamisburg Indian Mound adjacent to the site, comprises 120 buildings on 124 hectares ( 306 acres) of land in Miamisburg, Ohio, approximately $16 \mathrm{~km}$ (10 mi) southwest of Dayton (Figure 1-1). The Great Miami River, which flows southwest through the city of Miamisburg, dominates the geography of the five-county region surrounding Mound (Figure 1-2). The river valley is highly industrialized. The rest of the region is predominantly farmland, dotted with light industry and small communities.

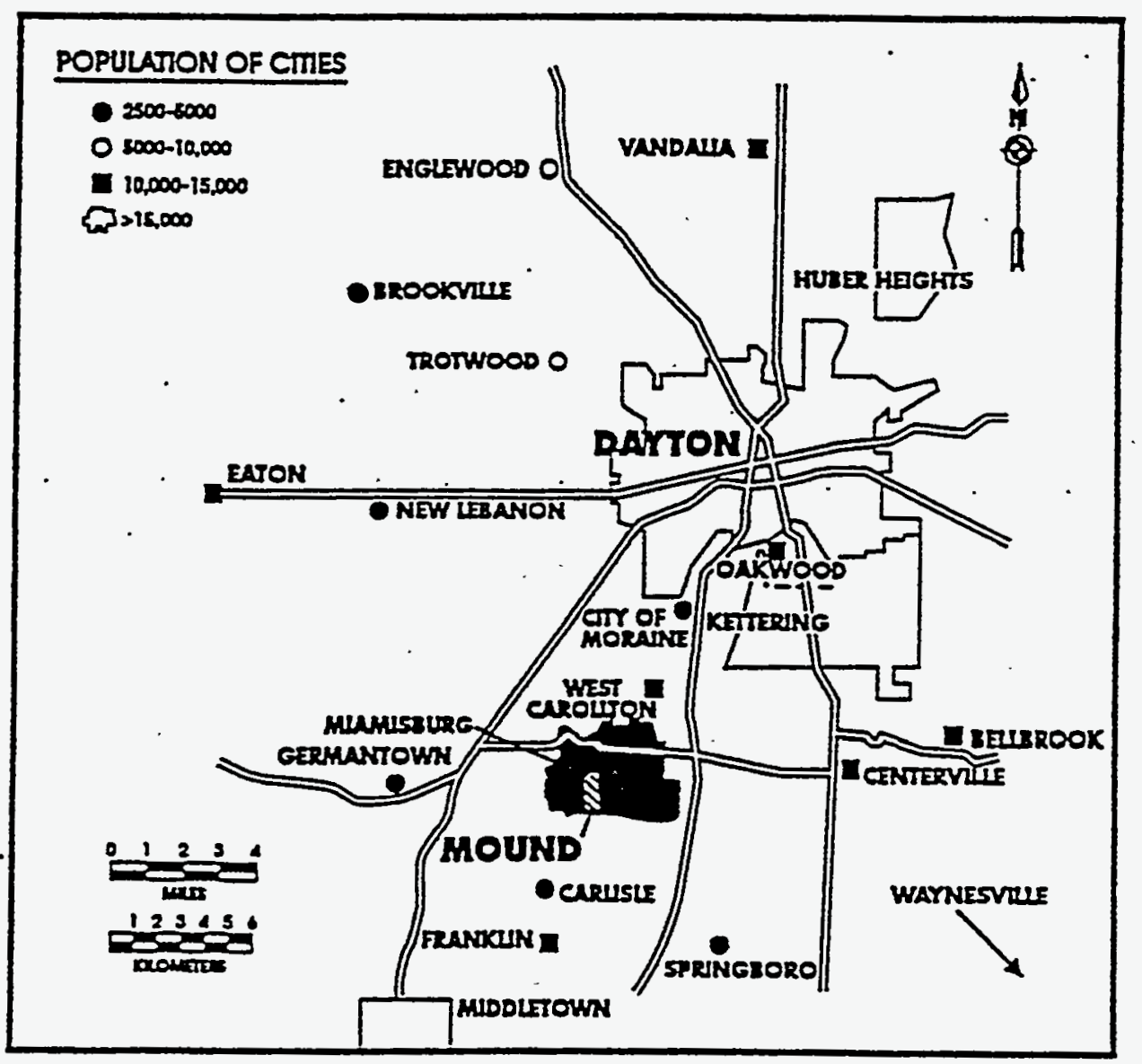

Figure 1-1. Locations of the Mound Plant and surrounding communities 


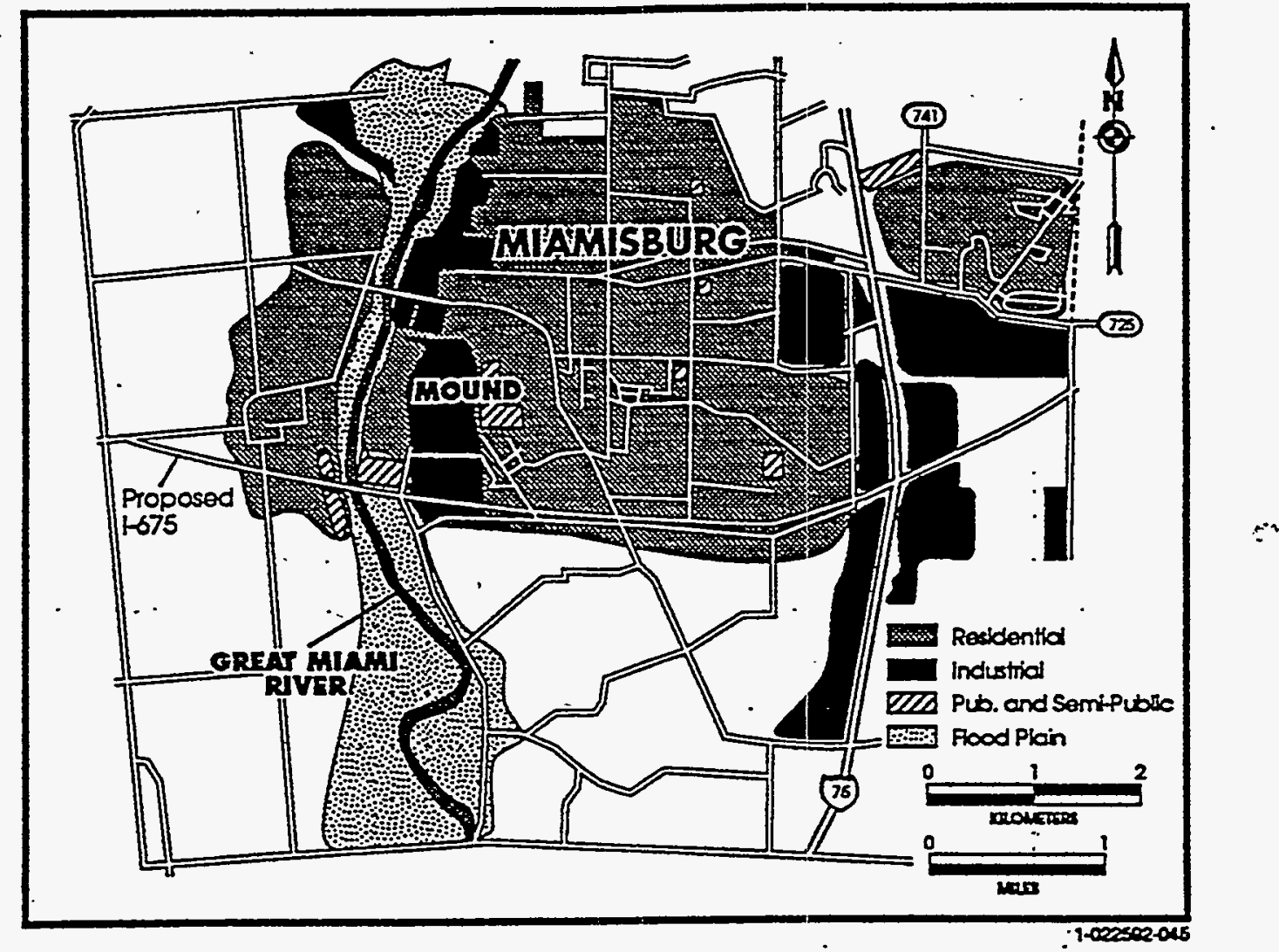

Figure 1-2. Location of Mound Plant

Figure 1-3 shows the population distribution within 50 miles $(80 \mathrm{~km})$ of Mound. The population information was extracted from 1990 Census data (PL94-171) by the Ohio Department of Development. The estimated number of individuals residing within the 50 -mile radius is $3,034,679$ (Table 1-2).

The primary agricultural activity in the area is raising field crops such as corn and soybeans. Approximately $10 \%$ of the agricultural land is devoted to pasturing livestock.
Table 1-1. Population Totals from the $\mathbf{1 9 9 0}$ Census

\begin{tabular}{cc}
\hline Radius, miles & Total \\
\hline $0-10$ & 322,876 \\
$0-20$ & 887,114 \\
$0-30$ & $1,477,621$ \\
$0-40$ & $2,541,609$ \\
$0-50$ & $3,034,679$ \\
\hline
\end{tabular}



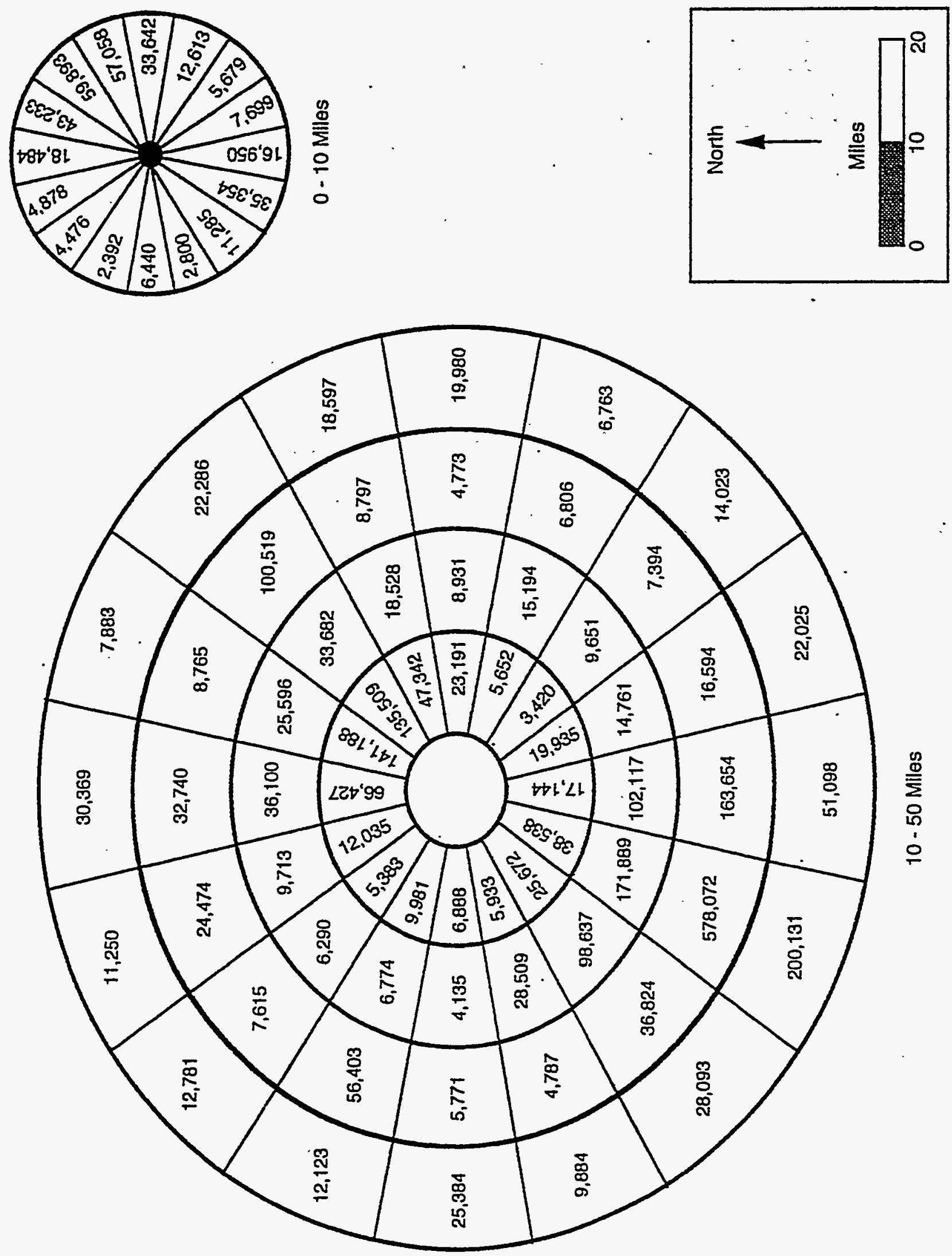

 
The climate is moderate. The average annual precipitation of $91 \mathrm{~cm}$ (36 in) is evenly distributed throughout the year (Figure 1-4). Total precipitation measured at Mound in 1991 was $79 \mathrm{~cm}$ (31 in). Winds are predominantly out of the south southwest (Figure 1-5). The annual average wind speed measured at Mound for 1991 was $4.9 \mathrm{~m} / \mathrm{s}$ (11.3 mi/hr) (Table 1-2).

The geologic record preserved in the rocks underlying Mound indicates that the area has been relatively stable since the beginning of the Paleozoic era more than 500 million years ago. No evidence indicates subsurface structural folding, significant stratigraphic thinning, or subsurface faulting in the Richmond beds, which are nearly horizontal. Nor is there evidence of sub-Richmond structural displacementin the immediatesurrounding area. Limestone strata, which are interbedded with protective shale layers at the site, show no evidence of solution activity. No evidence of solution cavities or cavern development has been observed in any borings or outcrops in the Miamisburg area.

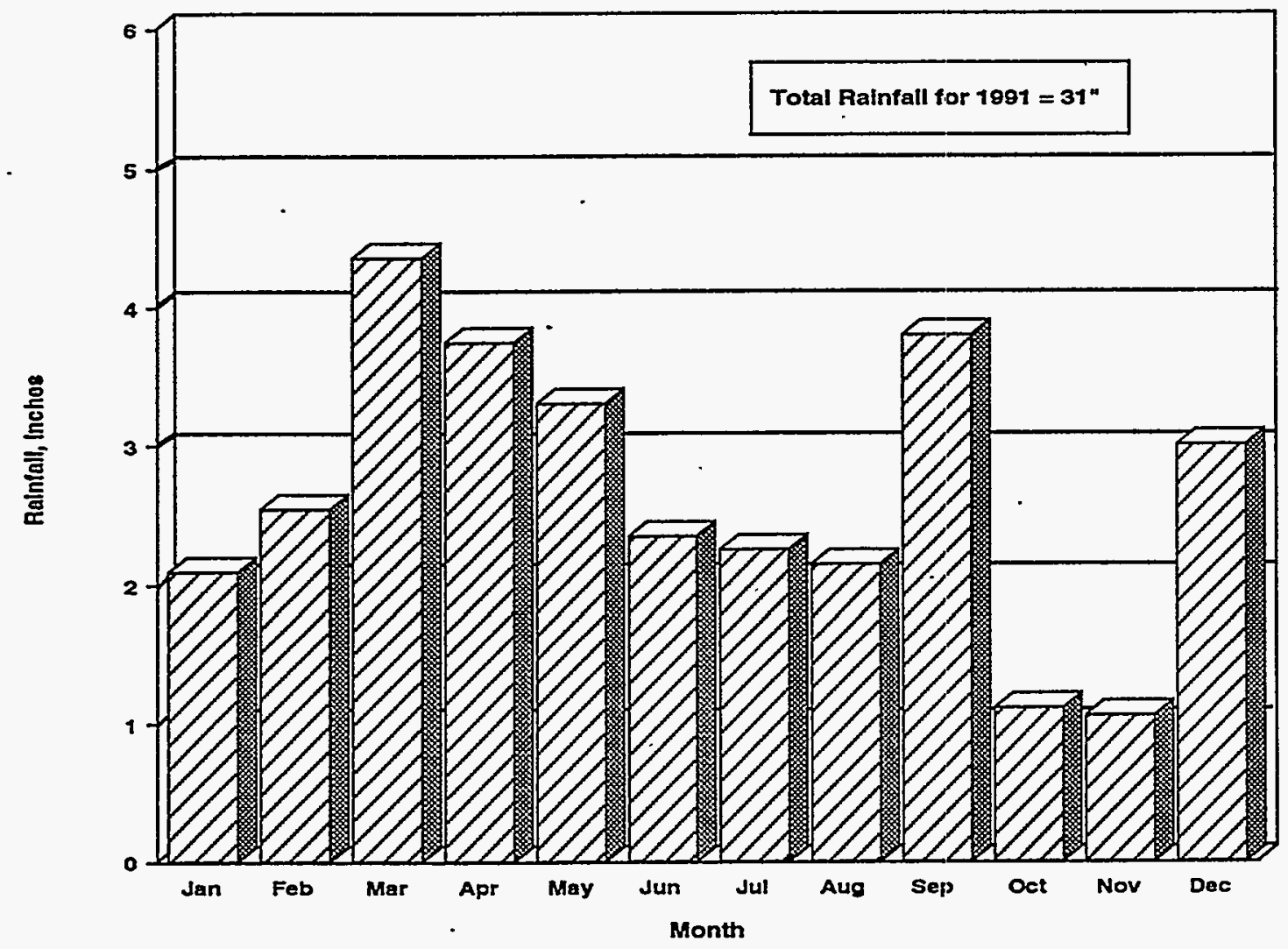

Figure 1-4. Monthly rainfall for 1991. 

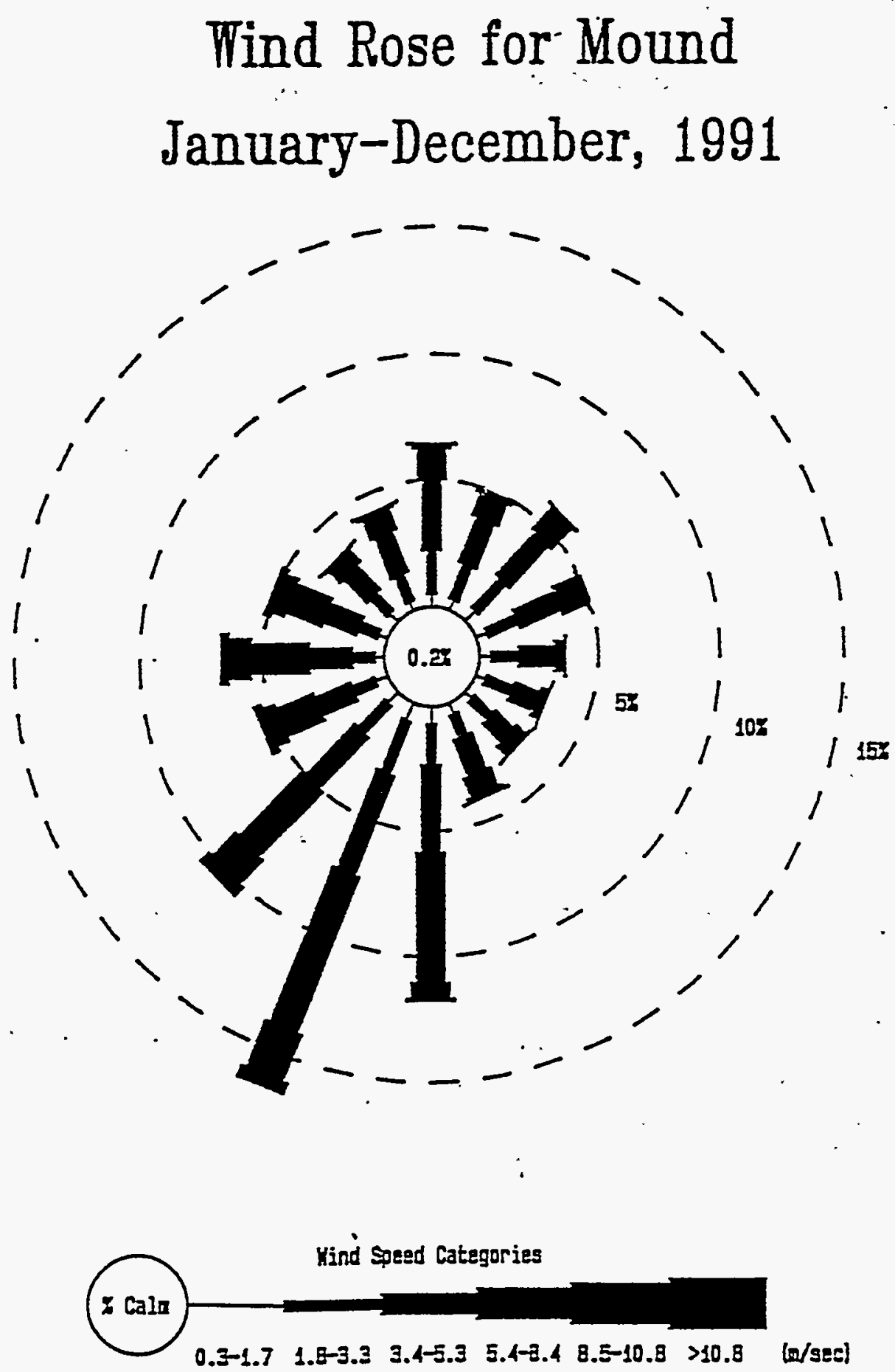

Data set is 99.53 somiete.

Figure 1-5. 1991 wind speeds and directions 


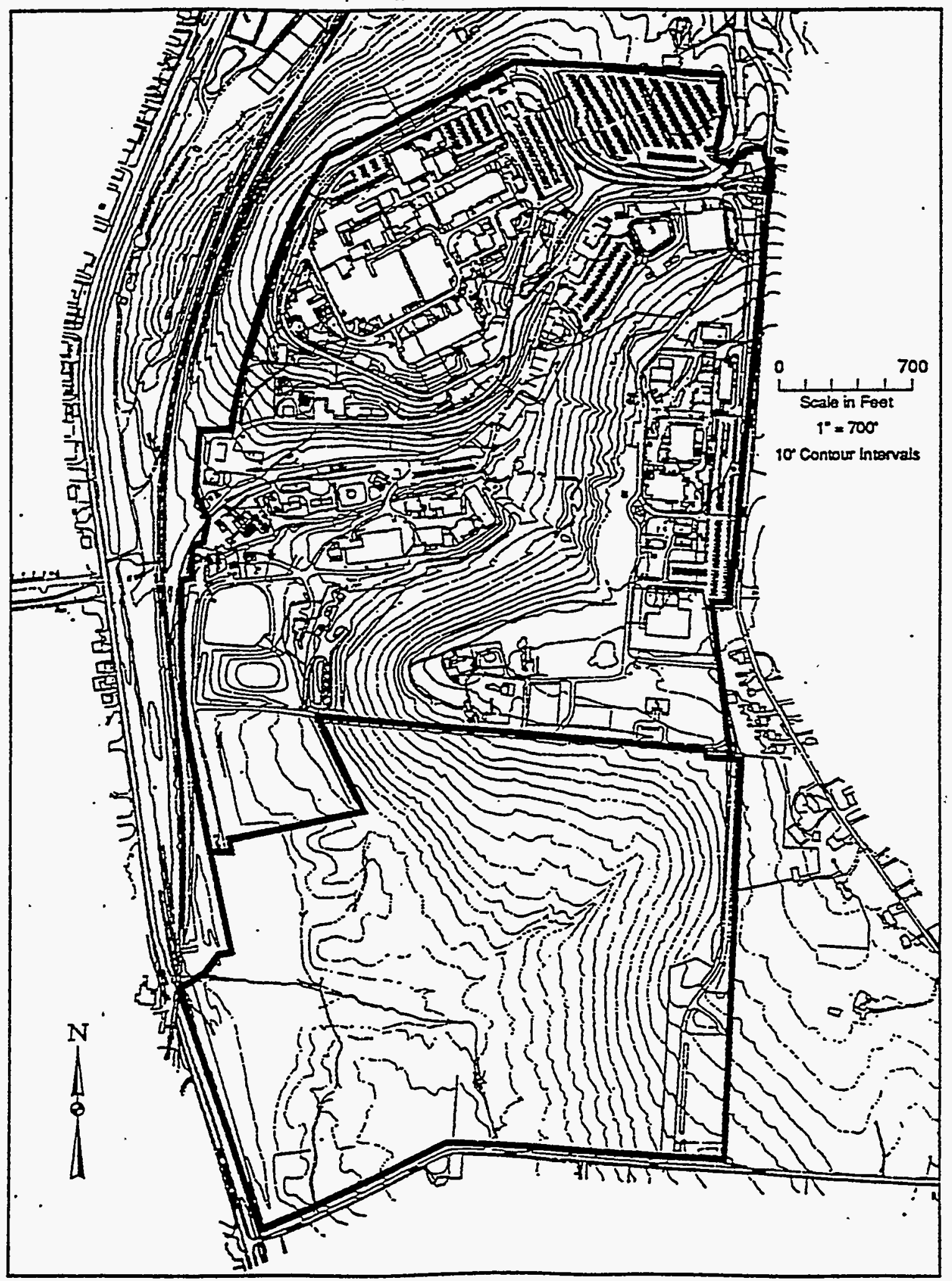

Figure 1-6. Mound site topography 


\subsection{PERSPECTIVE ON RADIATION}

This section attempts to put into perspective the potential consequences of the radionuclide releases described in subsequent sections of this report.

Most consequences to humans from radionuclides released to the environment are caused by interactions between radiations emitted by the nuclides and human tissue. These interactions involve the transfer of energy from the radiations to the tissue, a process that may damage the tissue. The radiations may come from radionuclides located outside the body (i.e., in or on environmental media and man-made objects) and from radionuclides deposited inside the body via inhalation, ingestion, or absorption through the skin. Exposures to radiations from nuclides located outside the body are called external exposures and will last only as long as the exposed person is near the external sources. Exposures to radiations from radionuclides deposited inside the body are called internal exposures and will last as long as the radionuclides remain in the body.

A number of specialized units are used to characterize exposures to ionizing radiations. Because the damage associated with such exposures is due primarily to the deposition of radiant energy in tissue, these units are described in terms of the amount of radiant energy absorbed by the tissue and the biological consequences of the absorbed energy. Some of these units are defined below.

- Absorbed dose indicates the amount of energy absorbed by a material (e.g., human tissue), divided by the mass of the material. The unit of absorbed dose is the gray (Gy) or the $\operatorname{rad}(100 \mathrm{rads}=1 \mathrm{~Gy})$.

- Dose equivalent indicates the biological effect of an absorbed dose on a particular organ or tissue. It equals the absorbed dose multiplied by factors that relate the absorbed dose to biological effects on that particular organ. The unit of dose equivalent is the sievert (Sv) or the rem $(100 \mathrm{rem}=1 \mathrm{~Sv})$.
- Effective dose equivalent indicates an individual's fatal cancer risk from an exposure to ionizing radiation. It is calculated from the weighted sum of the dose equivalents from the irradiated organs. It is also expressed in rems or Sieverts.

- Committed effective dose equivalent indicates the total dose over the individual's projected remaining lifetime (assumed to be 50 years) that results from an intake during 1 year. The committed effective dose equivalent (CEDE) expresses the dose of internal radiation received when an individual has ingested or inhaled a radionuclide that will

$\because$ remain inside the body for months or years. It is also expressed in rems, mrems $(1000 \mathrm{mrems}$ $=1 \mathrm{rem}$ ), or Sieverts.

- Collective committed effective dose equivalent indicates the sum of the committed effective dose equivalents to the individuals in a population. It gives an estimate of the expected health risk to the population from a dose of radiation. It can be used to calculate probable risks that might be too small to predict on the basis of a single individual. It is expressed in person-Sieverts or person-rems.

\section{Sources of Radiation}

Every day our bodies absorb ionizing radiation. Most of it comes from natural sources. Consumer products and medical procedures that use radiation are other common sources of ionizing radiation.

Natural Sources. Natural radiation comes from two sources-cosmic and terrestrial. Cosmic radiation results when energetic particles from outer space, traveling at nearly the speed of light, collide with nuclei in our atmosphere, creating radiation and showers of particles that fall to earth. The average annual dose equivalent received from cosmic radiation is 26 mrem $(0.26$ $\mathrm{mSv}$ ) for an individual living at sea level. Because cosmic radiation dissipates as it travels through 
the atmosphere, individuals living at lower altitudes receive less dose from this source than those living at higher altitudes.

Terrestrial radiation results when radionuclides that are a natural part of the earth's rocks and soils emit ionizing radiation. Because the concentrations of these radionuclides vary geographically, an individual's exposure depends on his location. The average annual dose equivalent from terrestrial radiation for an individual living in the U.S. is $28 \mathrm{mrem}(0.28 \mathrm{mSv})$.

Besides absorbing radiation from external radionuclides, we can also absorb radiation internally when we ingest radionuclides along with the food, milk, and water we ingest or along with the air we inhale. Once in our bodies, radionuclides follow the same metabolic paths as nonradioactive forms of the same elements. The length of time a particular radionuclide remains and emits radiation depends on whether the body eliminates it quickly or stores it for a long period, and on how long it takes for the radionuclide to decay into a nonradioactive form. Inhalation of radon contributes about 200 mrem ( $2.0 \mathrm{mSv}$ ) to the average annual dose equivalent from internal radiation. Other radionuclides contribute approximately 39 mrem (0.39 mSv).

Consumer Products. Many familiar consumer products emit ionizing radiation. Some must emit radiation to perform their functions, e.g., smoke detectors and airport x-ray baggage inspection systems. Other products, e.g., TV sets, emit radiation only incidentally to performing their functions. The average annual effective dose equivalent to an individual from consumer products ranges from 6 to $12 \mathrm{mrem}$ ( 0.06 to $0.12 \mathrm{mSv}$ ).

Medical Uses. Radiation is a tool for diagnosing and treating disease. The average annual dose equivalent for an individual in the U.S. from diagnostic radiation is $53 \mathrm{mrem}(0.53 \mathrm{mSv})$. Individuals undergoing radiation therapeutic procedures may receive much higher doses. 


\section{COMPLIANCE SUMMARY}

The Mound Plant must operate in compliance with environmental requirements established by federal and state statutes and regulations, Executive Orders, U.S. Department of Energy (DOE) Orders, and a Federal Facilities Agreement (FFA). Mound's status with respect to each of these requirements is summarized below.

\subsection{MAJORENVIRONMENTALSTATUTES}

\subsubsection{Clean Air Act (CAA)}

Radiological emissions. At Mound ten stacks discharge radioactive effluents to the environment. These sources are subject to the National Emission Standards for Hazardous Air Pollutants (NESHAPs) for radionuclides. The NESHAPs, radionuclides regulations (40CFR 61 , Subpart $\mathrm{H}$ ) are enforced by the U.S. Environmental Protection Agency (EPA). Throughout 1991, all Mound emissions were within required limits and no enforcement citations were received. The maximum committed EDE to an individual resulting from tritium and plutonium-238 released to the air was $0.14 \mathrm{mrem}(0.0014 \mathrm{mSv})$, which represents $1.4 \%$ of the NESHAPs EDE standard of 10 mrem per year $(0.1 \mathrm{mSv} / \mathrm{yr})$.

During a Federal Insecticide, Fungicide, and Rodenticide Act (FIFRA) inspection of Mound on September 17 - 19, 1991, the EPA inspector also reviewed Mound's activities relative to NESHAPs. Mound has not yet received a copy of the report from this inspection; however, during the close-out meeting the EPA inspector did not indicate any findings or issues requiring a Notice of Warning letter.

In November of 1991, a two-year plan to bring Mound's effluent monitoring hardware into full compliance with $40 \mathrm{CFR} 61$, Subpart $H$ was submitted to Region V of the U.S. EPA. Two staff members were added to the Environment and Waste Management Section of EG\&G Mound to implement this plan. If funding for project completion remains available, new compliance monitoring systems should be installed on all major radionuclide-emitting stacks by the fourth quarter of 1993.
Nonradiological emissions. Mound has six state air permits from the Ohio Environmental Protection Agency (OEPA). A number of other sources are registered with the Regional Air Pollution Control Agency (RAPCA). Throughout 1991, all emissions were within required limits (Table 5-1) and no enforcement citations were received.

A comprehensive survey of all emission points at Mound was conducted during 1991. The survey results led to the preparation of 138 additional permitapplications. These applications were submitted to RAPCA in the first quarter of 1992. Though it may be necessary for these emission sources to be registered with the State, it is not expected that many of them will require OEPA permits. It is also believed, based on an analysis of Mound's chemical inventories and usage rates, that the amounts of criteria pollutants, hazardous air pollutants, and ozone-depleting chemicals discharged by the Plant are below applicable regulatory thresholds.

\subsubsection{Clean Water Act}

The National Pollutant Discharge Elimination System (NPDES) permit issued to Mound requires compliance monitoring activities for four onsite discharges and one intermittent offsite discharge. In 1991, 1010 samples were collected for analysis. No exceedances were detected by NPDES monitoring.

While conducting the September 17 -19 FIFRA inspection, the EPA inspector also reviewed Mound's activities relative to the Clean Water Act. During the close-out meeting the EPA inspector did not indicate any findings or issues requiring a Notice of Warning letter. However, on March 26, 1992, a request was received for additional information on Mound's Spill Prevention Control and Countermeasures Program. 
OEPAperformed anNPDES inspection of Mound in April 1991 and was satisfied with the plant's NPDES monitoring program. On March 27, 1991, an application was submitted for renewal of the NPDES permit. It is anticipated that the permit will be reissued during the second quarter of 1992.

In 1991, as in previous years, Mound's Environmental Laboratory participated in a quality control program for laboratories performing NPDES analyses. In EPA-sponsored programs, labs analyze unknown control samples and submit the results for evaluation. Mound's lab was rated "acceptable", the highest rating issued, for all parameters measured.

i

\subsubsection{Safe Drinking Water Act (SDWA)}

Amendments to the SDWA have increased the compliance monitoring requirements for testing Mound's drinking water. Bacteriological testing is now performed monthly. Volatile Organic Compounds (VOCs) are monitored quarterly. These analyses must be performed by a statecertified laboratory: National Environmental Testing is the lab used to analyze Mound's drinking water for these parameters. In 1991, no violations of bacteria or VOC standards were detected by these measurements.

Mound experiences intermittent problems in meeting the minimum chlorination standard of $0.2 \mathrm{mg} / \mathrm{L}$ free chlorine at a limited number of drinking water fountains. Bacteriological testing of Mound's drinking water indicates that chlorine levels infrequently fall below the minimum standard and do not cause potability risks. Therefore, in 1990 Mound applied to the OEPA for an exemption from the chlorination standard. The Ohio EPA has not formally responded to Mound's request. Independent of OEPA's response, Mound Engineering has a system upgrade planned; the installation of a new water main for supplying the SM/PP tower is scheduled to begin in January of 1993. Once installed, all onsite water service will be provided by towers and short-term fluctuations in chlorine levels associated with chlorination equipment adjustments will be minimized.

\subsubsection{Resource Conservation and Recovery Act . (RCRA)}

The Mound Plant has interim status as a RCRA treatment and storage facility. Three hazardous waste storage units and three hazardous waste treatment units (glass melter, open burning of explosives, and explosives retorting) are maintained onsite. Operation of these units is addressed in the pending Part B application for the Plant. The permit application was first submitted in 1986. A series of resubmissions has been necessary to address technical issues and requests for additional information. A comprehensive revision of the Part $B$ application was submitted to OEPA on schedule in October of 1991.

OEPA and EPA inspected Mound's RCRArelated activities in 1991 . Several minor deficiencies, primarily of an interpretive nature, were noted. Mound promptly completed corrective actions.

During the FIFRA inspection of Mound on September 17 - 19, 1991, the EPA inspector also reviewed Mound's activities relative to RCRA. Mound has not yet received a copy of the report from this inspection; however, during the closeout meeting the EPA inspector did not indicate any findings or issues requiring a Notice of Warning letter.

Before shipment offsite, hazardous waste is stored onsite in interim status storage units. Additionally, a small quantity of mixed radioactive and hazardous waste is stored onsite pending the development of on- or offsite treatment or disposal options. One option under consideration is thermal treatment of these wastes using the glass melter. A trial burn plan has been submitted for this unit and is under review by the OEPA. Although this option may prove feasible, the thermal treatment process will not be implemented unless compliance with the National Environmental Policy Act can be demonstrated.

Mixed waste presents a unique compliance issue. Currently there are no treatment or disposal alternatives for such material. The only option at - this time is continued storage. Because of this limitation, Mound may be forced to store mixed 
waste in quantities, and/or for time periods, which exceed RCRA limits.

The volume of material at Mound requiring management as mixed RCRA waste increased substantially in 1991. This increase resulted from DOE's moratorium on shipment of RCRA waste originating in Radioactive Material Management Areas (RMMAs). Pursuant to the May 17, 1991, moratorium, "suspect" mixed waste cannot be shipped to commercial treatment and/or disposal facilities which do not possess an NRC license. Therefore, until the moratorium is lifted, Mound must store waste from RMMAs in the mixed waste storage facility.

In response to the moratorium, Mound submitted a moratorium procedures packet to $\mathrm{DOE}$ in November of 1991 . The transmittal included excerpts from Mound technical manuals which document the implementation of a formal process for the identification and tracking of suspect waste. The transmittal is undergoing review. A target date for lifting the ban has not yet been established.

Onsite treatment. During 1991, small quantities of explosives and pyrotechnics were treated onsite using the interim status treatment units described above: The remaining non-suspect hazardous wastes were shipped offsite for appropriate RCRA-permitted treatment and/or disposal.

Nonhazardous solid wastes. Nonhazardous solid wastes generated at Mound are disposed of in a nearby sanitary landfill that is licensed and permitted. The volume of materials requiring landfill disposal was significantly decreased in 1991 by Mound's recycling program for.paper, aluminum cans, and scrap metal.

Ohio Bureau of Underground Storage Tank Regulations (BUSTR). Efforts intensified in 1991 to achieve full compliance with BUSTR. A survey performed in 1991 verified that the seven underground storage tanks (USTs) subject to BUSTR were properly identified and in compliance with applicable requirements. During 1991, leak-tightness testing was performed on the USTs. No BUSTR-regulated removal or upgrade activities were conducted in 1991.
2.1.5 Comprehensive Environmental Response, Compensation, and Liability Act (CERCLA)

The Mound Plant was listed on the National Priorities List as a Superfund site on November 21, 1989. A Federal Facilities Agreemènt (FFA) between DOE and EPA followed on October 12, 1990. The Statement of Work for the FFA requires DOE to conduct sufficient work to characterize Mound in terms of all hazardous substances that potentially pose a threat to human health or the environment. The FFA further requires that areas warranting immediate cleanup be addressed as soon as practical. Preliminary assessments have not identified any conditions that require immediate corrective action. However, 125-potential release sites have been identified and grouped into operable units for further assessment.

In 1991, work plans for a number of operable units were developed. The work plan for Operable Unit 9 was submitted for regulatory review. The work plan for Operable Unit 3 was approved by the U.S. and Ohio EPAs.

No releases of reportable quantities of CERCLA-regulated materials occurred during 1991.

\subsubsection{Toxic Substances Control Act (TSCA)}

Mound does not generate TSCA waste streams on a regular basis. However, efforts continue at Mound to remove TSCA waste associated with previous practices. The two primary areas comprising this category of waste are polychlorinated biphenyls (PCBs) and nonfriable asbestos.

PCBs. In 1991, 56 drums of PCB-contaminated soil, debris, oil and water were shipped offsite to an EPA-approved facility for disposal. Also in 1991, Mound continued to replace transformers and capacitors containingPCBs. All such wastes are stored onsite in accordance with TSCA regulations before offsite shipment. All required records and logs are also maintained.

PCB waste removed from an RMMA is currently handled as TSCA mixed waste. As indicated above for RCRA mixed waste, no disposal options are currently available. In the interim, 
PCB mixed waste handled onsite will be stored in the mixed waste facility. Because of the restrictions on mixed waste disposal, such storage could exceed the TSCAlimit, which is one year from the initial date of storage.

Asbestos. The use of asbestos in pipes, panels, and as an additive to diallyl phthalate in parts production, has been discontinued at Mound. Residual asbestos has been handled and packaged in compliance with regulations and shipped offsite to an approved facility for disposal. Other asbestos removal projects began in 1991 in connection with building renovation activities. All such projects are carefully monitored by the Industrial Hygiene Section to ensure compliance with TSCA.

\subsubsection{Emergency Planning and Community Right-to-Know Act (SARA Title III)}

Title III of the Superfund Amendments and Reauthorization Act(SARA) requires annual submissions of hazardous chemical inventory and emission data for the previous calendar year. To meet the requirements of Sections 311 and 312 of Title III, for 1991 Mound reported storing and/or utilizingthree "extremely hazardous" and 12 "hazardous" substances in quantities subject to regulation under the Act. A review of Plant toxic chemical data for 1991 has verified that the site is not subject to the reporting requirements of Section 313 of the Act.

\subsubsection{Federal Insecticide, Fungicide, and Roden- ticide Act (FIFRA)}

EPA conducted a FIFRA inspection of Mound on September 17 - 19, 1991. Mound has not yet received a formal copy of the report from this inspection; however, during the close-out meeting the EPA inspector did not indicate any findings or issues requiring a Notice of Warning letter.

\subsubsection{National Environmental Policy Act (NEPA)}

NEPA requires that consideration is given to the potential environmental impacts of federal actions prior to the irretrievable commitment of resources. Numerous NEPA checklists and other related documents were prepared for Mound in 1991. One process, thermal treatment of mixed radioactive and hazardous waste, is undergoing a more formalizedNEPA review, an Environmental Assessment (EA). The final EA is not expected until later in 1992; however, preliminary indications are that a finding of no significant impact will be issued.

\subsubsection{National Historic Preservation Act (NHPA)}

In compliance with Section 110 of the NHPA, portions of the Miami-Erie Canal and a small undeveloped portion of the Plant were subjected to an archaeological survey to identify any undisturbed areas containing structures or items of cultural or historical interest. No significant findings were noted and no sites surveyed were eligible for the National Register of Historic Places.

\subsubsection{Endangered Species Act}

No endangered species have been identified on the Mound Plant at this time. Areas of habitat preferred by the Indiana Bat (Myotis sodalis) are present onsite though the bat itself has not been observed. If future activity has the potential to disturb those habitat areas, Mound will consult with the U.S. Fish and Wildlife Service and conduct a biological survey to confirm the bat is not present. Should the survey results suggest the presence of one or more bats, an assessment of the environmental impact of the planned activity will be conducted prior to project approval. 
2.1.12 Executive Order 11988, 'Floodplain Management"

The main plant at Mound is not located in a floodplain. Recent investigations indicate that lower plant areas around production wells may be in a 100-year floodplain. This finding would not affect main plant operations.

\subsubsection{Executive Order 11990, 'Protection of Wetlands"}

As studies are performed in association with the Plant's Environmental Restoration Program, it will be possible to define any wetlands areas that may exist on or near the site. This activity will require a multi-year effort to complete.

\subsection{OTHER KEY ENVIRONMENTAL COM- PLIANCE ISSUES}

\subsubsection{Tiger Team Action Plan}

Mound continues to make improvements recommended by the 1989 DOE Tiger Team audit in accordance with a Corrective Action Plan developed for the Plant. As of December 31, 1991, corrective actions had been completed for 42 of the 78 findings identified by the Team. Also as of that date, 27 findings were scheduled for completion; nine findings were overdue:

A supplement to the Corrective Action Plan is under development. This supplement indicates specific corrective actions that will be taken for each remaining finding. A draft version of the plan has been reviewed by DOE and is scheduled for implementation during the second quarter of 1992. Though not all corrective actions have yet been completed, it is important to note that the Tiger Team assessment identified no problems at Mound that warranted curtailment or cessation of operations.

\subsubsection{Pending Lawsuit}

A class action lawsuit was filed against the Monsanto Research Corporation (MRC) and EG\&G Mound Applied Technologies (EG\&G) on December 5, 1991. The lawsuit asserts that MRC and EG\&G (Mound's previous and current operating contractors, respectively) "engaged in a continuous course of negligent ... and unlawful conduct resulting in ... repeated discharges of both radioactive and nonradioactive hazardous substances ... into the environment surrounding the facility." The lawsuit further asserts that these actions were "concealed from the plaintiffs". Though 33 individuals are listed as plaintiffs, attorneys representing the plaintiffs are seeking class certification for all persons who were residents, property owners, or lessees of property within a 5-mile radius of the plant.

EG\&G Mound strongly believes this suit is. without merit. Release data for Mound have been published each year in publicly distributed documents. Further, the release data demonstrate the efforts taken by the Plant to operate within all applicable regulatory requirements and guidelines.

\subsection{HIGHLIGHTS FOR THE FIRST QUAR- TER OF 1992}

During the period January 1 through March 31, no exceedances of Mound's NPDES limits occurred. Airborne and liquid releases of radioactivity were below applicable ALARA Investigation Levels.

A number of key environmental milestones . were completed in the first quarter of 1992. Specific program elements included:

- The Remedial Investigation/Feasibility Study Operable Unit 9 Site-Wide Work Plan was submitted for final regulatory review. Approval of this plan will allow Mound to perform a comprehensive evaluation of potential contamination and contaminant transport within and beyond the plant boundary. 
- Draft versions of the Mixed Waste Quality Plan and the Environmental/WasteManagement Training Program were developed. These actions are important components of Mound's efforts to (1) identify and track suspect radioactive waste, and (2) handle such waste in accordance with all applicable regulations and guidelines.

- In February of 1992, Mound submitted a Waste Generator's Application to the Nevada Test Site (NTS). Submission of this application is required before low specific activity (LSA) waste may be shipped to NTS. In the application, Mound detailed the extensive tracking program to which LSA waste are subjected.

- Mound completed the Emergency and Hazardous Chemical Inventory forms required by SARA Title III in February. A set of site maps, colorcoded to indicate the locations of specific chemicals, was included with the report. This submission under the Emergency Planning and Community Right-to-Know Act (SARA Title III, Sections 311 and 312) is required of applicable facilities by March 1 of each year.

- Early in 1992, plans were formalized to replace Mound's pilot-scale, high-grade paper recycling program with a plant-wide program involving the recycling of nonhazardous items in addition to high-grade paper.

- Acomprehensive management plan forMound's active and inactive underground storage tanks (USTs) was submitted for regulatory approval in February. This program plan places all tank systems in one of three categories on the basis of usage and applicable regulations.

- In April of 1992, Mound's Environmental Monitoring Plan was approved. This Plan documents the effluent monitoring, environmental surveillance, and associated quality assurance programs in place at the Plant.

\subsection{SUMMARY OF PERMITS}

Mound operates in compliance with six state air permits and one NPDES permit (Table 3-3). Mound has filed an application with the OEPA for a site-wide RCRA permit covering all storage and treatment facilities. Also, in accordance with BUSTR requirements, three USTs are registered with the state; four additional USTs are otherwise regulated. 


\section{ENVIRONMENTAL PROGRAM INFORMATION}

\subsection{OVERVIEW OF ENVIRONMENTAL MONITORING PROGRAM}

The Mound Environmental Program monitors air, water, silt, vegetation, fish, and foodstuffs. Samples are collected from the environment up to $64 \mathrm{~km}$ (40 mi) from Mound's boundaries and are then analyzed for the specific radionuclides and nonradioactive substances processed by operations at Mound. Table 3-1 summarizes the monitoring program.

\subsubsection{Rationalefor Environmental Monitoring}

\section{Objectives}

The Mound Environmental Monitoring Program has for its primary objectives the following:

- To assess exposure, actual or potential, to the population from radioactive and nonradioactive materials from normal operations or accidents.

- To provide prompt and reliable information to, and effectively communicate with, government agencies and the public.

- To demonstrate compliance with standards.

- To check the effectiveness of facility containment operations.

- To warn of unusual or unforeseen conditions.

Additionnal objectives of environmental surveillance are: .

- To record continuously the effect of the site and its operations on the environment.

- To collect data on the concentrations of radioactive and nonradioactive substances in the air, water, soil, and biota to assess the shortand long-term effects of normal or accidental releases.
- To distinguish Mound's contributions from that of other sources.

- To advise of changing conditions so the program can be updated and revised in response to them.

- To provide data that will minimize uncertainties and thus enable more accurate predictions of risks to humans.

- To conduct studies to learn more about how radioactive and nonradioactive substances are transferred in the environment.

The following chapters describe how Mound's comprehensive Environmental Monitoring Program meets these objectives.

\section{Design of the Monitoring Program}

Four factors guide the design of the sampling operations that are part of the Environmental Monitoring Program: measurement, dispersion, accumulation, and potential risk to humans and the environment.

Measurement. The program is designed to maximize the efficiency and sensitivity of the measurements taken. Measurement at the source is the most efficient type of monitoring; therefore, the program provides continuous measurement of radioactive substances at their release points. A high level of monitoring capability is crucial to the . program. Mound's laboratory and field instruments, both at the emission source and in the environment, allow sensitive detection of most radioactive and nonradioactive substances.

Dispersion. The program is designed to concentrate sampling units in directions of predominant wind flow to enable reconstruction of exposures from inadvertent releases. 
Table 3-1. Summary of Mound's Monitoring Program

\begin{tabular}{llcl}
\hline & & Sampling Frequency & Parameter Measured \\
\hline Air Surveillance & & & \\
Offsite: & 14 locations & Weekly & HTO, Pu, particulates \\
Onsite: & 5 locations & Weekly & HTO, Pu, particulates \\
Stack Emission: & 10 locations & Daily & HT, HTO, Pu, U
\end{tabular}

Water Surveillance-Offsite

$\begin{array}{llll}\text { River: } & \begin{array}{l}\text { 5 locations } \\ \text { 5 locations }\end{array} & \begin{array}{c}\text { Weekly } \\ \text { Monthly }\end{array} & \text { HTO } \\ \text { Pond: } & \text { 7 locations } & \text { Quarterly } & \text { HTO, Pu, U } \\ \text { Municipal } & \text { 12 locations } & \text { Monthly } & \text { HTO } \\ \text { Drinking Water: } & \begin{array}{l}\text { Monthly } \\ \text { 1 location }\end{array} & \text { Monthly } & \text { Pu } \\ \text { Well Water: } & \text { 7 locations } & \text { Quarterly } & \text { Pu, U } \\ & \text { 2 locations } & & \end{array}$

Water Surveillance - Onsite

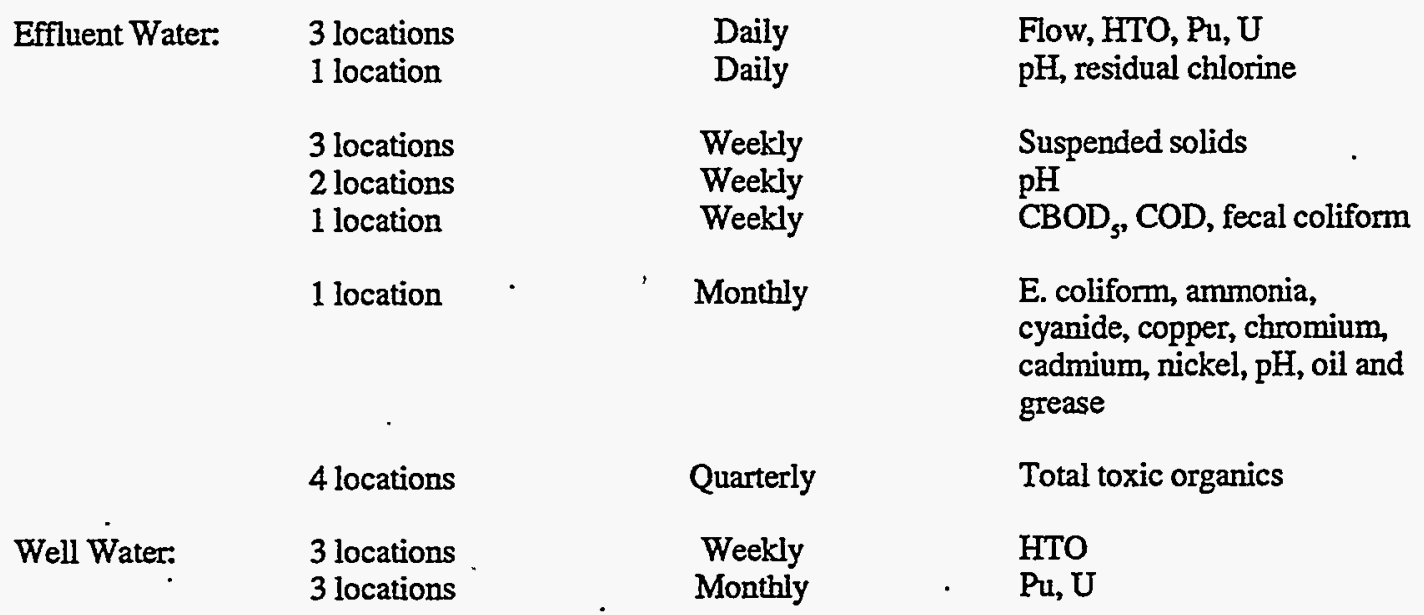

Silt Surveillance - Offsite

$\begin{array}{llll}\text { River: } & 5 \text { locations } & \text { Quarterly } & \mathrm{Pu} \\ \text { Pond: } & 6 \text { locations } & \text { Quarterly } & \mathrm{Pu}\end{array}$

Vegetation and Foodstuff Surveillance

$\begin{array}{llll}\text { Vegetation: } & 6 \text { locations } & \text { Annually } & \text { HTO, Pu } \\ \text { Foodstuffs: } & 6 \text { locations } & \text { Annually } & \text { HTO, Pu }\end{array}$

Environmental Level (Background) Surveillance
Five Media:
6 locations
Quarterly,
Monthly,
or Annually

Pu

Pu

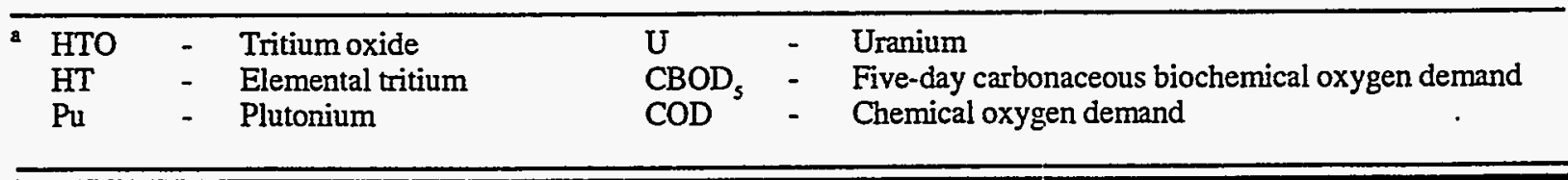


Accumulation. Many substances accumulate in specific compartments of the environment. The program monitors expected points of concentration to detect contaminants otherwise present in such low concentrations in the environment that they might go undetected.

Potential Risk. Monitoring of substances hazardous tohumans or the environment is given high priority. Other relatively innocuous substances may also be monitored because they are items of public concern.

Mound monitors those media in the environment that are most likely to contain the radionuclides of concern at Mound, tritium and plutonium-238. For example, to verify that plutonium238 concentrations comply with accepted standards for drinking water, Mound monitors community water supplies and well water. In addition, since plutonium-238 has a high affinity for soil and sediment, Mound analyzes silt and water in ponds and rivers. Bottom-feeding fish, e.g., carp, collected close to and downstream of Mound's - Great Miami River outfalls, are also analyzed.

The rationale for monitoring foodstuffs and vegetation is to sample readily available media that would most likely contain the radionuclides of primary concern at Mound. Grass is analyzed for both tritium and plutonium- 238 because it can take up these radionuclides from both air and soil. Root crops such as potatoes can take up plutonium-238 from the soil. Tomatoes, with theirhigh water content, are good indicators of uptake of tritium from air and soil.

The very small quantities of radionuclides other than plutonium-238 and tritium used at Mound are unlikely to pose any threat to the public or the environment. In cases where it is even remotely possible that these radionuclides could be found in more than insignificant quantities in the environment, they have been added to Mound's routine environmental monitoring program. Mound does not handle large quantities of uranium-233,234 or uranium-238. However, because uranium-234 is a decay product of plutonium-238, it has become a part of Mound's routine environmental monitoring program. Mound collects samples for uranium-233,234 in drinking water and in river water, where long-term decay and leaching could allow these uranium isotopes to become pollutants.

The design of the monitoring program is reviewed periodically, and if a rationale no longer exists for a certain measurement, it is deleted. Also, as necessary, the program is expanded to include new, state-of-the-art monitoring methods and new regulatory requirements.

\section{Calculation of Offsite Doses}

Data from the Environmental Program are used to calculate committed EDE to an individual and to the population as a whole in the Mound area. Because the doses are calculated rather than measured, they represent potential or estimated rather than actualdoses. The purposes of calculating offsite radiation doses to the public are to:

- assess continuously potential radiation exposures to the public,

- minimize risks,

- ensure public health,

- recognize and reflect public trust, and

- demonstrate that the protection of the public is a paramount concern.

\subsubsection{Determination of Environmental Con- centrations}

All concentrations of radionuclides are determined by subtracting the instrument background and reagent blanks from the sample count. The lower detection limit (LDL) is shown for each set of data in this report for comparative purposes and for single sample evaluation. The LDL is that value at which the presence of a contaminant, above that inherent in the detection method (including reagent blank), can be inferred at the $95 \%$ confidence level. It is calculated from the com- 
bined instrument and reagent blank backgrounds and their estimated standard deviation.

In addition to selecting sampling points along predicted dispersion pathways, points are selected at locations where discharges from the Mound facility would have no measurable impact. These locations are usually in a direction away from the prevailing winds and at a distance where virtually no impact would be measured. These are called "reference" or "background" locations. Sampling results from these locations are compared to those that may be affected by discharges from the Mound facility to determine the potential impact of the facility on the surrounding environment.
Concentrations measured at the reference location are called "environmental levels" in this report and previous years' reports. Environmental levels of radionuclides in various media as measured during 1991 by Mound are shown in Table 32. The average annual environmental level is subtracted frorn all onsite and offsite data except where noted. The concentration calculated from this difference, i.e., the incremental concentration, indicates the Mound facility's contribution to the environment. These concentrations are averaged for the year and then compared to either a DOE DCG or to a regulatory standard.

Table 3-2. Environmental (Reference) Concentrations of Radionuclides - in Various Media in 1991

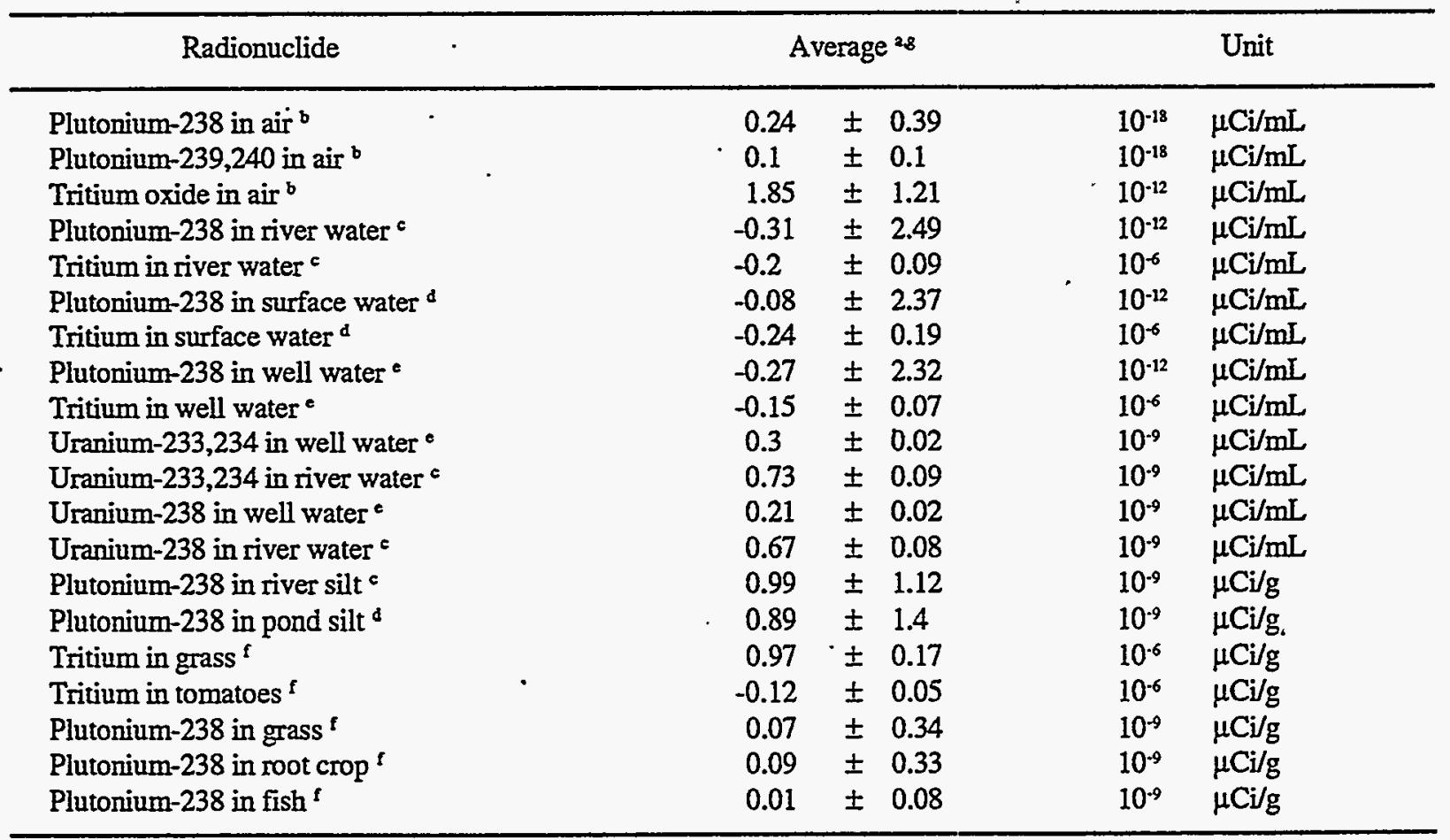

-Error limits are estimates of the standard error of the estimated means at the $95 \%$ confidence level.

${ }^{6}$ Measured at offsite sampler $119,44.8 \mathrm{~km}$ (28 mi) northwest of Mound.

'Measured $32 \mathrm{~km}$ (20 mi) upstream on the Great Miami River.

'Measured $61 \mathrm{~km}$ (38 mi) southeast of Mound.

- Measured $35 \mathrm{~km}$ (22 mi) southeast of Mound.

'Measured $64 \mathrm{~km}$ ( $40 \mathrm{mi}$ ) west of Mound.

${ }^{8}$ Negative values represent concentrations below the laboratory blank. 
The amounts of radionuclides being measured in the environment are small -most values in this report are expressed in microcuries $(\mu \mathrm{Ci} ; 1 \mathrm{Ci}=1$ million $\mu \mathrm{Ci}$ ). Such low concentrations, along with the statistical uncertainty inherent in measuring them, can result in negative values. Thus, negative values appear both in the environmental levels presented in Table 3-2 and in the concentrations of radionuclides reported from Mound's Environmental Monitoring Program. A negative or zero incremental concentration means that the concentration at the sampling location is equivalent to the environmental level and that there is no significant impact from the Mound facility.

In this report, tables of environmental monitoring results show the number of samples analyzed during the year, the minimum and maximum concentrations measured, the average value, the $95 \%$ confidence levels around the average, and a comparison (where appropriate) of the average with a DOE or regulatory standard expressed as a percent of the standard. The error limits shown with each table of data are estimates of the standard error of the estimated means at the 95\% confidence level. The values for the incremental concentrations include all sources of variability. including sampling, analyses, counting statistics, and the propagated error involved when the environmental levels (background levels) are subtracted from the values measured in the environment.

\subsection{OVERVIEW OF ENVIRONMENTAL ACTIVITIES}

\subsubsection{Effluent Treatment and Waste Manage- ment}

Effluent treatment. High efficiency particulate air (HEPA) filters remove particulate radionuclides from process air emissions. Air effluents are filtered first at their point of origin (i.e., the glovebox), and again just before reaching the release point (i.e., the stack). The filtering system in place at each stack is composed of two banks of HEPA filters placed in series. Each filter bank has a nominal collection efficiency of $99.95 \%$. Tritium is not trapped by HEPA filters; a chemical process is used to remove tritium from waste gas streams.

Waste management. An onsite sanitary waste treatment plant manages all domestic sewage generated onsite. An activated sludge process operated in the extended aeration mode provides the necessary treatment. The installation of a continuous backwash sand filter in 1986 essentially upgraded the plant to tertiary treatment. The influent and effluent at the sewage treatment plant are monitored for radioactivity to ensure that radionuclides are not inadvertently discharged to the environment.

All wastewater, after appropriate treatment and monitoring, is discharged from the plant to the Great Miami River. Digested sludge from the sewage plant is managed as low specific activity (LSA) radioactive waste. LSA wastes are currently being stored onsite pending acceptance of these wastes by the Nevada Test Site (NTS). NTS has established a rigorous waste certification protocol that must be followed before approval to ship the wastes is granted. Specific elements of the program include waste characterization, a plan for waste certification, standard operating procedures, QA policies, and an acceptable application to ship the wastes. Mound expects to receive approval of the "Mound Plant Application to Ship Waste to the Nevada Test Site" during 1992. All other solid low-level radioactive wastes generated at Mound are also stored onsite pending this approval.

Nonradioactive solid wastes are disposed of according to a recycling and reclamation program whenever possible. White paper, scrap metal, and wood are sold for reclamation. General refuse is transported to a sanitary landfill approved by the county and the state. Hazardous wastes are containerized, manifested, and moved offsite by a waste disposal firm for treatment and/or disposal using EPA-approved procedures. 


\subsubsection{Environmental Restoration Program}

The Mound Plant was designated as a Comprehensive Environmental Response, Compensation, and Liability Act (CERCLA) National Priorities List (i.e., Superfund) site in November 1989 (Environmental Protection Agency Administrative DocketNumber: V-W-'90-C-075). Pursuant to that designation, a multi-year program of remedial investigation/feasibility studies (RI/FSs) and remediation is in progress. The DOE Environmental Restoration Program (ER Program) was established in 1984 to identify, assess, and remediate DOE sites at which residual contamination presents a human health and/or environmental risk.

The ER Program includes the assessment and remediation of contaminated groundwater. The Mound Plant also has a Groundwater Protection Management Program (EG\&G March 1990) that was established pursuant to DOE Order 5400.1. The Groundwater Protection Management Program Plan recognizes that "until assessment and remediation, if any, is completed, the RI/FS will comprise the major portion of groundwater protection management at Mound Plant." Regarding annual reporting, the Program Plan states that:

\begin{abstract}
"During the completion of the ER Program a substantial amount of groundwater information and analytical data will be presented in ER Program reports, but will be referenced in the annual [environmental] report. However, some groundwater monitoring data will continue to be presented or summarized directly in the annual [environmental] report."
\end{abstract}

The ER Program report (EOE December 1990) completed in 1990 is a compendium of monitoring well geologic logs and contains a substantial amount of groundwater information. Also, an RI/ FS work plan for the Mound Plant was submitted to EPA and OEPA in April 1990 for comment and regulatory review. The work plan was exten- sively revised and submitted for final review in February 1992 (DOE February 1992). The plan contains a substantial discussion of prior groundwater monitoring.

In addition to the above references, and as directed by DOE Order 5400.1 , some groundwater monitoring data are presented or summarized in Section 6 of this report. The ER Program monitored groundwater elevations on a monthly basis from February through October. Those water level maps are included in the RI/FS Site-Wide Work Plan (DOE February 1992a).

The ER Program collected samples from monitoring wells for analysis of various constituents, including volatile organics; semivolatile organics or base, neutral, acid extractables (BNA); pesticides and PCBs; explosives; metals; inorganic cations; inorganic anions; and radionuclides. The sample collection dates and results of the analyses are included in a DOE technical memorandum (DOE February 1992b). -

The remedial investigation for Mound has been divided into nine operable units to facilitate the management of the program. To date Operable Unit 1 has been the focus of groundwater investigations and addresses identified contamination of groundwater by all contaminants. The interpretation of the 1990 groundwater sampling and analysis will culminate in a remedial investigation report for Operable Unit 1. Preliminary technical memoranda presenting the data were completed in 1991 (EG\&G April 1991).

Preliminary interpretation of the 1991 groundwatermonitoring data indicates that VOCs are the primary contaminants of concern. Most of the other analyses indicated either the absence of potential contaminants or the presence of naturally occurring substances within their expected normal concentrations.

\subsubsection{Self-Assessment Activities}

The Mound Plant is committed to continued improvement in the quantity and quality of reviews and audits performed for the Plant's environmental programs. During 1991, a Perform- 
ance Assurance Audit Group reviewed Mound's radioactive waste management, hazardous waste management, and environmental permitting programs. All three programs have been improved and expanded as a result of the audits.

In 1991, the ES\&H Department submitted the ES\&HSelf-AssessmentProgramPlan to DOE. A key element of this Plan is the Management Awareness Program. Monthly tours of work areas are required and must be fully documented. This approach provides an effective yet reasonably informal mechanism of addressing environmental concerns. Also as part of the Program, comprehensive checklists will be made available to the managers and supervisors to assist in the performance and documentation of the assessments.

\subsubsection{Waste Minimization/Pollution Preven- tion}

Mound has established a Waste Minimization/ Pollution Prevention Program to reduce the total volume and toxicity of Mound's radioactive, hazardous, radioactive mixed, and solid waste streams. These goals will be accomplished by preventing waste generation, by recycling and - reclamation, and, if appropriate, by treatment. The structure of the Program is detailed in Mound's Waste Minimization Plan, which is in final draft form and is expected to become an official Mound document in the near future.

To ensure effective facilitation and implementation of the Waste Minimization/Pollution Prevention Program, a Waste Minimization Committee was formed in August 1991. The initial task of the Committee was to ensure completion of two pilot process waste assessments by September 30 , 1991. The assessments have been completed as has a Process Waste Assessment Plan, which provides the basic format for characterizing waste sources to identify waste minimization and pollution prevention opportunities.

Specific activities underway in 1991 included a pilot-scale high-grade paper and aluminum can recycling program, and offsite recycling programs for halogenated solvents, oils, lead-acidbatteries, and scrap metals. Long-term goals for the programs are to continue to reduce waste generation, expand the nonhazardous waste recycling program, encourage the use of non-ozone-depleting chemicals and solvents, and to ensure employee awareness of these goals and the responsibilities they place on all personnel.

\subsubsection{Environmental Training}

Mound's environmental training activities continued in 1991. SARA, RCRA, and waste minimization training modules were presented to all appropriate employees. Other environmental training completed in 1991 included environmental laws, hazardous communication, NEPA compliance, RCRA compliance, waste certification issues, asbestos abatement certification; and ES\&H software quality assurance.

During 1991, specific emphasis was placed on Clean Air Act compliance. The legal counsel of Thomson, Hine and Flory was contracted by ES\&H to present permitting requirements for air emission sources. Based on those presentations, appropriate building managers and process operators were advised of federal and state permitting requirements. This training was provided to ensure that the permit applications submitted to RAPCA represented a comprehensive listing of all appropriate emission sources.

\subsubsection{Review of Monitoring Practices}

A comprehensive review of the radiological effluent and environmental monitoring practices in use at Mound was conducted in 1991 (Bauer May 1991). Emphasis was placed on potential expansions of the programs and on the role of resuspension at the Plant. The radionuclides considered included tritium (elemental), plutonium239,240 , uranium-233,234, uranium-238, thorium-230, thorium-232, cobalt-60, cesium-137, and actinium-227. Dose contributions from these radionuclides were found to be negligible. Consequently, it was concluded from the study that additional continuous monitoring programs were not warranted at this time. 


\subsubsection{Environmental Permits}

Mound operates in compliance with six state air permits and one NPDES permit. Additionally, Mound'shazardous waste program operates under RCRA interim status. A revised RCRA Part B application was submitted to OEPA in October of 1991 (Table 3-3).

Table 3-3. Environmental Permits Issued to Mound

\begin{tabular}{|c|c|c|c|}
\hline - Operation & Permit No. & Valid Through & Issuing Agency \\
\hline Paint spray booth & $0857091196 \mathrm{~K} 001$ & $09 / 22 / 92$ & OEPA \\
\hline $\begin{array}{l}\text { Open-top vapor } \\
\text { degreaser }\end{array}$ & $0857091196 \mathrm{~L} 001$ & $01 / 26 / 93$ & OEPA \\
\hline $\begin{array}{l}\text { Open-top vapor } \\
\text { degreaser }\end{array}$ & $0857091196 \mathrm{~L} 002$ & $01 / 26 / 93$ & OEPA \\
\hline Asbestos-filled DAP & 0857091196P006 & $06 / 01 / 92$ & OEPA \\
\hline $\begin{array}{c}\text { Open burning } \\
\text { (explosives disposal) }\end{array}$ & $\begin{array}{c}\text { N/A } \\
\text { letter permit }\end{array}$ & $10 / 29 / 92$ & OEPA \\
\hline $\begin{array}{c}\text { Open burning } \\
\text { (firefighter training) }\end{array}$ & $\begin{array}{c}\mathrm{N} / \mathrm{A} \\
\text { letter permit }\end{array}$ & $10 / 29 / 92$ & OEPA \\
\hline $\begin{array}{l}\text { Wastewater discharge } \\
\cdot \quad \text { (NPDES) }\end{array}$ & NP1-I-000005CD & $10 / 01 / 91^{a}$ & OEPA \\
\hline $\begin{array}{l}\text { Hazardous waste } \\
\text { operations (RCRA) }\end{array}$ & interim status & $N / A^{b}$ & OEPA \\
\hline
\end{tabular}

'The NPDES permit renewal application was submitted to OEPA on March 27, 1991.

${ }^{b}$ The Mound Facility is operating under interim status. The revised RCRA Part B application was submitted to OEPA on October 11, 1991. 


\section{ENVIRONMENTAL RADIOLOGICAL PROGRAM INFORMATION}

Summary: Air was sampled at a network of onsite and offsite locations. Samples were analyzed for tritium oxide, plutonium-238, and plutonium-239,240. Concentrations of these radionuclides were well within applicable limits. Drinking water samples were collected from onsite wells, Miamisburg city water, and from private wells. These samples were analyzed for tritium, plutonium-238, and uranium-233,234. Additional drinking water samples were collected at select locations. Drinking water samples from regional communities were analyzed for tritium; onsite well waters were tested for uranium-238. All values measured in these analyses were well within the applicable DOE DCGs or EPA standards. Water and silt samples were collected from the Great Miami River. Water samples were analyzed for tritium, plutonium-238, uranium233,234, and uranium-238; silt samples were evaluated for plutonium-238. Water and silt samples were also collected from other surface water locations in the area. The water samples were analyzed for tritium and pluntonium-238; the silt samples for plutonium-238. An additional component of Mound's radiological monitoring program is the collection of regional foodstuffs and vegetation samples. These samples were analyzed for tritium and/or plutonium238.

\subsection{AIR MONITORING PROGRAM}

\subsubsection{Description of Monitoring Program}

\section{1:1.1 Effluent Monitoring}

Stacks that release radioactive materials at Mound are sampled continuously. Those areas in which a potential for unplanned releases exists are also monitored continuously with alarm systems.

Tritium. In operational areas where a release potential exists, air in laboratories, storage areas, and ventilation exhaust stacks serving these areas is continuously monitored for tritium by ionization chambers that incorporate alarm systems. If a release occurs, these systems are designed to locate the source. In most situations, an effluent removal system and effluent containment system prevent or reduce the release of tritium to the atmosphere.

Plutonium. In operational areas where a release potential exists, ventilation air passes through a minimum of two HEPA filters before discharge through the stack to the atmosphere. Fixed continuous air samplers and continuous air monitors with alarm systems are used throughout the work areas to detect airborne plutonium. These monitoring systems have been designed to ensure that corrective action can be taken to prevent or reduce the release of plutonium to the atmosphere.

\subsubsection{Environmental Surveillance}

Onsite. A perimeter network consisting of five continuously operating, high-volume air samplers is used to assess further the effectiveness of stack emission control systems. The locations of the onsite samplers are shown in Figure 4-1.

Offsite. The offsite air-sampling network (Figure 4-2) consists of 15 continuously operating, high-volume air-sampling stations. Ten sampling stations are located within a $2.6 \mathrm{~km}(1.6 \mathrm{mi})$ radius of Mound. The distribution of these samplers is based on the maximum concentration predicted by a diffusion model developed for Mound (Eimutis and Mote, 1976). The samplers are distributed circumferentially around the site with a preponderance in the prevailing wind direction; i.e., the northeast quadrant. Four samplers are located in or adjacent to population centers (108, 110,111 , and 115). The remaining sampler (119) is approximately $44.8 \mathrm{~km}(28 \mathrm{mi})$ from Mound in the least prevalent wind direction. This sampler receives no measurable contribution from Mound operations and is used to calculate environmental levels. The average annual radionuclide concentrations from sampler 119 are subtracted from concentrations detected at other locations. The resultant values reflect Mound's contribution and are reported as "incremental" concentrations. 


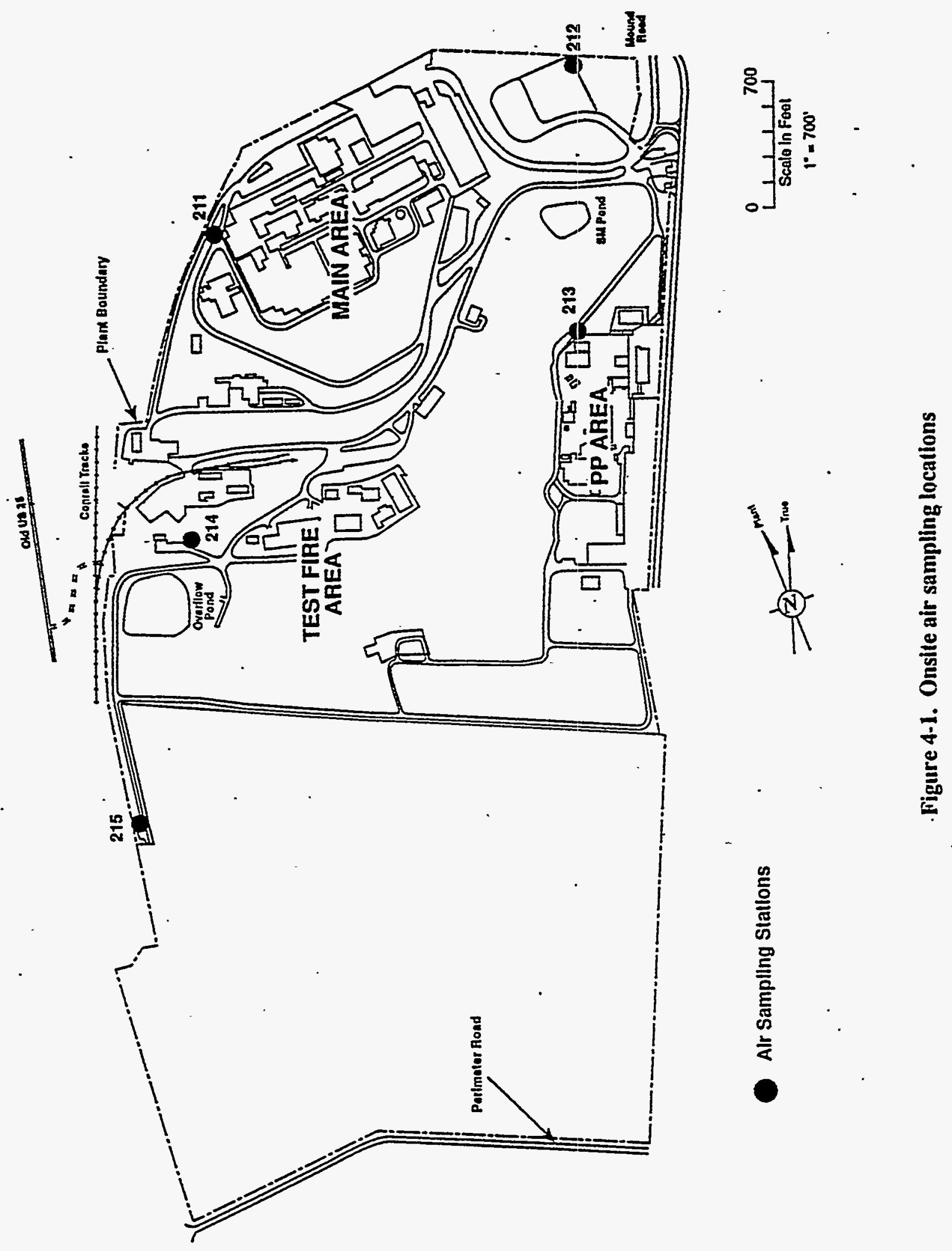




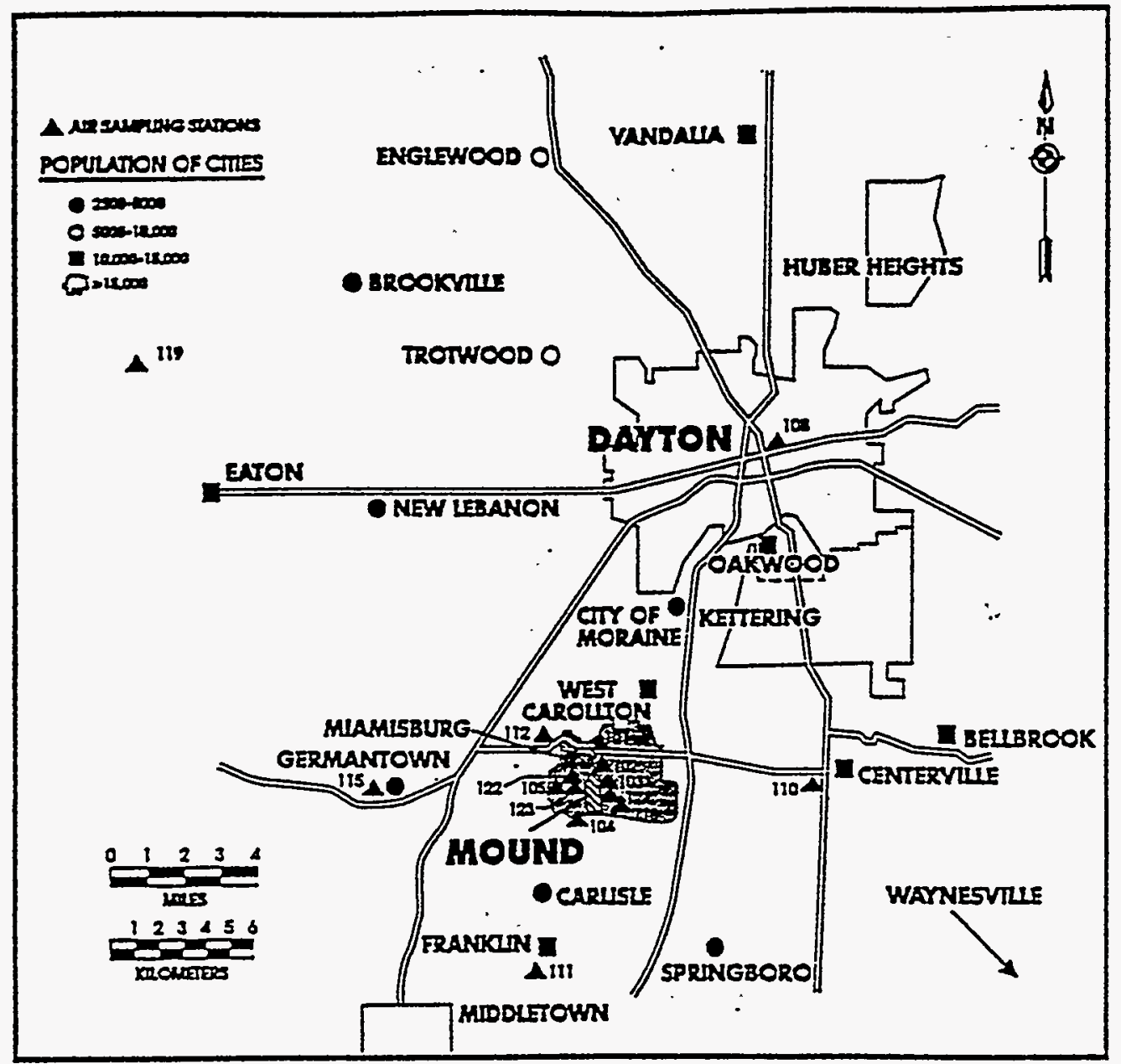

Figure 4-2. Offsite air sampling locations

Operation. Two types of samples are collected at each sampling station. A particulate air sample is analyzed for plutonium-238 and plutonium-239,240. A second sample, collected from a bubbler sampler, is analyzed for tritium oxide.

To monitor tritium and plutonium in offsite air, Mound has a contract with the Regional Air Pollution Control Agency (RAPCA). RAPCA collects the samples from Mound's offsite samplers, changes the filter papers and bubblers, and maintains and calibrates the samplers. RAPCA then delivers the samples to Mound for analysis. For the onsite samples, Mound personnel are used to perform these tasks.

The particulate sample for isotopic plutonium analysis is collected on a 200 -mm diameter fiber- glass disk by a continuously operating ( $24 \mathrm{hr} / \mathrm{day}$, 7 days/week) high-volume air sampler. The air is sampled at an average rate of $1.3 \times 10^{6} \mathrm{~cm}^{3} / \mathrm{min}$ (45 $\mathrm{ft}^{3} / \mathrm{min}$ ). The disk is changed weekly and represents a sample of approximately $13,000 \mathrm{~m}^{3}$ of air. Individual sample flow rates are used to calculate concentrations ateach location. Plutonium analyses are performed on a monthly composite for three sampling locations (122, 123, and 124), and on quarterly composites for the other offsite locations. The analytical scheme for plutonium incorporates the following basic steps: use of an internal tracer, chemical treatment, separation of plutonium with anion exchange resin, and alpha spectrometry. 
$\because$

The gas bubbler sample for tritium oxide analysis is also collected on a continuous basis by bubbling air at approximately $3 \times 10^{3} \mathrm{~cm}^{3} / \mathrm{min}$ through $200 \mathrm{~mL}$ of ethylene glycol. Ethylene glycol is used because it eliminates the evaporation and freezing problems associated with sample collection (Sheehan etal., 1975). Tritium oxide in the air collects in the solution. A sample representing $30 \mathrm{~m}^{3}$ of air is collected, and an aliquot representing $0.6 \mathrm{~m}^{3}$ is counted in a liquid scintillation spectrometer.

Tritium oxide rather than elemental tritium is sampled and analyzed because the dose that would result from a given release of tritium oxide would be 25,000 times greater than from the same release of elemental tritium.

\subsubsection{Applicable Standards .}

The guides for concentrations of radionuclides in air are given in DOE Order 5400.5. These guides are based on recommendations in Publications 26 and 30 of the International Commission on Radiological Protection (1977; 1979). The guides for radioactive concentrations are designated as DCGs. The DCG for a radionuclide is defined as the concentration of that radionuclide that will give a 50-year committed EDE of 100 mrem (1.0 mSv) if taken into the body through ingested water or inhaled air.

The revised DOE standards also include the EPA National Emission Standards for Hazardous Air Pollutants (NESHAPs), "Standards for Radionuclides (40 CFR 61, Subpart H)," which apply to DOE facilities. The NESHAPs standards state that radioactive air emissions shall not result in an EDE greater than $10 \mathrm{mrem}(0.1 \mathrm{mSv})$ per year to any member of the public.

\subsubsection{Results}

Stack emissions during 1991 contained 1232 $\mathrm{Ci}$ of tritium, $1.5 \times 10^{-5} \mathrm{Ci}$ of plutonium-238, 5.5 $\times 10^{-8} \mathrm{Ci}$ of plutonium-239,240,2.8 $\times 10^{-8} \mathrm{Ci}$ of uranium-233,234 and $2.3 \times 10^{-8} \mathrm{Ci}$ of uranium-238 (Table E-1). For uranium-233,234 and uranium238 emissions were $5.8 \times 10^{-9}$ and $1.1 \times 10^{-4} \mathrm{pg} / \mathrm{mL}$, respectively.

The 1991 emissions can be compared to the 5year trend data presented in Figures E-2 to E-9. Tritium ranged from a high in 1989 of $41,534 \mathrm{Ci}$ (due to an accidental release) to the 1991 low of $1,232 \mathrm{Ci}$. Plutonium-238 ranged from $3.5 \times 10^{-6} \mathrm{Ci}$ in 1989 to $1.8 \times 10^{-5} \mathrm{Ci}$ in 1990 , and plutonium239,240 from $3.8 \times 10^{-7} \mathrm{Ci}$ in 1988 to the 1991 low of $5.5 \times 10^{-8} \mathrm{C}$. . Uranium-233,234 ranged from $5.6 \times 10^{-8} \mathrm{Ci}$ in 1987 to $2.2 \times 10^{-8} \mathrm{Ci}$ in 1988 . None of the 1991 values represent an increase in the 5year trends, and two values represent 5-year lows.

Concentrations of tritium, plutonium-238, and plutonium-239,240 measured at offsite and onsite locations are shown in Tables 4-1 through 4-3. Because the stack emissions of uranium-233,234 and uranium-238 are so low and their contributions to the dose are negligible, these radionuclides are not monitored at the air sampling locations.

Concentrations of plutonium-238 at offsite locations ranged from below the environmental level to $50.58 \times 10^{-18} \mu \mathrm{Ci} / \mathrm{mL}$ (Table 4-1). The average incremental offsite plutonium-238 air concentration for all locations was $1.68 \times 10^{-18}$ $\mu \mathrm{Ci} / \mathrm{mL}$, which is $0.006 \%$ of the DOE DCG. Plutonium-238 concentrations onsite ranged from 1.2 to $69.36 \times 10^{-18} \mu \mathrm{Ci} / \mathrm{mL}$ (Table 4-1). The average incremental plutonium-238 concentration measured for all onsite locations was $13.88 \mathrm{x}$ $10^{-18} \mu \mathrm{Ci} / \mathrm{mL}$, which is $0.05 \%$ of the DOE DCG.

Offsite concentrations of tritium oxide ranged from below the environmental level to $74.37 \mathrm{x}$ $10^{-12} \mu \mathrm{Ci} / \mathrm{mL}$ (Table 4-2). The average incremental concentration of tritium oxide measured for all offsite locations was $4.32 \times 10^{-12} \mu \mathrm{Ci} / \mathrm{mL}$. This concentration is $0.004 \%$ of the DOE DCG. Onsite tritium oxide concentrations ranged from below the environmental level to $112.61 \times 10^{-12}$ $\mu \mathrm{Ci} / \mathrm{mL}$ (Table 4-2). The average incremental concentration of tritium oxide in air at onsite sampling locations was $15.95 \times 10^{-12} \mu \mathrm{Ci} / \mathrm{mL}$, representing $0.02 \%$ of the DOE DCG. 
Concentrations of plutonium-239,240 measured at offsite locations ranged from below the environmental level to $0.33 \times 10^{-18} \mu \mathrm{Ci} / \mathrm{mL}$ (Table 4$3)$. The average concentration of plutonium239,240 for all offsite locations (Table 4-3) was . not above environmental levels. Onsite concen- trations of plutonium-239,240 in air ranged from below the environmental level to $0.89 \mathrm{x}$ $10^{-18} \mu \mathrm{Ci} / \mathrm{mL}$ (Table 4-3). The average onsite concentration of plutonium-239,240 was $0.002 \mathrm{x}$ $10^{-18} \mu \mathrm{Ci} / \mathrm{mL}$. This average is $0.00001 \%$ of the DOE DCG.

Table 4-1. Incremental Concentrations ${ }^{2}$ of Plutonium-238 in Air at Sampling Locations in 1991

\begin{tabular}{|c|c|c|c|c|c|}
\hline \multirow[b]{2}{*}{ Location* } & \multirow{2}{*}{$\begin{array}{c}\text { Number } \\
\text { of } \\
\text { Samples }\end{array}$} & \multicolumn{3}{|c|}{$\begin{array}{l}\text { Plutonium-238 } \\
\left(10^{-12} \mu \mathrm{Ci} / \mathrm{mL}\right)\end{array}$} & \multirow{2}{*}{$\begin{array}{c}\text { Average as a } \\
\text { percent of } \\
\text { DOE DCG }\end{array}$} \\
\hline & & Minimum & Maximum & Average $^{b, c}$ & \\
\hline \multicolumn{6}{|l|}{ Offsite } \\
\hline 101 & 4 & 0.2 & 0.73 & $0.42 \pm 0.53$ & 0.001 \\
\hline 102 & 4 & 0.58 & 2.88 & $1.77 \pm 1.61$ & 0.006 \\
\hline 103 & 4 & 1.05 & 3.51 & $2.5 \pm 1.72$ & 0.008 \\
\hline 104 & 4. & 0.31 & 6.33 & $2.59 \pm 4.39$ & 0.009 \\
\hline 105 & 4. & 0.04 & 2.63 & $0.88 \pm 1.93$ & 0.003 \\
\hline 108 & 4 & -0.18 & 0.05 & $-0.11 \pm 0.42$ & e \\
\hline 110 & 4 & -0.45 & 0.1 & $-0.19 \pm 0.53$ & e \\
\hline 111 & 4 & -0.25 & 0.48 & $0.12 \pm 0.63$ & 0.0004 \\
\hline 112 & 4 & -0.18 & 0.72 & $0.06 \pm 0.81$ & 0.0002 \\
\hline 115 & 4 & -0.16 & 0.32 & $-0.01 \pm 0.52$ & e \\
\hline 118 & 4 & -0.07 & 5.05 & $1.5 \pm 3.87$ & 0.005 \\
\hline 122 & 12 & -0.52 & 2.77 & $1.34 \pm 0.79$ & 0.004 \\
\hline 123 & 12 & -0.01 & 6.1 & $2.63 \pm 1.11$ & 0.009 \\
\hline 124 & 12 & 0.01 & 50.58 & $10.01 \pm 9.18$ & 0.03 \\
\hline \multicolumn{6}{|l|}{ Onsite } \\
\hline 211 & 12 & 4.9 & 49.72 & $15.73 \pm 7.81$ & 0.05 \\
\hline 212 & 11 & 1.29 & 9.16 & $4.92 \pm 1.75$ & 0.02 \\
\hline 213 & 12 & 12.14 & 69.36 & $34.23 \pm 10.9$ & 0.11 \\
\hline 214 & 12 & 2.27 & 24.65 & $7.7 \pm 3.75$ & 0.03 \\
\hline 215 & 12 & 1.2 & 27.73 & $6.82 \pm 4.78$ & 0.02 \\
\hline
\end{tabular}

a Average environmental level (e.l.) shown in Table 3-2 subtracted from the data.

b Error limits are estimates of the standard error of the estimated means at the $95 \%$ confidence level.

c LDL for monthly values of plutonium-238 in air is $0.7 \times 10^{-18} \mu \mathrm{Ci} / \mathrm{mL}$; for quarterly values, $0.2 \times 10^{-18} \mu \mathrm{Ci} / \mathrm{mL}$.

d DOE DCG for plutonium-238 in air is $30,000 \times 10^{-18} \mu \mathrm{Ci} / \mathrm{mL}$.

e Below environmental level.

* Offsite sampling locations shown on Figure 4-2, p. 4-3. Onsite sampling locations shown on Figure 4-1, p. 4-2. 
Table 4-2. Incremental Concentrations a of Tritium Oxide in Air at Sampling Locations in 1991

\begin{tabular}{|c|c|c|c|c|c|c|c|}
\hline \multirow{2}{*}{\multicolumn{2}{|c|}{ Location* }} & \multirow{2}{*}{$\begin{array}{l}\text { Number } \\
\text { of } \\
\text { Samples }\end{array}$} & \multicolumn{3}{|c|}{$\begin{array}{l}\text { Tritium Oxide } \\
\left(10^{-12} \mu \mathrm{Ci} / \mathrm{mL}\right)\end{array}$} & \multirow{2}{*}{\multicolumn{2}{|c|}{$\begin{array}{l}\text { Average as a } \\
\text { Percent of } \\
\text { DOE DCG }\end{array}$}} \\
\hline & & & Minimum & Maximum & Average $^{b, c}$ & & \\
\hline \multicolumn{8}{|l|}{ Offsite } \\
\hline 101 & & 50 & -5.46 & 31.14 & $6.85 \pm 2.47$ & 0.007 & \\
\hline 102 & & 52 & -11.16 & 27.79 & $8.27 \pm 2.44$ & 0.008 & \\
\hline .103 & & 52 & -13.2 & 20.2 & $5.83 \pm 2.29$ & 0.006 & \\
\hline 104 & & 52 & -9.66 & 22.43 & $3.45 \pm 1.98$ & 0.003 & \\
\hline 105 & & 52 & -10.3 & 32.85 & $4.52 \pm 2.46$ & 0.005 & \\
\hline 108 & & 52 & -10.61 & 12.79 & $1.74 \pm 1.84$ & 0.002 & \\
\hline 110 & & 52 & -13.2 & 20.88 & $0.7 \pm 2.04$ & 0.0007 & \\
\hline 111 & & 50 & -11.34 & 11.42 & $0.44 \pm 1.79$ & 0.0004 & \\
\hline 112 & & 51 & -6.64 & 13.43 & $2.02 \pm 1.67$ & 0.002 & \\
\hline 115 & $\cdot$ & 52 & -12.7 & 12.93 & $0.58 \pm 1.83$ & 0.0006 & \\
\hline 118 & & 52 & -10.25 & 24.59 & $2.76 \pm 1.81$ & 0.003 & \\
\hline 122 & & 51 & -4.1 & 25.63 & $7.39 \pm 2.45$ & 0.007 & \\
\hline 123 & & 52 & -4.21 & 74.37 & $9.06 \pm 3.76$ & 0.009 & \\
\hline 124 & & 51 & -12.85 & 40.5 & $6.93 \pm 2.61$ & 0.007 & \\
\hline Onsite & & & & . & & & $\cdot$ \\
\hline 211 & & 51 & -0.35 & 42.41 & $11.65 \pm 3.35$ & 0.01 & \\
\hline 212 & & 49 & -4.93 & 54.88 & $13.05 \pm 3.18$ & 0.01 & \\
\hline 213 & $\cdot$ & 50 & 10.04 & 112.61 & $38.91 \pm 6.53$ & 0.04 & \\
\hline 214 & & 51 & -3.06 & 28.69 & $9.97 \pm 2.66$ & 0.01 & \\
\hline 215 & & 51 & -9.88 & 31.45 & $6.18 \pm 2.66$ & 0.006 & \\
\hline
\end{tabular}

2 Average environmental level (e.l.) found in Table 3-2 subtracted from the data.

b Error limits are estimates of the standard error of the estimated means at the $95 \%$ confidence level.

c LDL for tritium oxide in air is $16 \times 10^{-12} \mu \mathrm{Ci} / \mathrm{mL}$.

d DOEDCG for tritium oxide in air is $100,000 \times 10^{-12} \mu \mathrm{Ci} / \mathrm{mL}$. This value has been adjusted to include the fraction of tritium oxide which is absorbed through the skin as part of the inhalation pathway.

* Offsite sampling locations shown on Figure 42, p. 4-3.

Onsite sampling locations shown on Figure 4-1, p. 4-2. 
Table 4-3. Incremental Concentrations * of Plutonium-239,240

in Air at Sampling Locations in 1991



a Average environmental level (e.1.) found in Table 3-2 subtracted from the data.

b Error limits are estimates of the standard error of the estimated means at the $95 \%$ confidence level.

c LDL for monthly values of plutonium-239,240 in air is $0.3 \times 10^{-18} \mu \mathrm{Ci} / \mathrm{mL}$. LDL for quarterly values of plutonium239,240 in air is $0.1 \times 10^{-18} \mu \mathrm{Ci} / \mathrm{mL}$.

d DOE DCG for plutonium-239,240 is $20,000 \times 10^{-18} \mu \mathrm{Ci} / \mathrm{mL}$.

- Below environmental level.

* Offsite sampling locations shown on Figure 42, p. 4-3.

Onsite sampling locations shown on Figure 4-1, p. 4-2. 


\subsection{SURFACE WATER/SEDIMENT/ GROUNDWATERMONITORINGSYSTEM}

\subsubsection{Description of Monitoring Program}

\subsubsection{Effluent Monitoring}

Flow-proportional samples were collected from radiological and NPDES effluent sampling locations 5002, 5601, and 5602 (Figure 43). Samples were collected four times during the four-day workweek: three 24-hour samples collected on Tuesdays, Wednesdays and Thursdays; and one 96-hour sample collected on Mondays. Samples were analyzed four times a week for tritium and were composited weekly and analyzed for plutonium-238, plutonium-239,240, and uranium233,234 .

\subsubsection{Environmental Surveillance}

Water sampling locations along the banks of the Great Miami River were selected according to guidelines recommended by EPA (1972). The locations, shown in Figure 4-4, provide samples that are representative of river water after considerable mixing of the effluent from Mound has occurred. Water samples were collected at these locations and analyzed weekly for tritium and monthly for plutonium-238, uranium-233,234, and uranium-238.

Seven additional surface water locations, such as ponds, in all quadrants surrounding Mound, as shown in Figure 4-4, were sampled quarterly for plutonium and tritium analyses.

Drinking water from communities in the surrounding area was sampled and analyzed monthly for tritium. These communities and their relative locations are shown in Figure 1-2. Drinking water from privately-owned wells was also analyzed for tritium. A privately-owned well and Miamisburg city water were sampled and analyzed for plutonium-238, uranium-233,234 and uranium-238.

Weekly samples from onsite wells were analyzed for tritium. Monthly samples from these same wells were analyzed for plutonium-238, uranium-233,234 and uranium-238.
Silt samples were collected from the river and pond locations shown in Figure 4-4 and analyzed quarterly for plutonium-238. Scoop samples were collected to an approximate depth of $2 \mathrm{~cm}$ and then dried in an oven prior to analysis.

\subsubsection{Applicable Standards}

DOE Order 5400.5 establishes radiation dose limits for the general public as well as DCGs for discharges of radioactively contaminated liquids to surface waters. The DCG for ingested water is the concentration of a radionuclide in water that, under conditions of continuous exposure for one year, would result in an effective dose equivalent of $100 \mathrm{mrem}(1.0 \mathrm{mSv})$.

The radiation exposure limits defined in DOE Order 5400.5 are an EDE of 100 mrem/year (1.0 $\mathrm{mSv} / \mathrm{year}$ ) fromall exposure pathways. The Order specifies that DOE drinking water systems should comply with the requirements of $40 \mathrm{CFR} 141$ and shall not cause persons consuming the water to receive an effective dose equivalent greater than 4 mrem $(0.04 \mathrm{mSv})$. The Order further specifies that the dose limit is an annual limit of $4 \%$ of the appropriate DCG value averaged on the basis of monthly measurements.

EPA has promulgated maximum contaminant levels (MCLs) for radionuclides in community water systems which appear in two forms: concentration limits for certain alpha-emitting radionuclides (40 CFR 141.15) and an annual dose limit for the ingestion of certain beta-and gammaemitting radionuclides ( $40 \mathrm{CFR}$ 141.16). EPA specifies $20,000 \mathrm{pCi} / \mathrm{L}$ for tritium. For the other radionuclides included in this report, the annual dose equivalent shall not exceed 4 mrem $(0.04$ $\mathrm{mSv}$ ). This is equivalent to a concentration that is $4 \%$ of the DOE DCG. If two or more radionuclides are present, the sum of their annual dose equivalent to the total body or to any organ shall not exceed $4 \mathrm{mrem}(0.04 \mathrm{mSv}) /$ year.

There are no applicable standards for radionuclide concentrations in silt or sediment. 

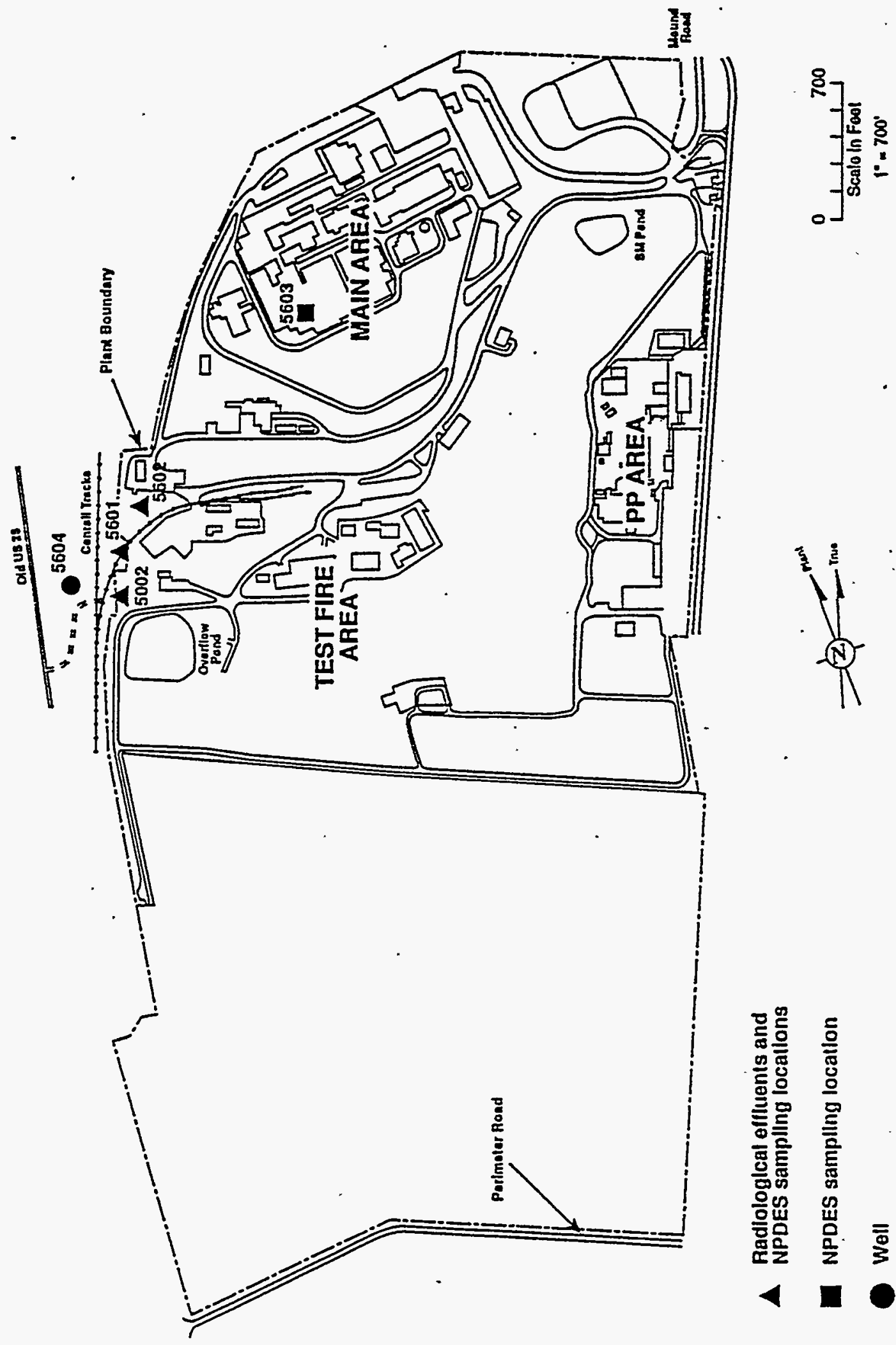



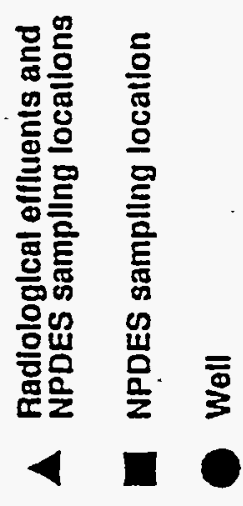




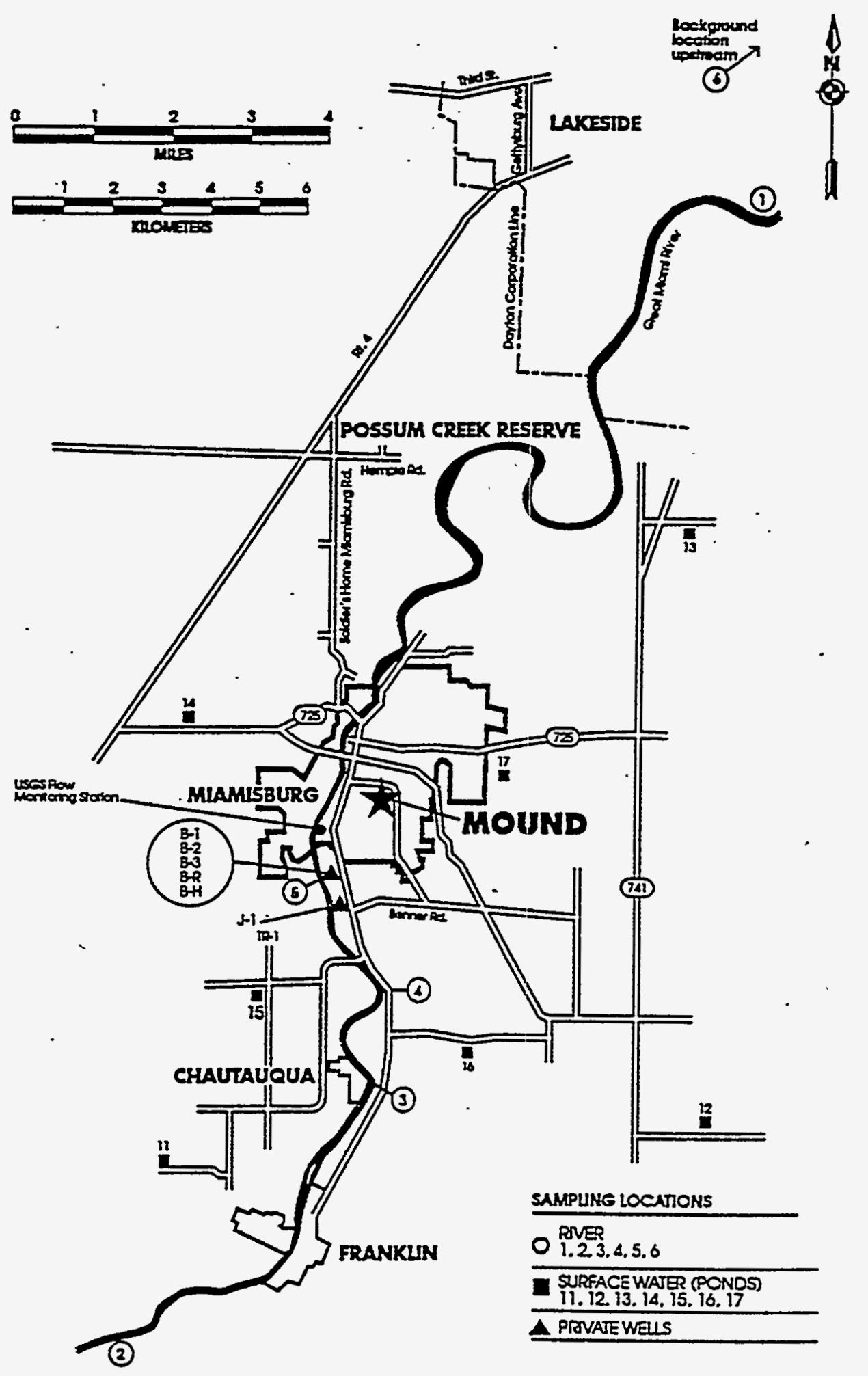

Figure 4-4. Sampling locations for river water, surface water, and private wells 


\subsubsection{Results}

The total discharges to the Great Miami River during 1991 consisted of $3.2 \mathrm{Ci}$ of tritium, $4.5 \mathrm{x}$ $10^{-4} \mathrm{Ci}$ of plutonium-238,3.4 $\times 10^{-4} \mathrm{Ci}$ of uranium233,234 , and $9.7 \times 10^{-6} \mathrm{Ci}$ of plutonium-239,240 (Table E-1). The 1991 discharges can be compared to the 5-year trend data presented in Figures E-2 to E-9. Tritium ranged from $5.7 \mathrm{Ci}$ in 1989 to the 1991 low of $3.2 \mathrm{Ci}$. The 5-year range for plutonium-238 was $1.4 \times 10^{-3} \mathrm{Ci}$ in 1989 to the 1991 low of $4.5 \times 10^{-4} \mathrm{Ci}$. Uranium-233,234 ranged from $4.5 \times 10^{-4} \mathrm{Ci}$ in 1990 to $3.2 \times 10^{-4} \mathrm{Ci}$ in 1987. Plutonium-239,240 ranged from $2.7 \mathrm{x}$ $10^{-5}$ to $4.1 \times 10^{-6} \mathrm{Ci}$. None of the 1991 values represented an increase in the 5-year trend, and two; tritium and plutonium-238, represented 5year lows.

The average incremental concentration of tritium measured at all locations in the Great Miami River was $0.02 \times 10^{-6} \mu \mathrm{Ci} / \mathrm{mL}, 0.001 \%$ of $\mathrm{DOE}$ DCG. Concentrations at each location are summarized in Table 4-4.

Table 4-4. Incremental Concentrations ${ }^{2}$ of Tritium in the Great Miami River in 1991

\begin{tabular}{|c|c|c|c|c|c|}
\hline \multirow{2}{*}{ Location* } & \multirow{2}{*}{$\begin{array}{l}\text { Number } \\
\text { of } \\
\text { Samples }\end{array}$} & \multicolumn{3}{|c|}{$\begin{array}{c}\text { Tritium } \\
\left(10^{-6} \mu \mathrm{Ci} / \mathrm{mL}\right)\end{array}$} & \multirow{2}{*}{$\begin{array}{l}\text { Average as a } \\
\text { Percent of } \\
\text { DOE DCG }^{d}\end{array}$} \\
\hline & & Minimum & Maximum & Average $^{b, c}$ & \\
\hline & & \multicolumn{2}{|l|}{ : } & & \\
\hline 1 & 51 & -0.38 & 0.27 & $0.02 \pm 0.1$ & 0.001 \\
\hline 2 & 51 & -0.35 & 0.41 & $-0.003 \pm 0.1$ & c \\
\hline 3 & 51 & -0.28 & 0.21 & $0.01 \pm 0.1$ & 0.0005 \\
\hline 4 & 51 & -0.46 & 0.34 & $0.04 \pm 0.1$ & 0.002 \\
\hline \multirow[t]{2}{*}{5} & 51 & -0.27 & 0.29 & $0.02 \pm 0.1$ & 0.001 \\
\hline & & & . & & \\
\hline
\end{tabular}

A Average environmental level (e.l.) found in Table 3-2 subtracted from the data.

b Error limits are estimates of the standard error of the estimated means at the $95 \%$ confidence level.

c $\mathrm{LDL}$ for tritium in water is $0.5 \times 10^{-6} \mu \mathrm{Ci} / \mathrm{mL}$.

d DOE DCG for tritium in water is $2,000 \times 10^{-6} \mu \mathrm{Ci} / \mathrm{mL}$.

c Below environmental levels.

* Sampling locations shown on Figure 4-4, p. 4-10. 
$\therefore$

Water samples collected and analyzed for plulocations in the Great Miami River was $0.07 \mathrm{x}$ tonium-238 on a monthly basis showed the average incremental concentration measured for all $10^{-12} \mu \mathrm{Ci} / \mathrm{mL}$, which is $0.0002 \%$ of the DOE DCG. Concentrations at each location are summarized in Table 4-5.

Table 4-5. Incremental Concentrations of Plutonium-238 in the Great Miami River in 1991

\begin{tabular}{|c|c|c|c|c|c|}
\hline \multirow[b]{2}{*}{ Location* } & \multirow{2}{*}{$\begin{array}{l}\text { Number } \\
\text { of } \\
\text { Samples }\end{array}$} & \multicolumn{3}{|c|}{$\begin{array}{l}\text { Plutonium-238 } \\
\left(10^{-12} \mu \mathrm{Ci} / \mathrm{mL}\right)\end{array}$} & \multirow{2}{*}{$\begin{array}{l}\text { Average as a } \\
\text { Percent of } \\
\text { DOEDCG }\end{array}$} \\
\hline & & $\overline{\text { Minimum }}$ & Maximum & Average ${ }^{b, c}$ & \\
\hline 1 & 12 & -12.76 & 4.72 & $0.22 \pm 3.86$ & 0.0006 \\
\hline 2 & 12 & -10.74 & 3.97 & $-0.71 \pm 3.67$ & $=$ \\
\hline 3 & 12 & -11.79 & 6.39 & $-0.51 \pm 3.69$ & e \\
\hline 4 & 12 & -6.99 & 5.91 & $0.81 \pm 3.56$ & 0.002 \\
\hline 5 & 12 & -11.0 & 10.66 & $0.52 \pm 4.46$ & 0.001 \\
\hline
\end{tabular}

s Average environmental level (e.1.) found in Table 3-2 subtracted from the data.

b Error limits are estimates of the standard error of the estimated means at the $95 \%$ confidence level.

c LDL for plutonium-238 in river water is $21.3 \times 10^{-12} \mu \mathrm{Ci} / \mathrm{mL}$.

d DOE DCG for plutonium-238 in water is $40,000 \times 10^{-12} \mu \mathrm{Ci} / \mathrm{mL}$.

- Below environmental level.

* Sampling locations shown on Figure 4-4, p. 4-10. 
River water was sampled for uranium-233,234, and uranium-238 during 1991, and results are shown in Table 4-6. The average incremental concentration for uranium-233,234 was $0.01 \mathrm{x}$ $10^{-9} \mu \mathrm{Ci} / \mathrm{mL}, 0.002 \%$ of the DOE DCG; uranium238 did not exceed environmental levels.

Table 4-6. Incremental Concentrations a of Uranium-233, 234 and Uranium-238 in the Great Miami River in 1991

\begin{tabular}{|c|c|c|c|c|c|}
\hline \multirow[b]{2}{*}{ Location* } & \multirow{2}{*}{$\begin{array}{c}\text { Number } \\
\text { of } \\
\text { Samples }\end{array}$} & \multicolumn{3}{|c|}{$\begin{array}{c}\text { Uranium-233,234 } \\
\left(10^{-9} \mu \mathrm{Ci} / \mathrm{mL}\right)\end{array}$} & \multirow{2}{*}{$\begin{array}{c}\text { Average as a } \\
\text { Percent of } \\
\text { DOE DCG }^{d}\end{array}$} \\
\hline & & Minimum & Maximum & Average ${ }^{b, c}$ & \\
\hline 1 & 12 & -0.05 & 0.24 & $0.1 \pm 0.11$ & 0.02 \\
\hline 2 & 12 & -0.18 & 0.12 & $-0.03 \pm 0.11$ & e \\
\hline 3 & 12 & -0.17 & 0.12 & $0.003 \pm 0.11$ & 0.0006 \\
\hline 4 & 12 & -0.16 & 0.18 & $0.01 \pm 0.11$ & 0.002 \\
\hline \multirow[t]{2}{*}{5} & 12 & -0.18 & 0.13 & $-0.01 \pm 0.11$ & e \\
\hline & $\begin{array}{l}\text { Number } \\
\text { of }\end{array}$ & \multicolumn{3}{|c|}{$\begin{array}{l}\text { Uranium-238 } \\
\left(10^{-9} \mu \mathrm{Ci} / \mathrm{mL}\right)\end{array}$} & $\begin{array}{c}\text { Average as a } \\
\text { Percent of }\end{array}$ \\
\hline Location ${ }^{*}$ & Samples & Minimum & Maximum & Average ${ }^{b, c}$ & DOE DCG $^{d}$ \\
\hline 1 & 12 & -0.07 & 0.2 & $0.07 \pm 0.10$ & 0.01 \\
\hline 2 & 12 & -0.15 & 0.09 & $-0.04 \pm 0.09$ & e \\
\hline 3 & 12 & -0.16 & 0.18 & $-0.02 \pm 0.10$ & e \\
\hline 4 & 12 & -0.24 & 0.12 & $-0.04 \pm 0.12$ & e \\
\hline 5 & 12 & -0.24 & 0.15 & $-0.03 \pm 0.11$ & e \\
\hline
\end{tabular}

a Average environmental level (e.l.) found in Table 3-2 subtracted from the data.

b Error limits are estimates of the standard error of the estimated means at the $95 \%$ confidence level.

c LDL for uranium-233,234 is $0.04 \times 10^{-9} \mu \mathrm{Ci} / \mathrm{mL}$. The $\mathrm{LDL}$ for uranium-238 is $0.03 \times 10^{-9} \mu \mathrm{Ci} / \mathrm{mL}$.

d DOE DCG for uranium-233,234 in water is $500 \times 10^{-9} \mu \mathrm{Ci} / \mathrm{mL}$. The DOE DCG for uranium-238 is $600 \times 10^{-9} \mu \mathrm{Ci} /$ $\mathrm{mL}$.

e Below environmental level.

* Sampling locations shown on Figure 44, p. 4-10.

Concentrations of tritium and plutonium-238 in ponds offsite are shown in Tables 4-7 and 4-8, respectively. The average concentrations of tritium for all locations was $0.09 \times 10^{-6} \mu \mathrm{Ci} / \mathrm{mL}$, representing $0.005 \%$ of the DOE DCG. The average concentration of plutonium- 238 was 0.37 $\times 10^{-12} \mu \mathrm{Ci} / \mathrm{mL}, 0.0009 \%$ of the DOE DCG. 
:-

Table 4-7. Incremental Concentrations ${ }^{2}$ of Tritium

in Surface Water in 1991

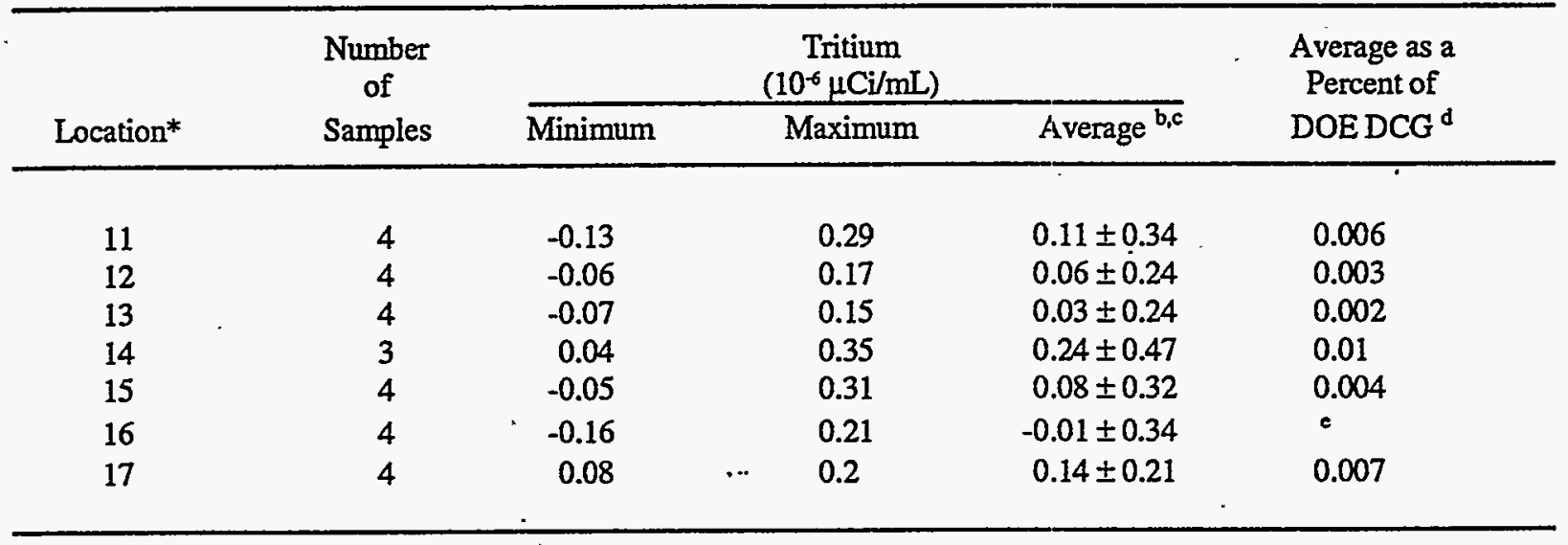

a Average environmental level (e.l.) found in Table 3-2 subtracted from the data.'

b Error limits are estimates of the standard error of the estimated means at the $95 \%$ confidence level.

c LDL for tritium in surface water is $0.4 \times 10^{-6} \mu \mathrm{Ci} / \mathrm{mL}$.

d DOE DCG for tritium in water is $2,000 \times 10^{-6} \mu \mathrm{Ci} / \mathrm{mL}$.

- Below environmental level.

* Sampling locations shown on Figure 4-4, p. 4-10.

Table 4-8. Incremental Concentrations ${ }^{\mathrm{a}}$ of Plutonium-238

in Surface Water in 1991

\begin{tabular}{|c|c|c|c|c|c|}
\hline & $\begin{array}{l}\text { Number } \\
\text { of }\end{array}$ & & $\begin{array}{l}\text { Plutonium-238 } \\
\left(10^{-12} \mu \mathrm{Ci} / \mathrm{mL}\right)\end{array}$ & & $\begin{array}{l}\text { Average as a } \\
\text { Percent of }\end{array}$ \\
\hline Location* & Samples & Minimum & Maximum & Average ${ }^{b, c}$ & DOE DCG ${ }^{d}$ \\
\hline 11 & 4 & -5.43 & 6.78 & $0.49 \pm 8.34$ & 0.001 \\
\hline 12 & 4 & -2.68 & 0.78 & $-0.77 \pm 3.44$ & e \\
\hline 13 & 4 & -0.7 & 3.88 & $1.11 \pm 3.98$ & 0.003 \\
\hline 14 & 3 & -2.38 & 2.73 & $0.17 \pm 5.25$ & 0.0004 \\
\hline 15 & 4 & -0.66 & 2.58 & $0.35 \pm 3.38$ & 0.0009 \\
\hline 16 & 4 & -2.4 & 2.25 & $0.03 \pm 4.33$ & 0.0001 \\
\hline 17 & 4 & 0.67 & 1.73 & $1.23 \pm 2.51$ & 0.003 \\
\hline
\end{tabular}

a Average environmental level (e.l.) found in Table 3-2 subtracted from the data.

b Error limits are estimates of the standard error of the estimated means at the $95 \%$ confidence level.

c LDL for plutonium-238 in surface water is $12.0 \times 10^{-12} \mu \mathrm{Ci} / \mathrm{mL}$.

d DOE DCG for plutonium-238 in water is $40,000 \times 10^{-12} \mu \mathrm{Ci} / \mathrm{mL}$.

- Below environmental level.

* Sampling locations shown on Figure 4-4, p.4-10. 
Tritium concentrations in community drinking water samples are summarized in Table 4-9. The average concentration of tritium in community drinking water was below the value of the reagent blank (Table 4-9). The environmental level for tritium in water shown in Table 3-2 is not subtracted from these data because the EPA standard assesses total concentration including background.

Table 4-9. Tritium Concentrations ${ }^{2}$ in Community Drinking Water in 1991

\begin{tabular}{|c|c|c|c|c|c|c|}
\hline \multirow[b]{2}{*}{ Location* } & \multirow{2}{*}{$\begin{array}{l}\text { Number } \\
\text { of } \\
\text { Samples }\end{array}$} & \multicolumn{3}{|c|}{$\begin{array}{c}\text { Tritium } \\
\left(10^{-6} \mu \mathrm{Ci} / \mathrm{mL}\right)\end{array}$} & \multirow[t]{2}{*}{$\begin{array}{c}\text { Average as a } \\
\text { Percent } \\
\text { of EPA } \\
\text { Standard }\end{array}$} & \\
\hline & & Minimum & Maximum & Average ${ }^{b, c}$ & & \\
\hline & & & & & & \\
\hline & 12 & -0.50 & -0.04 & $-0.10 \pm 0.00$ & 4 & \\
\hline Centerville & 12 & -0.32 & 0.04 & $-0.17 \pm 0.06$ & d & \\
\hline Dayton & 12 & -0.29 & -0.02 & $-0.16 \pm 0.06$ & d & \\
\hline Franklin & 12 & -0.19 & 0.03 & $-0.08 \pm 0.04$ & d & \\
\hline Germantown & 12 & -0.33 & -0.06 & $-0.18 \pm 0.05$ & d & \\
\hline Kettering & 12 & -0.43 & 0.05 & $-0.16 \pm 0.08$ & d & \\
\hline Miamisburg & 12 & 0.13 & 0.67 & $0.43 \pm 0.11$ & 2.2 & \\
\hline Middletown & 12 & -0.32 & -0.01 & $-0.15 \pm 0.06$ & d & \\
\hline Moraine & 12 & -0.37 & -0.03 & $-0.16 \pm 0.06$ & d & \\
\hline Springboro & 12 & -0.23 & 0.14 & $-0.05 \pm 0.06$ & d & \\
\hline Waynesville & 12 & -0.28 & -0.05 & $-0.18 \pm 0.04$ & d & \\
\hline West Carrollton & 12 & -0.22 & -0.02 & $-0.13 \pm 0.03$ & d & \\
\hline
\end{tabular}

a Average environmental level (e.l.) not subtracted from the data. The EPA standard of $20 \times 10^{-6} \mu \mathrm{Ci} / \mathrm{mL}$ assesses total concentration including background.

brror limits are estimates of the standard error of the estimated means at the $95 \%$ confidence level.

c LDL for tritium in community drinking water is $0.4 \times 10^{-6} \mu \mathrm{Ci} / \mathrm{mL}$.

d Below reagent blanks.

* Sampling locations shown on Figure 4-4, p. 4-10. 
The average concentration of tritium for all privately-owned wells was $1.88 \times 10^{-6} \mu \mathrm{Ci} / \mathrm{mL}$, which is $9.4 \%$ of the EPA Standard. These data are shown in Table 4-10. Tritium concentrations in onsite drinking water wells (Figure 4-5) ranged from $0.4 \times 10^{-6} \mu \mathrm{Ci} / \mathrm{mL}$ to $4.6 \times 10^{-6} \mu \mathrm{Ci} / \mathrm{mL}$ (Table 4-11). The average concentration of tritium in Mound's onsite wells was $2.5 \times 10^{-6} \mu \mathrm{Ci} /$ $\mathrm{mL}$, which is $12.5 \%$ of the EPA Standard.

Table 4-10. Tritium Concentrations ${ }^{2}$ in Privately-owned Wells in 1991

\begin{tabular}{|c|c|c|c|c|c|}
\hline \multirow[b]{2}{*}{ Location* } & \multirow{2}{*}{$\begin{array}{c}\text { Number } \\
\text { of } \\
\text { Samples }\end{array}$} & \multicolumn{3}{|c|}{$\begin{array}{c}\text { Tritium } \\
\left(10^{-6} \mu \mathrm{Ci} / \mathrm{mL}\right)\end{array}$} & \multirow{2}{*}{$\begin{array}{l}\text { Average as a } \\
\text { Percent } \\
\text { of EPA } \\
\text { Standard }\end{array}$} \\
\hline & & $\overline{\text { Minimum }}$ & Maximum & Average ${ }^{b, c}$ & \\
\hline $\mathrm{J}-1^{\mathrm{e}}$ & 12 & 0.87 & 1.65 & $1.35 \pm 0.14$ & 6.8 \\
\hline B-H & 7 & 1.95 & 2.59 & $2.25 \pm 0.18$ & 11.3 \\
\hline B-R & 6 & 2.71 & 4.47 & $3.59 \pm 0.65$ & 18.0 \\
\hline $\operatorname{Tr}-1^{e}$ & 12 & 0.1 & 0.44 & $0.31 \pm 0.07$ & 1.6 \\
\hline \multicolumn{6}{|c|}{$\begin{array}{l}\text { Average environmental level (e.l.) not subtracted from the data. The EPA standard of } 20 \times 10^{-6} \mu \mathrm{Ci} / \mathrm{mL} \text { assesses total } \\
\text { concentration including background. }\end{array}$} \\
\hline \multicolumn{6}{|c|}{ Locations B-1 through B-3 are no longer used as drinking water sources; therefore sampling has been suspended. } \\
\hline \multicolumn{6}{|c|}{ c Error limits are estimates of the standard error of the estimated means at the $95 \%$ confidence level. } \\
\hline \multicolumn{6}{|c|}{ d $L D L$ for tritium in privately-owned well water is $0.6 \times 10^{-6} \mu \mathrm{Ci} / \mathrm{mL}$. } \\
\hline \multicolumn{6}{|c|}{ c Private drinking water supply well. } \\
\hline * Samplin & hownc & 31 & & & \\
\hline
\end{tabular}

Table 4-11. Tritium Concentrations ${ }^{*}$ in Onsite Wells in 1991

\begin{tabular}{lccccc}
\hline & $\begin{array}{c}\text { Number } \\
\text { of } \\
\text { Location* }\end{array}$ & Samples & Minimum & $\begin{array}{c}\text { Tritium } \\
\left(10^{-6} \mu \mathrm{Ci} / \mathrm{mL}\right)\end{array}$ & $\begin{array}{c}\text { Average as a } \\
\text { Percent } \\
\text { of EPA } \\
\text { Standard }\end{array}$ \\
\hline & & & & & \\
Well No. 1 & 51 & 2.1 & 4.6 & $3.5 \pm 0.2$ & 17.5 \\
Well No. 2 & 50 & 1.5 & 3.7 & $2.5 \pm 0.2$ & 12.5 \\
Well No. 3 & 34 & 0.4 & 3.4 & $1.5 \pm 0.2$ & 7.5 \\
\hline
\end{tabular}

${ }^{2}$ Average environmental level (e.l.) not subtracted from the data. The EPA standard of $20 \times 10^{-6} \mu \mathrm{Ci} / \mathrm{mL}$ assesses total concentration including background.

brror limits are estimates of the standard error of the estimated means at the $95 \%$ confidence level.

c LDL for tritium in onsite well water is $0.5 \times 10^{-6} \mu \mathrm{Ci} / \mathrm{mL}$.

* Sampling locations shown on Figure 4-5, p. 4-17. 


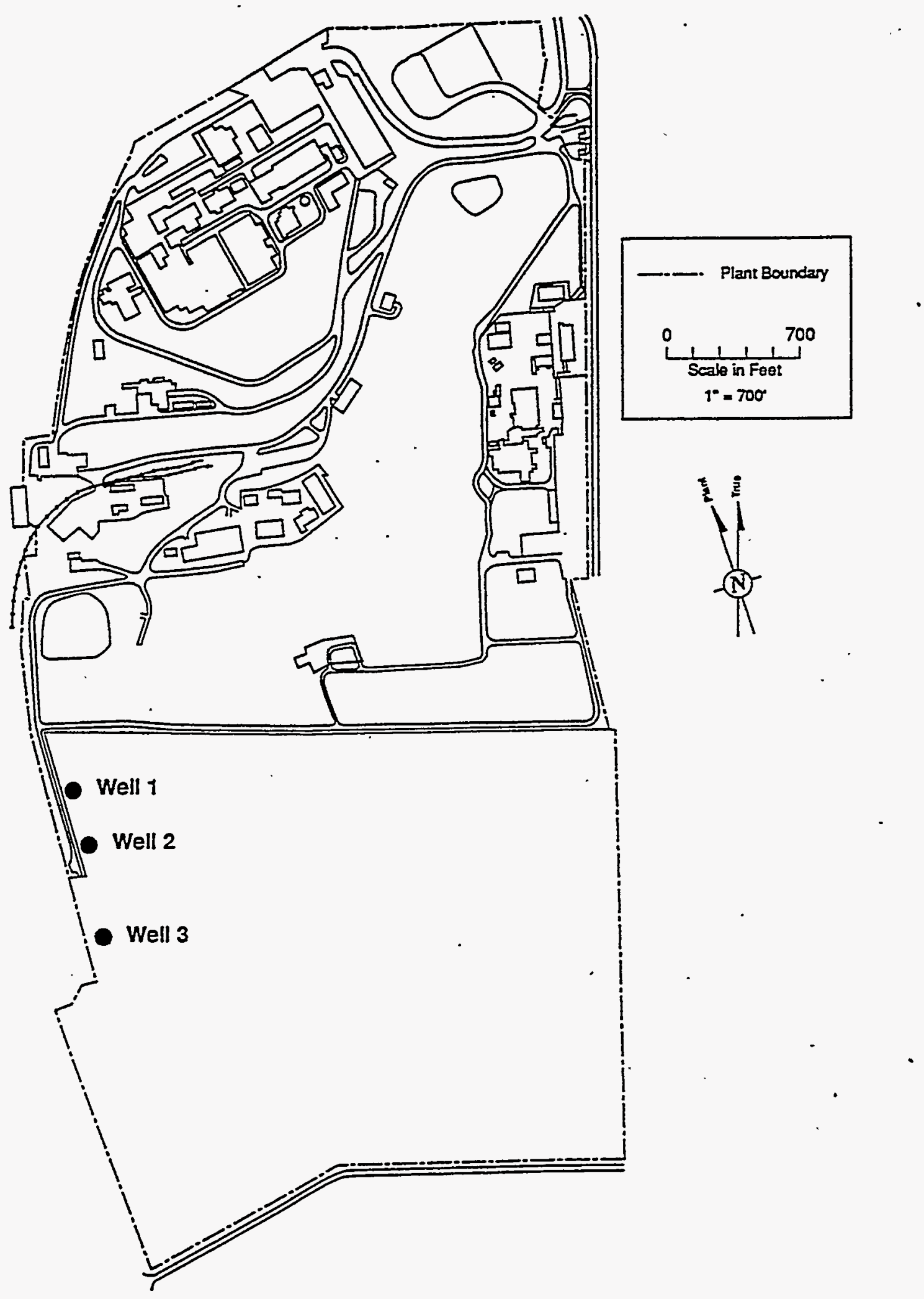

Figure 4-5. Location of onsite production wells 
Concentrations of plutonium-238 in privatelyowned wells are shown in Table 4-12. The average plutonium-238 concentration for these locations was $0.31 \times 10^{-12} \mu \mathrm{Ci} / \mathrm{mL}, 0.02 \%$ of the DOE
DCG. Concentrations in onsite well water (Table 4-13) averaged $1.15 \times 10^{-12} \mu \mathrm{Ci} / \mathrm{mL}, 0.07 \%$ of the standard for that radionuclide in drinking water of $4 \%$ of the DOE: DCG.

\section{Table 4-12. Plutonium-238 Concentrations in Privately-owned Wells and Miamisburg Municipal Drinking Water in 1991}

\begin{tabular}{|c|c|c|c|c|c|}
\hline \multirow[b]{2}{*}{ Location* } & \multirow{2}{*}{$\begin{array}{l}\text { Number } \\
\text { of } \\
\text { Samples }\end{array}$} & \multicolumn{3}{|c|}{$\begin{array}{l}\text { Plutonium-238 } \\
\left(10^{-12} \mu \mathrm{Ci} / \mathrm{mL}\right)\end{array}$} & \multirow{2}{*}{$\begin{array}{l}\text { Average as a } \\
\text { Percent of } 4 \% \\
\text { DOE DCG }^{c}\end{array}$} \\
\hline & & Minimum & Maximum & Average ${ }^{a, b}$ & \\
\hline $\begin{array}{c}\text { Miamisburg } \\
\text { J-1 }\end{array}$ & $\begin{array}{l}12 \\
12\end{array}$ & $\begin{array}{l}-4.73 \\
-4.06\end{array}$ & $\begin{array}{c}9.3 \\
11.85\end{array}$ & $\begin{array}{l}0.47 \pm 2.41 \\
0.15 \pm 2.89\end{array}$ & $\begin{array}{l}0.03 \\
0.009\end{array}$ \\
\hline $\begin{array}{l}\text { Error limit } \\
\text { b LDL for } p \\
\text { c } 4 \% \text { of DO } \\
\text { d Private dri } \\
\text { * Sampling }\end{array}$ & $\begin{array}{l}\text { imates of th } \\
\text { n-238 in dri } \\
\text { for plutonit } \\
\text { ater supply } \\
\text { s shown on }\end{array}$ & $\begin{array}{l}\text { andard error } \\
\text { Ig water is } 17 \\
38 \text { in drinkin } \\
\text { 1. } \\
\text { Ire } 4-4, \text { p. } 4\end{array}$ & $\begin{array}{l}-12 \mu \mathrm{Ci} / \mathrm{mL} \text {. } \\
\mathrm{r} \text { is } 1600 \times 10\end{array}$ & $\begin{array}{l}\text { e } 95 \% \text { confide } \\
\text { mil. }\end{array}$ & evel. \\
\hline
\end{tabular}

Table 4-13. Plutonium-238 Concentrations in Onsite Well Water in 1991

\begin{tabular}{|c|c|c|c|c|c|}
\hline & $\begin{array}{c}\text { Number } \\
\text { of }\end{array}$ & & $\begin{array}{l}\text { Plutonium-238 } \\
\left(10^{-12} \mu \mathrm{Ci} / \mathrm{mL}\right)\end{array}$ & 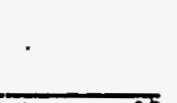 & $\begin{array}{l}\text { Average as a } \\
\text { Percent of } 4 \%\end{array}$ \\
\hline Location* & Samples & Minimum & Maximum & Average ${ }^{2,6}$ & $\mathrm{DOE}^{\mathrm{DCG}}{ }^{\mathrm{c}}$ \\
\hline Well No. 1 & 12 & -4.48 & 8.7 & $2.15 \pm 2.63$ & 0.13 \\
\hline Well No. 2 & 12 & -8.08 & 11.17 & $0.72 \pm 3.06$ & 0.05 \\
\hline Well No. 3 & 9 & -3.65 & 9.23 & $0.59 \pm 2.79$ & 0.04 \\
\hline
\end{tabular}

Error limits are estimates of the standard crror of the estimated means at the $95 \%$ confidence level.

b $\mathrm{LDL}$ for plutonium-238 in drinking water is $17.4 \times 10^{-12} \mu \mathrm{Ci} / \mathrm{mL}$.

c $4 \%$ of the DOE DCG for plutonium-238 in drinking water is $1600 \times 10^{-12} \mu \mathrm{Ci} / \mathrm{mL}$.

* Sampling locations shown on Figure 4-5, p. 4-17. 
Uranium concentrations in Miamisburg drinking water and a privately-owned well used for drinking water for 1991 are given in Table 4-14. The average concentration of uranium-233,234 was $0.32 \times 10^{-9} \mu \mathrm{Ci} / \mathrm{mL}$. This represents $1.6 \%$ of $4 \%$ of the DOE/DCG standard. The average concentration of uranium-238 was $0.28 \times 10^{-9} \mu \mathrm{Ci}$ / $\mathrm{mL}, 1.17 \%$ of $4 \%$ of the DOE DCG standard.

Table 4-14. Uranium-233, 234 and Uranium-238 Concentrations in a Privately-owned Well and Miamisburg Municipal Drinking Water in 1991

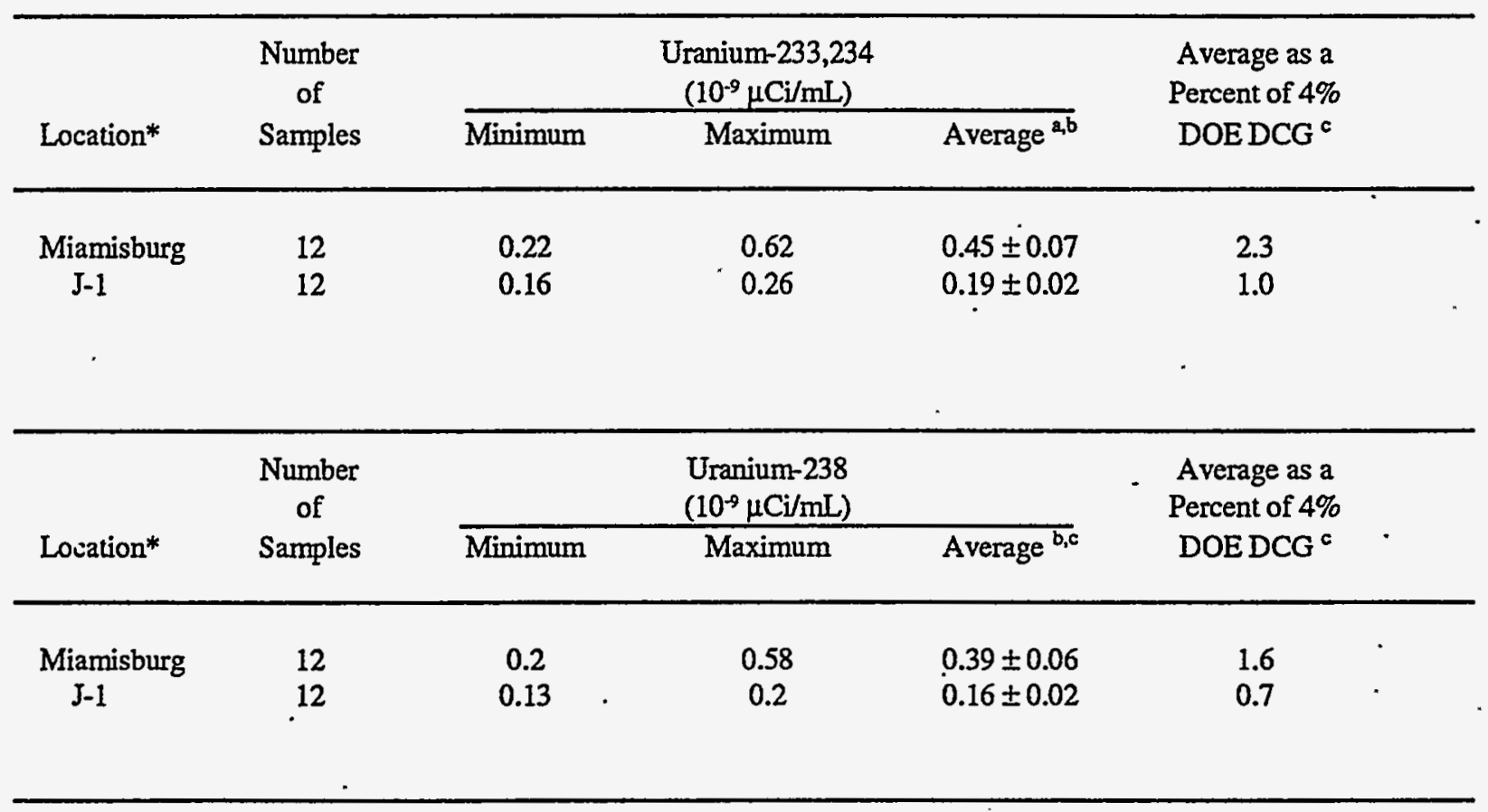

a Error limits are estimates of the standard error of the estimated means at the $95 \%$ confidence level.

b LDL for monthly uranium-233,234 is $0.03 \times 10^{-9} \mu \mathrm{Ci} / \mathrm{mL}$. The $\mathrm{LDL}$ for uranium-238 is $0.03 \times 10^{-9} \mu \mathrm{Ci} / \mathrm{mL}$.

c $4 \%$ of the DOEDCG for uranium-233,234 in drinking water is $20 \times 10^{-9} \mu \mathrm{Ci} / \mathrm{mL}$. $4 \%$ of the DOEDCG for uranium238 in drinking water is $24 \times 10^{-9} \mu \mathrm{Ci} / \mathrm{mL}$.

* Sampling locations shown on Figure 4-4, p. 4-10. 
Concentrations of uranium-233,234, and 238 in onsite wells are shown in Table 4-15. Wëll Nos. 2 and 3 are sources of onsite drinking water. Well No. 1 has been used sparingly for the past several years because it is nearest a suspected source of
VOC contamination. The average concentration of uranium-233,234 was $0.21 \times 10^{-9} \mu \mathrm{Ci} / \mathrm{mL}, 1.05 \%$ of $4 \%$ of the DOE DCG standard. The average concentration of uranium-238 was $0.18 \times 10^{-9}$ $\mu \mathrm{Ci} / \mathrm{mL}, 0.75 \%$ of $4 \%$ DOE DCG standard.

Table 4-15. Uranium-233, 234 and Uranium-238 Concentrations in Onsite Well Water in 1991

\begin{tabular}{|c|c|c|c|c|c|}
\hline \multirow[b]{2}{*}{ Location* } & \multirow{2}{*}{$\begin{array}{c}\text { Number } \\
\text { of } \\
\text { Samples }\end{array}$} & \multicolumn{3}{|c|}{$\begin{array}{c}\text { Uranium-233,234 } \\
\left(10^{-9} \mu \mathrm{Ci} / \mathrm{mL}\right)\end{array}$} & \multirow{2}{*}{$\begin{array}{c}\text { Average as a } \\
\text { Percent of } 4 \% \\
\text { DOE DCG }^{c}\end{array}$} \\
\hline & & Minimum & Maximum & Average ${ }^{a b}$ & \\
\hline Well No. 1 & 12 & 0.12 & 0.23 & $0.19 \pm 0.02$ & 1.0 \\
\hline Well No. 2 & 12 & 0.17 & 0.28 & $0.21 \pm 0.02$ & 1.1 \\
\hline \multirow[t]{2}{*}{ Well No. 3} & 8 & 0.15 & 0.26 & $0.22 \pm 0.03$ & 1.1 \\
\hline & $\begin{array}{c}\text { Number } \\
\text { of }\end{array}$ & & $\begin{array}{l}\text { Uranium-238 } \\
\left(10^{-9} \mu \mathrm{Ci} / \mathrm{mL}\right)\end{array}$ & & $\begin{array}{l}\text { Average as a } \\
\text { Percent of } 4 \%\end{array}$ \\
\hline Location* & Samples & Minimum & Maximum & Average ${ }^{a, b}$ & $\mathrm{DOE} \mathrm{DCG}^{\mathbf{c}}$ \\
\hline Well No. 1 & 12 & 0.11 & 0.21 & $0.17 \pm 0.02$ & 0.7 \\
\hline Well No. 2 & 12 & 0.15 & 0.25 & $0.19 \pm 0.02$ & 0.8 \\
\hline Well No. 3 & 8 & 0.12 & 0.21 & $0.19 \pm 0.02$ & 0.8 \\
\hline
\end{tabular}

a Enor limits are estimates of the standard error of the estimated means at the $95 \%$ confidence level.

b LDL for monthly uranium-233,234 is $0.03 \times 10^{-9} \mu \mathrm{Ci} / \mathrm{mL}$. The LDL for uranium-238 is $0.03 \times 10^{-9} \mu \mathrm{Ci} / \mathrm{mL}$.

c $4 \%$ of the DOEDCG for uranium-233,234 in drinking water is $20 \times 10^{-9} \mu \mathrm{Ci} / \mathrm{mL}$. $4 \%$ of the DOEDCG for uranium238 in drinking water is $24 \times 10^{-9} \mu \mathrm{Ci} / \mathrm{mL}$.

* Sampling locations shown on Figure 4-5, p. 4-17. 
The results of analysis of the silt samples are in Tables 4-16 and 4-17. The average concentration of plutonium-238 in river silt was $24.18 \times 10^{-9}$ $\mu \mathrm{Ci} / \mathrm{g}$. The average concentration of plutonium238 in silt at other surface water locations was
$0.93 \times 10^{-9} \mu \mathrm{Ci} / \mathrm{g}$. The overall average value, as well as the individual average values for the five locations, does not indicate a significant impact on the environment.

\section{Table 4-16. Incremental Concentrations ${ }^{2}$ of Plutonium-238 in Silt from River Sampling Locations in 1991}

\begin{tabular}{ccccc}
\hline & \multirow{2}{*}{$\begin{array}{c}\text { Number } \\
\text { of } \\
\text { Location* }\end{array}$} & $\begin{array}{c}\text { Plutonium-238 } \\
\left(10^{-9} \mu \mathrm{Ci} / \mathrm{g}\right)\end{array}$ \\
\cline { 3 - 5 } Samples & Minimum & Maximum & Average $^{\text {b.c }}$ \\
\hline 1 & 4 & -0.37 & 11.96 & $4.55 \pm 8.98$ \\
2 & 4 & 6.99 & 19.13 & $13.25 \pm 8.03$ \\
3 & 4 & 15.42 & 47.9 & $26.8 \pm 23.59$ \\
4 & 4 & 42.05 & 143.83 & $71: 65 \pm 77.47$ \\
5 & 4 & 3.25 & 5.33 & $4.63 \pm 1.9$ \\
& & & & \\
\hline
\end{tabular}

2 Average environmental level (e.1.) found in Table 3-2 subtracted from the data.

b Error limits are estimates of the standard error of the estimated means at the $95 \%$ confidence level.

c LDL for plutonium-238 in silt is $2.8 \times 10^{-9} \mu \mathrm{Ci} / \mathrm{g}$.

* Sampling locations shown on Figure 4-4, p. 4-10.

Table 4-17. Incremental Concentrations ${ }^{2}$ of Plutonium-238 in Silt from Surface Water Locations in 1991

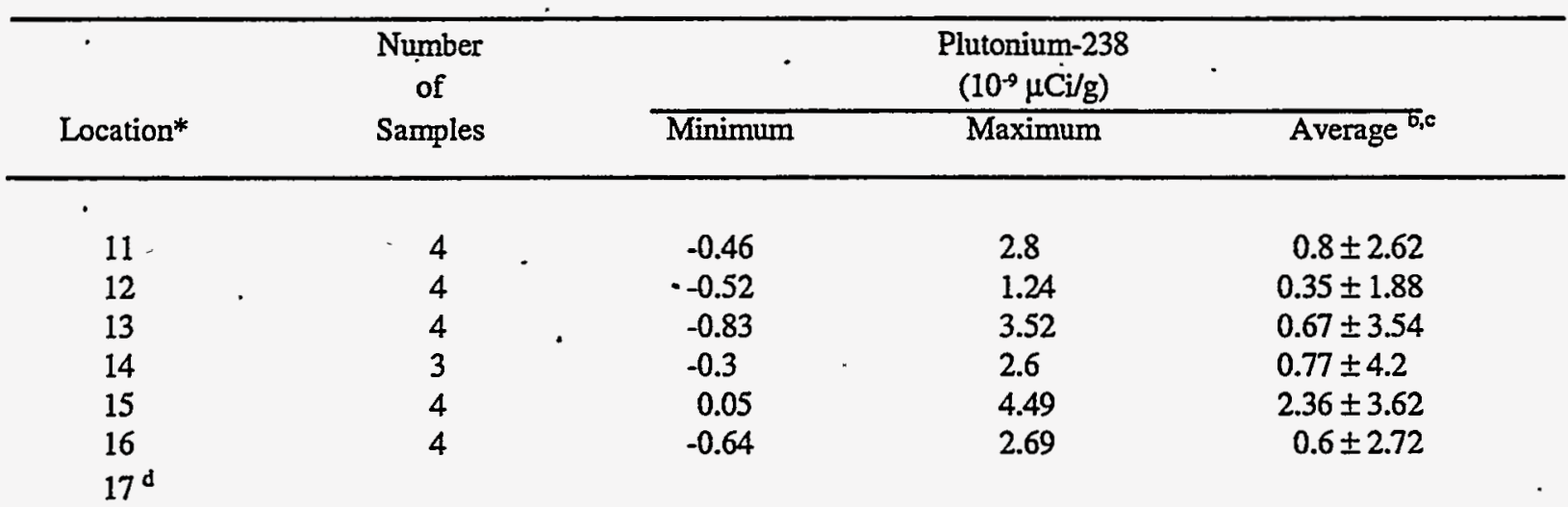

2 Average environmental level (e.1.) found in Table 3-2 subtracted from the data

b Error limits are estimates of the standard error of the estimated means at the $95 \%$ confidence level.

c LDL for plutonium-238 in surface water silt is $1.8 \times 10^{-\rightarrow} \mu \mathrm{Ci} / \mathrm{g}$.

d Suitable samples could not be obtained at Location 17.

* Sampling locations shown on Figure 4-4, p. 4-10. 


\subsubsection{Groundwater Trend Data}

Groundwater transit across the Mound Plant site generally proceeds west and southwest toward the Great Miami River. An extensive monitoring network has been installed to monitor the impact of site operations on the quality of the groundwater. As this network collects more data, more detailed analyses of long-term trends in groundwater constituents will be possible.
Currently, the best available trend data have been collected from the production wells used to . supply drinking water to the plant. Five-year trend data for tritium and plutonium-238 are shown in Figures 4-6 and 4-7, respectively. As seen in the figures, onsite tritium and plutonium-238 concentrations have exhibited only minor fluctuations over the period 1987 to 1991 . It is also evident from the figures that the levels of tritium and plutonium in the groundwater are far below DOE and EPA regulatory values.

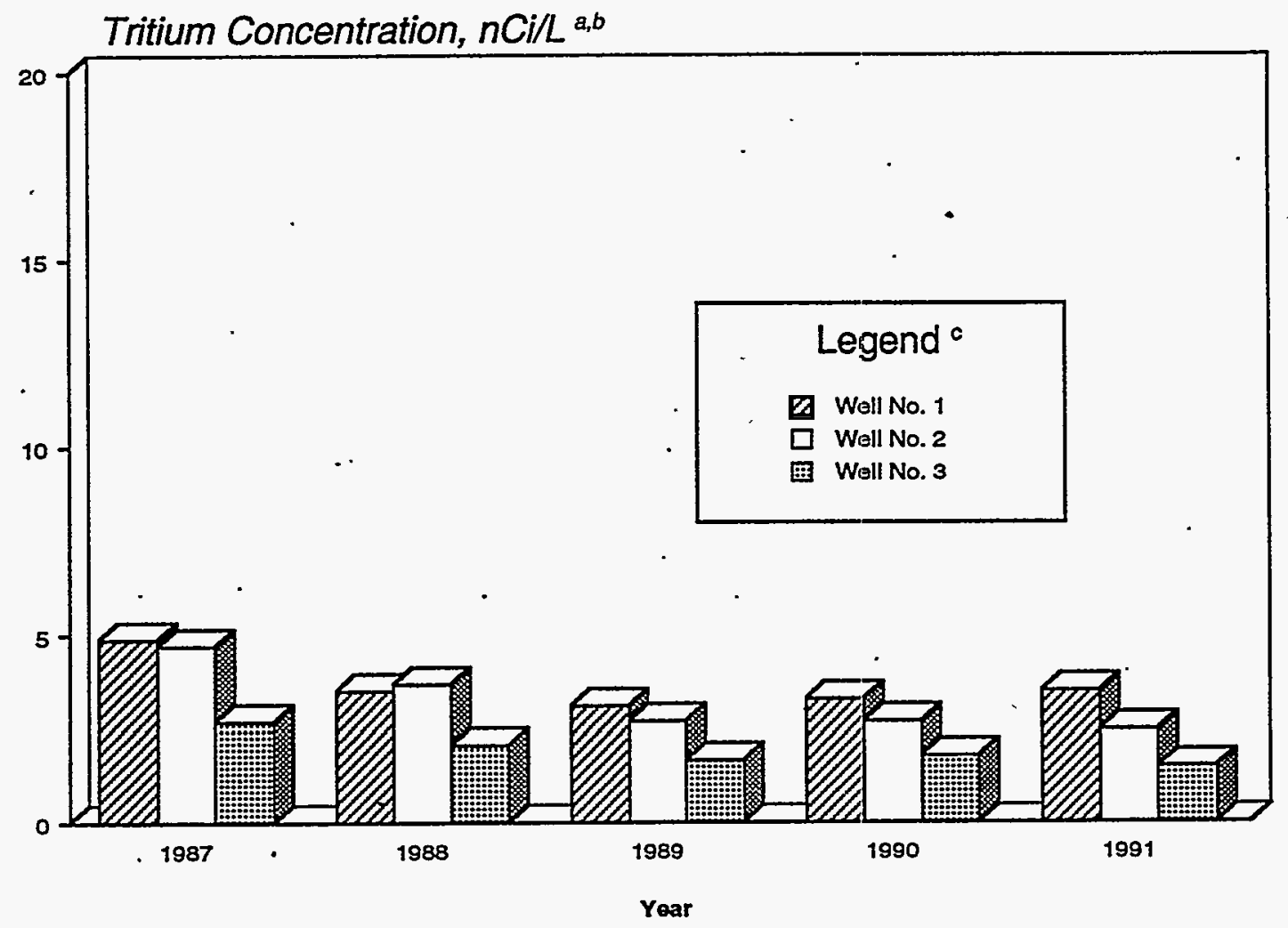

${ }^{a}$ Values shown in figure include average environmental levels.

${ }^{b}$ The EPA standard for tritium in drinking water is $20 \mathrm{nCi} / \mathrm{L}$.

c See Figure 4-5, p. 4-17 for well locations.

Figure 4-6. Annual average tritium concentrations in onsite production wells 


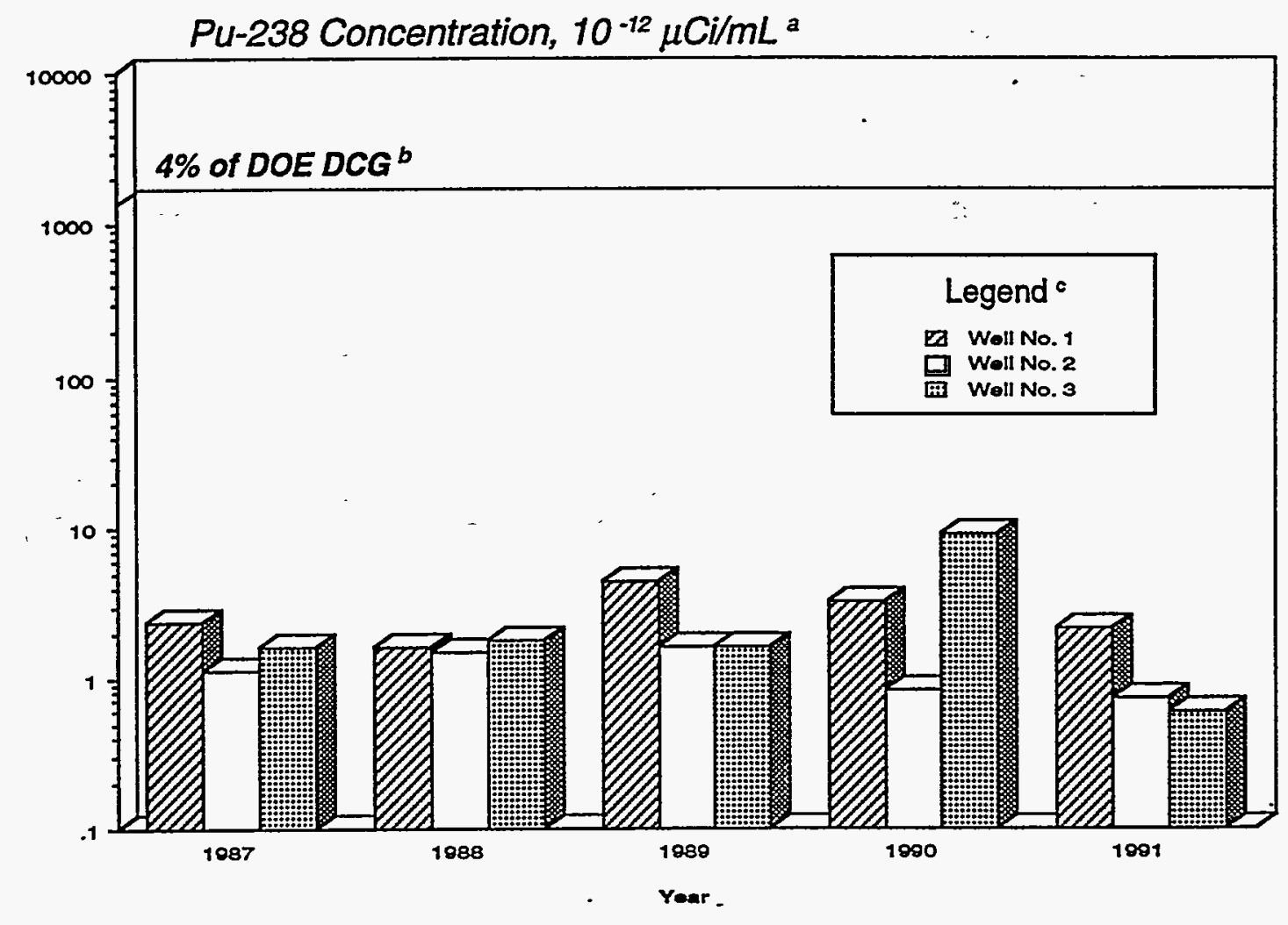

a Values shown in figure include average environmental levels.

b $1600 \times 10^{-12} \mu \mathrm{Ci} / \mathrm{mL}, 4 \%$ of the DOE DCG, corresponds to the DOE and EPA drinking water criterion of $4 \mathrm{mrem} / \mathrm{yr}$. .

c See Figure 4-5, p. 4-17, for well locations:

Figure 4-7. Annual average plutonium-238 concentrations in onsite production wells

\subsection{FOODSTUFFS AND VEGETATION}

\subsubsection{Description of Monitoring Program}

Various locally grown foodstuffs and vegetation samples are collected during the growing season from the surrounding area. Fish are collected from the Great Miami River. The intent of this aspect of the Environmental Monitoring Program is to determine whether plant and animal life are accumulating significant concentrations of radionuclides. Samples of grass, root crops, and tomatoes were collected in Miamisburg, Centerville, Bellbrook, Trotwood, Franklin, and Germantown (Figure 1-2). Fish were collected in the Great Miami River below a Mound discharge point. The plutonium-238 content of the foodstuff and vegetation samples is determined by ashing the samples, then proceeding with the same techniques used for plutonium analyses of air samples (Section 4.1.1.2). The tritium content of the foodstuff and vegetation samples is determined by distilling the water from the sample, then analyzing the distillate for tritium.

\subsubsection{Applicable Standards}

No standards apply.

\subsubsection{Results}

The results of the foodstuff, vegetation, and fish analyses are summarized in Tables 4-18 and 4-19. The concentration is given in terms of the sample weight (wet weight) before ashing or distilling. The samples of aquatic life analyzed included only the edible, fleshy portions of fish. 
Environmental levels (Table 3-2) for foodstuffs and vegetation have been subtracted from the data.

The average incremental concentrations of plutonium-238 in grass and potatoes did not exceed environmental levels. The average concentration of plutonium-238 in fish was $0.03 \times 10^{-9} \mu \mathrm{Ci} / \mathrm{g}$.
The average concentration of tritium was 0.15 $\times 10^{-6} \mu \mathrm{Ci} / \mathrm{g} \cdot$ in grass and $0.12 \times 10^{-6} \mathrm{Ci} / \mathrm{g}$ in tomatoes. These analyses show no evidence of any significant uptake by plant or animal life. Although concentrations of tritium in tomatoes collected in Miamisburg were higher than in those collected from other locations, the measured concentrations were extremely small.

Table 4-18. Incremental Plutonium-238 Concentrations ${ }^{a}$ in Foodstuffs and Vegetation in 1991

\begin{tabular}{|c|c|c|c|c|c|}
\hline \multirow[b]{2}{*}{ Location* } & \multirow{2}{*}{$\begin{array}{c}\text { Type } \\
\text { of } \\
\text { Sample }\end{array}$} & \multirow{2}{*}{$\begin{array}{c}\text { Number } \\
\text { of } \\
\text { Samples }\end{array}$} & \multicolumn{3}{|c|}{$\begin{array}{l}\text { Plutonium-238 } \\
\left(10^{-9} \mu \mathrm{Ci} / \mathrm{g}\right)\end{array}$} \\
\hline & & & Minimum & Maximum & Average ${ }^{b, c}$ \\
\hline \multirow[t]{2}{*}{ Miamisburg } & Grass & 4 & -0.21 & 0.7 & $0.22 \pm 0.83$ \\
\hline & Root Crops & 4 & -0.13 & 0.12 & $-0.04 \pm 0.38$ \\
\hline \multirow[t]{2}{*}{ Centerville } & Grass & 4 & $=0.21$ & -0.08 & $-0.15 \pm 0.36$ \\
\hline & Root Crops & 4 & -0.13 & 0.11 & $-0.01 \pm 0.37$ \\
\hline \multirow[t]{2}{*}{ Bellbrook } & Grass & 4 & -0.37 & 0.06 & $-0.11 \pm 0.47$ \\
\hline & Root Crops & 4 & 0.01 & 0.23 & $-0.08 \pm 0.37$ \\
\hline \multirow[t]{2}{*}{ Trotwood } & Grass & 4 & -0.27 & 0.04 & $-0.10 \pm 0.41$ \\
\hline & Root Crops & 4 & -0.14 & 0.06 & $-0.02 \pm 0.36$ \\
\hline \multirow[t]{2}{*}{ Franklin } & Grass & 4 & -0.27 & -0.07 & $-0.16 \pm 0.38$ \\
\hline & Root Crops & 4 & -0.29 & -0.09 & $-0.17 \pm 0.36$ \\
\hline \multirow[t]{2}{*}{ Germantown } & Grass & 4 & -0.41 & 0.3 & $-0.13 \pm 0.64$ \\
\hline & Root Crops & 4 & -0.15 & 0.02 & $-0.07 \pm 0 . \dot{35}$ \\
\hline \multirow{2}{*}{$\begin{array}{l}\text { Great Miami } \\
\text { River }\end{array}$} & Fish & 4 & -0.04 & 0.17 & $0.03 \pm 0.16$ \\
\hline & & & & & . \\
\hline
\end{tabular}

- Average environmental level (e.l.) found in Table 3-2 subtracted from the data.

b Error limits are estimates of the standard error of the estimated means at the $95 \%$ confidence level.

- LDL for plutonium-238 in grass is $0.9 \times 10^{-9} \mu \mathrm{Ci} / \mathrm{g}$. For plutonium-238 in root crops, the LDL is $0.6 \times 10^{-9} \mu \mathrm{Ci} / \mathrm{g}$. For plutonium-238 in fish, the LDL is $0.3 \times 10^{-9} \mu \mathrm{Ci} / \mathrm{g}$.

* Sampling locations for vegetation and crops are shown on Figure 1-1, p. 1-1. 


\section{Table 4-19. Incremental Concentration a of Tritium in Vegetation in 1991}

\begin{tabular}{|c|c|c|c|c|c|}
\hline \multirow[b]{2}{*}{ Location* } & \multirow{2}{*}{$\begin{array}{l}\text { Type } \\
\text { of } \\
\text { Sample }\end{array}$} & \multirow{2}{*}{$\begin{array}{c}\text { Number } \\
\text { of } \\
\text { Samples }\end{array}$} & \multicolumn{3}{|c|}{$\begin{array}{c}\text { Tritium } \\
\left(10^{-6} \mu \mathrm{Cj} / \mathrm{g}\right)\end{array}$} \\
\hline & & & Minimum & Maximum & Average ${ }^{b, c}$ \\
\hline \multirow{2}{*}{ Miamisburg } & Grass & 4. & 0.56 & 0.95 & $0.77 \pm 0.31$ \\
\hline & Tomatoes & 4 & 0.81 & 0.86 & $0.84 \pm 0.06$ \\
\hline \multirow[t]{2}{*}{ Centerville } & Grass & 4 & -0.12 & 0.07 & $0.01 \pm 0.22$ \\
\hline & Tomatoes & 4 & -0.07 & 0.03 & $-0.02 \pm 0.08$ \\
\hline \multirow[t]{2}{*}{ Bellbrook } & Grass & 4 & -0.17 & -0.05 & $-0.12 \pm 0.19$ \\
\hline & Tomatoes & 4 & -0.05 & 0.11 & $0.01 \pm 0.13$ \\
\hline \multirow[t]{2}{*}{ Trotwood } & Grass & 4 & -0.03 & 0.23 & $0.09 \pm 0.26$ \\
\hline & Tomatoes & 4 & -0.07 & 0.01 & $-0.04 \pm 0.07$ \\
\hline \multirow[t]{2}{*}{ Franklin } & Grass & 4 & -0.02 & 0.11 & $0.05 \pm 0.19$ \\
\hline & Tomatoes & 4 & -0.16 & 0.02 & $-0.05 \pm 0.13$ \\
\hline \multirow[t]{3}{*}{ Germantown } & Grass & 4 & 0.06 & 0.16 & $0.1 \pm 0.19$ \\
\hline & Tomatoes & 4 & -0.06 & 0.01 & $-0.02 \pm 0.07$ \\
\hline & & , & & & \\
\hline
\end{tabular}

average environmental level (e:1.) found in Table 3-2 subtracted from the data.

b Error limits are estimates of the standard error of the estimated means at the $95 \%$ confidence level.

c LDL for tritium in grass is $0.1 \times 10^{-6} \mu \mathrm{Ci} / \mathrm{g}$. For tritium in tomatoes, the $\mathrm{LDL}$ is $0.2 \times 10^{-6} \mu \mathrm{Ci} / \mathrm{g}$.

* Sampling locations shown on Figure 1-1, p. 1-1. 


\subsection{METHODS OF CALCULATING OFF- SITE RADIATION DOSE}

Exposure routes. Members of the public may receive radiation doses via various exposure pathways. For radionuclides discharged to the atmosphere, a person may inhale or be immersed in airborne radionuclides, may be exposed to radionuclides deposited on the ground, and may eat foods (e.g., millk, meat, vegetables, and produce) that contain radionuclides which have been deposited on, or taken up by, such foods. For radionuclides discharged to water, a person may drink water or eat fish that contain radionuclides. The other potential water exposure pathways (e.g., swimming and boating) add insignificantly to the doses.

Dose limits. Dose limits for members of the public were presented in Table E-2. The primary public dose-limits include consideration of all exposure modes. The primary dose limits are expressed as effective dose equivalents (EDEs), a term adopted by the International Commission on Radiological Protection (ICRP) for their riskbased system. The ICRP system relates the risk associated with irradiation of specific organs or tissues to the risks associated with uniform, wholebody irradiation. To make such comparisons possible, doses to organs and tissues are weighted and summed. The resultant figure-of-merit is the EDE.

Transport and dose models. Radionuclide releases from a facility, and the radiation doses which may result, are sometimes too small to be measured. Therefore, computer models are used to simulate the transport of radionuclides from the point of release and to calculate potential radiation doses to man. These calculations are made using computer codes recommended by appropriate regulatory agencies (e.g., the EPA). When available, site-specific data (source characteristics, release quantities, meteorological and climatological conditions, locations of people, and food production information) are used as input to the codes. When site-specific data are not available, conservative default data are used.
Methodology at Mound. The dose assessment techniques in use at Mound are performed according to DOEOrder 5400.5 . ForDOE reporting requirements, doses are presented as committed EDEs and total committed EDEs as defined in the Order. Specifically, the committed effective dose equivalent is the total dose equivalent that will be received by an individual over a 50-year time period as a result of one year of exposure to radionuclides; the total committed EDE reported is the sum of the committed effective dose equivalents from the air, water, and foodstuffs pathways. Mound personnel calculate committedEDEs from exposure to measured concentrations of plutonium-238 and tritium in air, water, and vegetation. These values are then summed to estimate the total committed EDE to an individual at the site boundary. The results for 1991 are shown in Table E-3. The results in Table E-3 were based on maximum average concentrations and conservative exposure assumptions; they therefore represent maximum dose estimates for Mound.

In calculating doses, some assumptions must be made about the radionuclides. The solubility of ingested or inhaled plutonium-238 in the receptor is unknown. However, it is highly probable that most of the plutonium-238 is in the oxide form, which is very insoluble. Most of the solid form of plutonium-238 processed at Mound was either oxide or hydroxide used in encapsulated heat sources. There was some solution processing, primarily in recovery operations in reclaiming scrap material. In order to provide a realistic but conservative estimate, it is assumed that $50 \%$ of the inhaled plutonium-238 is soluble (class W) and $50 \%$ is insoluble (class $Y$ ). It is also assumed that ingested plutonium-238 is $50 \%$ soluble and $50 \%$ insoluble. All dose assessments from monitoring data for tritium are based on the oxide form. Tritium oxide is used because the DOE DCG for tritium oxide is 25,000 times lower than that of the elemental form of tritium. Using the DCG for tritium oxide in all dose calculations results in a more conservative estimate of the impact of Mound's operations. 
DOE Order 5400.5 also requires compliance with applicable EPA regulations. To demonstrate compliance with the EPA's NESHAPs requirements (40 CFR 61, Subpart H), Mound performs additional transport and dose calculations each year. As required by NESHAPs, Mound uses the computer code CAP-88 to calculate doses from airborne releases. Stack release data for tritium, isotopes of plutonium, and isotopes of uranium (Table E-1) were used along with meteorological data from Mound as input to CAP-88.

Comparisons of results. Using measured concentrations, the committed EDE to the maximally exposed individual from airborne releases of tritium and plutonium-238 was 0.14 mrem $(0.0014 \mathrm{mSv})$. Based on the CAP-88 output, the maximum EDE from all airborne releases was $0.08 \mathrm{mrem}(0.0008 \mathrm{mSv})$. These two methods of estimating the committed EDE were in reasonable agreement. Both estimates were less than $2 \%$ of NESHAPs standard of $10 \mathrm{mrem} / \mathrm{yr}(0.1 \mathrm{mSv} /$ yr) for the air pathway.

Using the larger of these estimates $(0.14 \mathrm{mrem}$; $0.0014 \mathrm{mSv}$ ), the total committed EDE to the maximally exposed individual, including the ingestion of water $(0.06 \mathrm{mrem} ; 0.0006 \mathrm{mSv})$, was $0.28 \mathrm{mrem}(0.0028 \mathrm{mSv})$ from all pathways (Table E-3). This dose is less than $1 \%$ of the DOE dose standard of $100 \mathrm{mrem}(1.0 \mathrm{mSv})$ from all pathways for prolonged exposure.

Population impacts. The collective committed EDE, as used in this report, is the sum of the committed EDEs of all individuals in the population within $80 \mathrm{~km}$ of Mound. This collective committed EDE is calculated using the committed EDE from the CAP-88 model and the committed EDE calculated from ingestion of well water with concentrations measured in various communities surrounding Mound.

The estimated committed EDE to the 3,034,679 persons living within $80 \mathrm{~km}$ of Mound was 3.6 person-rem ( 0.036 person-Sv) from Mound's operation during 1991. To put this in perspective, a population of this size would receive approximately 1 million person-rem (10,000 person-Sv) from natural sources (300 mrem; $3.0 \mathrm{mSv}$ per person). 


\section{ENVIRONMENTAL NONRADIOLOGICAL PROGRAM INFORMATION}

Summary: Particulate concentrations measured at Mound's onsite and offsite air-sampling sites indicateno influence from Mound operations. Mound's liquid effluentswere monitored for a number of organic and inorganic nonradiological substances. Mound did not exceed NPDES permit limits during 1991.

\subsection{AIR MONITORING PROGRAM}

\subsubsection{Description of Program}

Mound has six state air permits from OEPA. A number of other sources are registered with RAPCA. The primary source of nonradiological airborne emissions is the Mound steam power plant. This plant is normally fueled with natural gas but can burn fuel oil. Fuel oil with $1 \%$ sulfur content is burned during unusually cold weather or if the natural gas supply to Mound is interrupted. Approximately 82,640 liters (21,830 gal) of fuel oil were burned during 1991 .
There are three additional major sources of airborne emissions at Mound. A paint spray booth is operated intermittently in the Mound paint shop. Wastes from operations involving explosives are disposed of by open burning under a permit issued by RAPCA and in compliance with RCRA requirements (40 CFR 265.382). Fire-fighter training exercises are held at an open outdoor facility under a burning permit issued by RAPCA.

Nonradiological airborne emissions for 1991 are summarized in Table 5-1.

Table 5-1. Nonradiological Airborne Effluent Data for 1991

\begin{tabular}{llccc}
\hline $\begin{array}{c}\text { Emission } \\
\text { Source }\end{array}$ & Pollutant & Emission & $\begin{array}{c}\text { Emission } \\
\text { Standard }\end{array}$ & $\begin{array}{c}\text { \% of } \\
\text { Standard }\end{array}$ \\
\hline Powerhouse & Particulates & $\begin{array}{c}0.006 \mathrm{lbs} / 10^{6} \\
\text { BTU input }\end{array}$ & $\begin{array}{c}0.02 \mathrm{lbs} / 10^{6 \mathrm{a}} \\
\text { BTU input }\end{array}$ & $\begin{array}{c}\text { B } \\
\text { Powerhouse }\end{array}$ \\
Sulfur Oxides & $\begin{array}{c}0.002 \mathrm{lbs} / 10^{6} \\
\text { BTU input }\end{array}$ & $\begin{array}{c}1.6 \mathrm{lbs} / 10^{60} \\
\text { BTU input }\end{array}$ & 0.13 \\
Paint Shop & Organics & $270 \mathrm{lbs}$ & $5,000 \mathrm{lbs} / \mathrm{y} \mathrm{c}$ & 5.4 \\
Explosives Burning & Particulates & $17.9 \mathrm{lbs}$ & $\mathrm{d}$ & $\mathrm{d}$ \\
Fire Fighter Training & Particulates & $3.8 \mathrm{lbs}$ & $\mathrm{d}$ & $\mathrm{d}$ \\
\hline
\end{tabular}

2 OEPA Regulation 3745-17-10.

'OEPA Regulation 3745-18-06.

'Conditions of Mound's permit.

$₫$ Not applicable. 


\subsubsection{Results}

Particulate concentrations (Table 5-2) were calculated from samples collected at the 15 offsite and 5 onsite sampling locations. The State of Ohio Ambient Quality Standard for airbome particulates is referenced in the Table for comparison purposes.
Nonradioactive airborne emissions at Mound had minimal impact on ambient air quality. Particulate concentrations measured onsite fall within the same range as those measured offsite. Particulate concentration also appears independent of distance from Mound. This result suggests that Mound's particulate contribution to the surrounding area is negligible.

Table 5-2. 1991 Particulate Concentrations

\begin{tabular}{|c|c|c|c|}
\hline Sampling & $\begin{array}{c}\text { Number } \\
\text { of }\end{array}$ & $\begin{array}{c}\text { Particulates } \\
\left(\mu \mathrm{g} / \mathrm{m}^{3}\right)\end{array}$ & $\begin{array}{c}\text { Annual }^{\mathrm{b}} \\
\text { Arithmetic } \\
\text { Average }\end{array}$ \\
\hline Location* & Samples & Minimum & $\left(\mu \mathrm{g} / \mathrm{m}^{3}\right)$ \\
\hline
\end{tabular}

Qffsite

$\begin{array}{rrrrr}101 & 52 & 20 & 66 & 41 \pm 3 \\ 102 & 52 & 17 & 54 & 30 \pm 2 \\ 103 & 51 & 17 & 83 & 30 \pm 3 \\ 104 & 52 & 23 & 59 & 38 \pm 2 \\ 105 & 52 & 15 & 56 & 31 \pm 3 \\ 108 & 52 & 61 & 40 \pm 2 \\ 110 & 52 & 14 & 49 & 28 \pm 2 \\ 111 & 51 & 15 & 138 & 57 \pm 8 \\ 112 & 52 & 16 & 51 & 30 \pm 2 \\ 115 & 52 & 19 & 106 & 44 \pm 6 \\ 118 & 52 & 14 & 53 & 26 \pm 2 \\ 119 & 52 & 18 & 66 & 33 \pm 3 \\ 122 & 52 & 16 & 78 & 34 \pm 4 \\ 123 & 52 & 19 & 61 & 34 \pm 2 \\ 124 & 52 & 16 & 64 & 32 \pm 3\end{array}$

Onsite

$\begin{array}{lllll}211 & 52 & 20 & 75 & 38 \pm 3 \\ 212 & 50 & 11 & 52 & 29 \pm 3 \\ 213 & 52 & 20 & 97 & 44 \pm 4 \\ 214 & 52 & 13 & 56 & 30 \pm 3 \\ 215 & 51 & 13 & 59 & 30 \pm 3\end{array}$

- Ohio Ambient Air Quality Standard $=60 \mu \mathrm{g} / \mathrm{m}^{3}$ (annual geometric average).

- Enror limits are estimates of the standard error of the estimated means at the $95 \%$ confidence level.

* Offsite sampling locations shown on Figure 42, p. 4-3.

Onsite sampling locations shown on Figure 4-1, p. 4-2. 


\subsection{SURFACE WATER MONITORING PROGRAM}

\subsubsection{Description of Monitoring Program}

Mound discharged an average of 2.65 million liters ( 0.70 million gallons) of water per day in 1991 to the Great Miami River. An NPDES permit regulates nonradioactive pollutants in this effluent water. On March 27, 1991, Mound applied for renewal of its NPDES permit, and reissue of the permit is expected in the second quarter of 1992. The NPDES permit requires Mound to characterize its effluent by analyzing samples collected at four onsite locations: 5601, 5602, 5603, and 5002 (Figure 4-3). Flow-proportional, 24-hour composite samples and grab samples are collected from discharges 5601,5602 , and 5002 as required by the permit. Discharge 5601 contains the effluent from the sanitary sewage treatment plant. Discharge 5602 includes storm water runoff, single-pass cooling water, cooling tower blowdown, zeolite softener backwash, and discharge from the radioactive waste disposal facility. Discharge 5002 consists of softener backwash, and most of the plant storm water runoff. A time-proportional, composite sample and a grab sample are collected from the electroplating facility effluent, discharge 5603 , as required by the permit. NPDES permit limits can be found in Table 5-3. The NPDES monitoring program used methods specified in the Clean Water Act Regulations, 40 CFR 136.

The NPDES permit requires quarterly analyses of the electroplating effluent (5603) for Total Toxic Organics (TTO), the organic subset of Priority Pollutants. Additionally, Mound performs quarterly TTO monitoring of 5601, 5602, and 5002, which is not an NPDES requirement. A summary of organic compounds that were detected at least once is given in Table 5-4 for each outfall.

The permit requires monthly monitoring of $\mathrm{pH}$ from the water discharged from one offsite well, location number 5604 (Figure 4-3). In 1991, this well was pumped for 6 days and discharged a total of 3.51 million gallons. The measured $\mathrm{pH}$ of this discharge was $7.2 \mathrm{pH}$ units. This well is used to dilute tritium concentrations in groundwater and has been operated in conjunction with the Potable Water Project (Dames and Moore August 1976).

A total of 1010 samples were analyzed for NPDES parameters during 1991.

\subsubsection{Applicable Standards}

Standards applicable to nonradioactive materials and physical properties in Mound wastewater discharges are contained in Mound's NPDES permit as administered by OEPA. Monitoring requirements and standards are listed in permit NP1-I-000005CD, Application No. OH009857.

\subsubsection{Results}

In 1991, Mound did not exceed NPDES permit limits.

Data from the U.S. Geological Survey show that flow in the Great Miami River at Miamisburg in 1991 averaged 2156 million gallons per day (MGD), with a minimum and a maximum of 223 MGD and 22,739 MGD, respectively. The magnitude of this river flow is significantly greater than Mound effluents. Mound effluents did not affect the Great Miami River and its compliance with stream standards. 
Table 5-3. National Pollutant Discharge Elimination System Data for 1991

\begin{tabular}{|c|c|c|c|c|c|c|c|c|}
\hline \multirow[t]{2}{*}{ - } & \multirow[b]{2}{*}{$\begin{array}{l}\text { No. of } \\
\text { Samples }\end{array}$} & \multirow[b]{2}{*}{ Minimum } & \multirow[b]{2}{*}{ Maximum } & \multirow[b]{2}{*}{$\begin{array}{l}\text { Annual } \\
\text { Average }\end{array}$} & \multirow{2}{*}{$\begin{array}{l}\text { Maximum } \\
\text { Monthly } \\
\text { Average }\end{array}$} & \multicolumn{3}{|c|}{ NPDES Permit Limits } \\
\hline & & & & & & Daily & $\begin{array}{l}\text { Weekly } \\
\text { Average }\end{array}$ & $\begin{array}{l}\text { Monthly } \\
\text { Average }\end{array}$ \\
\hline \multicolumn{9}{|l|}{ DISCHARGE 5601 PARAMETERS ${ }^{2}$} \\
\hline Flow Rate, MGD & Cont. $^{b}$ & 0.03 & 0.15 & 0.08 & 0.10 & $n / a^{c}$ & $\mathrm{n} / \mathrm{a}$ & $\mathbf{n} / \mathbf{a}$ \\
\hline pH, s.u. & 220 & 7.4 & 8.1 & 7.7 & 7.9 & $6.5-9.0$ & $\mathrm{n} / \mathrm{a}$ & $\mathrm{n} / \mathrm{a}$ \\
\hline Biochemical Oxygen Demand, $\mathrm{mg} / \mathrm{L}$ & 102 & 0.1 & 9.6 & 1.6 & 3.2 & $\mathrm{n} / \mathrm{a}$ & 15.0 & 10.0 \\
\hline Suspended Solids, mg/L & 102 & 0.5 & 14.9 & 2.6 & 5.6 & $\mathrm{n} / \mathrm{a}$ & 30.0 & 15.0 \\
\hline Fecal Coliform, $\mathrm{N} / 100 \mathrm{~mL}$ & 27 & 1 & 500 & 36 & 149 & $\mathbf{n} / \mathbf{a}$ & 2000 & 1000 \\
\hline Escherichia Coli, $\mathrm{N} / 100 \mathrm{~mL}$ & 6 & $<1$ & 110 & 22 & 110 & $\mathrm{n} / \mathbf{a}$ & $\mathbf{n} / \mathbf{a}$ & $\mathrm{n} / \mathrm{a}$ \\
\hline Residual Chlorine, mg/L & 106 & 0.10 & 0.46 & 0.21 & 0.30 & $\mathrm{n} / \mathrm{a}$ & 0.5 & $\mathbf{n} / \mathbf{a}$ \\
\hline Oil \& Grease, $\mathrm{mg} / \mathrm{L}$ & 4 & $<1.0$ & 1.5 & 1.1 & 1.5 & $n / a$ & $\mathrm{n} / \mathrm{a}$ & $\mathrm{n} / \mathrm{a}$ \\
\hline Ammonia, $\mathrm{mg} / \mathrm{L}$ as $\mathrm{N}$ & 24 & 0.03 & 10.28 & 1.27 & 4.46 & $\mathrm{n} / \mathrm{a}$ & $\mathrm{n} / \mathrm{a}$ & $\mathbf{n} / \mathbf{a}$ \\
\hline Cadmium, $\mu g / L$ & 2 & $<10$ & $<10$ & $<10$ & $<10$ & $\mathrm{n} / \mathrm{a}$ & $\mathrm{n} / \mathrm{a}$ & $\mathbf{n} / \mathbf{a}$ \\
\hline Chromium, $\mu \mathrm{g} / \mathrm{L}$ & 2 & $<50$. & $<50$ & $<50$ & $<50$ & $n / a$ & $\mathrm{n} / \mathrm{a}$ & $\mathbf{n} / \mathbf{a}$ \\
\hline Copper, $\mu g / L$ & 2 & 71 & 87 & 79 & 87 & $\mathrm{n} / \mathrm{a}$ & $\mathrm{n} / \mathrm{a}$ & $\mathbf{n} / \mathbf{a}$ \\
\hline Nickel, $\mu g / L$ & 2 & $<50$ & $<50$ & $<50$. & $<50$ & $\mathrm{n} / \mathrm{a}$ & $\mathrm{n} / \mathrm{a}$ & $\mathrm{n} / \mathrm{a}$ \\
\hline Zinc, $\mu g / L$ & 2 & $<50$ & 104 & 77 & 104 & $\mathbf{n} / \mathbf{a}$ & n/a. & $\mathbf{n} / \mathbf{a}$ \\
\hline Lead, $\mu g / L$ & 2 & $<50$ & $<50$ & $<50$ & $<50$ & $\mathrm{n} / \mathrm{a}$ & $\mathrm{n} / \mathrm{a}$ & $\mathbf{n} / \mathbf{a}$ \\
\hline Mercury, $\mu g / L$ & 2 & $<0.2$ & $<0.2$ & $<0.2$ & $<0.2$ & $\mathrm{n} / \mathrm{a}$ & $\mathrm{n} / \mathrm{a}$ & $\mathbf{n} / \mathbf{a}$ \\
\hline \multicolumn{9}{|l|}{ DISCHARGE 5602 PARAMETERS } \\
\hline Flow Rate, MGD & Cont. & 0.00 & 0.56 & 0.12 & 0.14 & n/a & $\mathbf{n} / \mathbf{a}$ & $\mathrm{n} / \mathrm{a}$ \\
\hline Chemical Oxygen Demand, $\mathrm{mg} / \mathrm{L}$ & 51 & 3 & 421 & 100 & 178 & $\mathbf{n} / \mathbf{a}$ & $\mathrm{n} / \mathrm{a}$ & $\mathrm{n} / \mathrm{a}$ \\
\hline Suspended Solids, mg/L & 51 & 0.4 & 34.9 & 8.8 & 13.8 & 45 & $\mathbf{n} / \mathbf{a}$ & 30 \\
\hline Oil \& Grease, $\mathrm{mg} / \mathrm{L}$ & 12 & $<1.0$ & $<1.0$ & $<1.0$ & $<1.0$ & 10 & $\mathbf{n} / \mathbf{a}$ & $\mathrm{n} / \mathrm{a}$ \\
\hline $\mathrm{pH}$, s.u. & 51 & 7.4 & 8.7 & 8.4 & - 8.5 & $6.5-9.0$ & $\mathrm{n} / \mathrm{a}$ & $\mathrm{n} / \mathrm{a}$ \\
\hline \multicolumn{9}{|l|}{ DISCHARGE 5603 PARAMETERS } \\
\hline $\mathrm{pH}$, s.u. & 22 & 7.0 & 7.4 & 7.2 & 7.2 & $6.5-9.0$ & $\mathbf{n} / \mathbf{a}$ & $\mathbf{n} / \mathbf{a}$ \\
\hline Cyanide, mg/L & 22 & $<0.1$ & $<0.1$ & $<0.1$ & $<0.1$ & 1.0 & $n / a$ & 0.65 \\
\hline Cadmium, $\mu g / L$ & 22 & $<10$ & $<10$ & $<10$ & $<10$ & 100 & $n / a$ & $\mathbf{n} / \mathbf{a}$ \\
\hline Chromium, $\mu g / L$ & 22 & $<50$ & $<50$ & $<50$ & $<50$ & 500 & $\mathrm{n} / \mathrm{a}$ & $\mathrm{n} / \mathrm{a}$ \\
\hline Copper, $\mu g / L$ & 22 & 60 & 368 & 167 & 324 & 500 & $\mathrm{n} / \mathrm{a}$ & $\mathbf{n} / \mathbf{a}$ \\
\hline Nickel, $\mu g / L$ & 22 & $\infty 0$ & 55 & $<50$ & $<0$ & 500 & $\mathrm{n} / \mathrm{a}$ & $\mathbf{n} / \mathbf{a}$ \\
\hline Total Toxic Organics, mg/L & 4 & $<1.0$ & $<1.0$ & $<1.0$ & $<1.0$ & 2.13 & $n / a$ & $n / a$ \\
\hline \multicolumn{9}{|l|}{ DISCHARGE 5002 PARAMETERS } \\
\hline Flow Rate, MGD & Cont. & 0.00 & 2.38 & 0.50 & 0.86 & $\mathbf{n} / \mathbf{a}$ & $\mathrm{n} / \mathrm{a}$ & $\mathrm{n} / \mathrm{a}$ \\
\hline Suspended Solids, $\mathrm{mg} / \mathrm{L}$ & 51 & 4.0 & 42.8 & 14.0 & 19.1 & 45 & $\mathrm{n} / \mathrm{a}$ & 30 \\
\hline $\mathrm{pH}$, s.u. & 51 & 7.9 & 9.0 & 8.4 & 8.5 & $6.5-9.0$ & $\mathrm{n} / \mathrm{a}$ & $\mathrm{n} / \mathrm{a}$ \\
\hline
\end{tabular}

2 The maximum and minimum values for Biochemical Oxygen Demand, Residual Chlorine, and Suspended Solids are weekly average values for discharge 5601 .

${ }^{b}$ Cont. = Continuous

$e_{n} / a=$ Not applicable. No permit limits. 
Table 5-4. Summary of Organic Compounds Detected in Mound Effluents in 1991

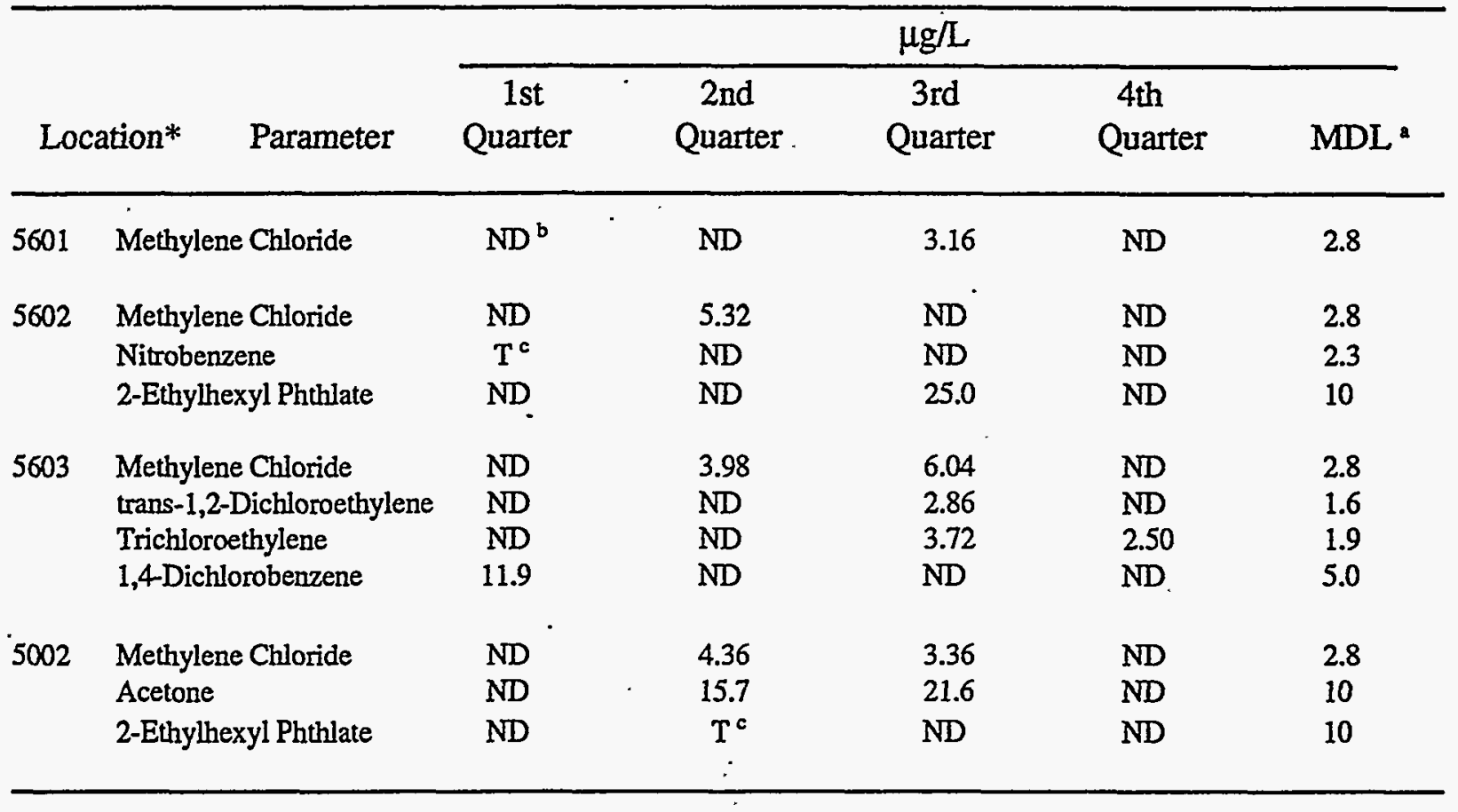

"Method Detection Limit

${ }^{b} \mathrm{ND}$ - None detected

' $\mathrm{T}$ - Trace detected, below EPA's MDL

* Sampling locations shown on Figure 4-3, p. 4-9.

\subsection{ENVIRONMENTAL OCCURRENCES}

Under CERCLA and the Clean Water Act, reportable quantity $(R Q)$ levels have been established for designated hazardous substances. If a spill or other inadvertent release to the environment exceeds the $R Q$, immediate notification of the appropriate federal agencies (e.g., National Response Center, EPA, or the Coast Guard) is required. No such releases occurred at Mound during 1991.

\subsection{SUBMISSIONSUNDERSARA TITLE III}

Title III of the Superfund Amendments and Reauthorization Act (SARA) addresses the emergency planning and community right-to-know re- sponsibilities of facilities handling hazardous materials. To meet the requirements of Sections 311 and 312 of Title III, for 1991 Mound reported storing and/or utilizing three "extremely hazardous" substances and 12 "hazardous" substances in quantities subject to regulation under the Act. Those subtstances are identified in Table 5-5.

Mound also reviewed Plant toxic chemical data for 1991 to evaluate compliance with Section 313 of Title $\mathrm{II}$. That review revealed no reportable releases of chemicals on the EPA Toxic Chemical List. Mound further determined that no chemicals used onsite met the List's "otherwise used" and "reportable threshold" limits. Though no specific reports are required of the facility under Section 313, Mound continues to develop comprehensive up-to-date inventories of all hazardous materials managed onsite. 
Table 5-5. Emergency and Hazardous Chemical Inventory Data for Mound

Hazardous Chemicals

Diesel fuel

No. 2 fuel oil

Ferric chloride

Sodium hydroxide
Nitrogen, liquid

Helium, liquid

Gasoline, unleaded

Argon, liquid
Isopropyl alcohol

Ethylene glycol

Calcium chloride

Ethyl alcohol

Extremely Hazardous Chemicals

Ammonia

- Sulfuric acid

Nitric acid 


\section{GROUNDWATER PROGRAM}

Summary: Monitoring wells were sampled and analyzed for volatile organics; semivolatile organics or BNA; pesticides and PCBs; explosives; metals; inorganic cations; inorganic anions; and radionuclides. Preliminary interpretation of the groundwater monitoring data indicates that VOCs are the primary contaminants of concern.

\subsection{HYDROLOGY AT MOUND}

Groundwater conditions at Mound vary with the positions of different materials and their corresponding hydraulic properties. Virtually impermeable bedrock underlies all but the first few feet of the hilltop and hillside areas. Although the rock itself is impervious, very small quantities of groundwater seep through joints and weathered cracks. The upper $6 \mathrm{~m}(20 \mathrm{ft})$ of bedrock, where chemical weathering allows enlargement of cracks, is the most permeable. Permeability of the upper $6 \mathrm{~m}$ ( $20 \mathrm{ft}$ ) of bedrock is estimated to range from 40 to $400 \mathrm{~L} /$ day $/ \mathrm{m}^{2}$ ( 1 to $10 \mathrm{gpd} / \mathrm{ft}^{2}$ ). Below this depth, bedrock permeability generally rangesfrom 0 to $8 \mathrm{~L} /$ day $/ \mathrm{m}^{2}\left(0.0\right.$ to $\left.0.2 \mathrm{gpd} / \mathrm{ft}^{2}\right)$.

Hydraulic properties of the glacial till soils that form a veneer over the entire site vary and depend on the relative proportions of fine- to coarsegrained material at any given location. Values of permeability normally range from 0.0041 to 0.041 $\mathrm{L} /$ day $/ \mathrm{m}^{2}\left(0.0001\right.$ to $\left.0.001 \mathrm{gpd} / \mathrm{ft}^{2}\right)$, although values up to $2.8 \mathrm{~L} / \mathrm{day} / \mathrm{m}^{2}\left(0.007 \mathrm{gpd} / \mathrm{ft}^{2}\right)$ were measured in the upper weathered zones. Below the glacial till in the lower valley area is a zone of glacial outwash composed of sand and gravel. The permeability of this zone is estimated to range from 40,700 to $81,000 \mathrm{~L} / \mathrm{day} / \mathrm{m}^{2}(1,000$ to $2,000 \mathrm{gpd} /$ $\left.\mathrm{ft}^{2}\right)$. This horizon forms the eastern edge of the Buried Valley Aquifer (BVA) and extends under the Great Miami River to the west. Three onsite wells draw water from this aquifer. The BVA was designated a sole-source aquifer by the EPA during 1989. Water levels under the facility are ultimately controlled by the level of the Great Miami River, which has a non-flood level at elevation $208 \mathrm{~m}$ (682 ft).

\subsubsection{Major Aquifers}

Municipal and industrial water supplies in the vicinity of the site depend upon high-capacity wells drilled into unconsolidated sand and gravel aquifers. Buried valleys that trend in the general position of the present Great Miami River and its tributaries contain 30 to $61 \mathrm{~m} \overline{(100}$ to $200 \mathrm{ft})$ of Pleistocene sand, gravel, and fine-grained till and form the principal aquifer in the area. Good domestic groundwater supplies are available in upland areas which are blanketed by granular glacial deposits or deposits of granular soils interbedded within relatively impermeable till. A map showing hydrogeologic environments for a radius of $4.0 \mathrm{~km}(2.5 \mathrm{mi})$ from the site is presented in Figure 6-1. Industrial wells adjacent to the site have specific capacities ranging from 15 to $45 \mathrm{~L}$ $\mathrm{sec} / \mathrm{m}$ (73 to $218 \mathrm{gpm} / \mathrm{ft}$ ) of drawdown. Specific capacities as high as $281.5 \mathrm{~L} / \mathrm{sec} / \mathrm{m}$ (1360 gpm/ft) of drawdown have been reported for a well at Chautauqua, about $2.4 \mathrm{~km}(1.5 \mathrm{mi})$ south of the site.

. Recharge to aquifers is available from three major sources:

- direct infiltration from the GreatMiami River,

- leakage along valley walls at the bedrockoutwash contact, and

- induced infiltration caused by hydraulic sinks due to pumping.

Recharge to the portion of the aquifer underlying the Mound Plant is primarily derived from direct infiltration from the Great Miami River and by precipitation and leakage from valley walls. This source of recharge is sufficient in quantity to balance withdrawals. 




Figure 6-1. Hydrogeologic environments in the vicinity of Mound 
The BVA, located immediately west of the Mound Plant and below an elevation of approximately $213 \mathrm{~m}(700 \mathrm{ft})$, is the major aquifer adjacent to the site. Within the limits of the property; the maximum known thickness of the aquifer is about $21 \mathrm{~m}(70 \mathrm{ft})$ at the extreme southwest corner of the site. The aquifer reaches a maximum thickness of about $46 \mathrm{~m}$ (150 ft) near the river channel and is oriented in a north-south direction, in coincidence with the course of the Great Miami River. Recharge by induced stream infiltration occurs, although the sand and gravel aquifer at this location contains extensive interstratified layers of clayish till which impede infiltration. The BVA west of the site is estimated to be capable of producing 35 to 47 million liters per day per kilometer (15 to 20 million gallons of groundwater per day per linear mile) of valley.

There are no perennial streams on the site. A drainage basin is associated with the deep valley which separates the two high areas, but it is generally confined to the site area. Since the drainage basin is relatively small and the slopes are relatively steep, runoff through site drainage features is rapid and does not pose a threat to facility structures.

\subsubsection{Movement of Groundwater}

Groundwater in the area generally flows south, following the downstream course of the Great Miami River. Groundwater levels experience local reversals in areas of heavy pumpage, which are expected to increase in both number and area as regional groundwater development increases. in the future. Although the BVA is generally overdrawn between West Carrollton and Dayton, relocation of well fields and artificial recharge through the use of infiltration lagoons will probably reduce the magnitude of groundwater gradient reversals within a few years. Currently, no evidence indicates that the regional gradient is reversed south of the city of West Carrollton. At Miamisburg, pumping does not influence the natural groundwater gradient except locally near individual well fields.

\subsubsection{Uses of Groundwater in the Vicinity}

There are six major public water supplies and numerous industrial users within an 8-km (5-mi) radius of Mound Plant. The locations of public and private water supply wells and distribution areas for municipal water service are shown in Figure 6-2. A tabulation of current and projected water demands is presented in Table 6-1.

The only industrial user within $8 \mathrm{~km}(5 \mathrm{mi})$ downstream is the O. H. Hutchings Power Generating Station. Industrial groundwater users located north (upstream) of the site are isolated from the facility area by hydraulic barriers.

Miamisburg owns ten water wells into the aquifer, but only those on the west side of the river are in use. All operational city wells are separated from the site by a minimum straight-line distance of over $0.8 \mathrm{~km}(0.5 \mathrm{mi})$.

Figure 6-2 shows the areas close to Mound in which some users may obtain their water from private wells. There is, therefore, a possibility that some of the waterused to charge private wells originates in the runoff from the Mound Plant site. Low levels of tritium in this runoff have caused a slight but measurable increase above background in the tritium content. Private wells in the other areas defined on Figure 6-2 have not shown any increases in tritium content above normal background. Measurements have shown the concentrations to be less than $1.0 \%$ of the EPA drinking water standard of $20 \mathrm{nCi} / \mathrm{L}$.

Wells located on the DOE property at Mound supply water to the plant site. Present water usage of the facility ranges from 19 to 32 liters/second (300 to 500 gallons per minute). The water withdrawn from the wells is partially replenished by induced stream infiltration from the Great Miami River and by precipitation. The estimated maximum capacity of the water system exceeds the maximum water usage. However, a reserve water supply having a capacity of 63 liters/second (1,000 gallons per minute) is available from the City of Miamisburg in case of an emergency. 


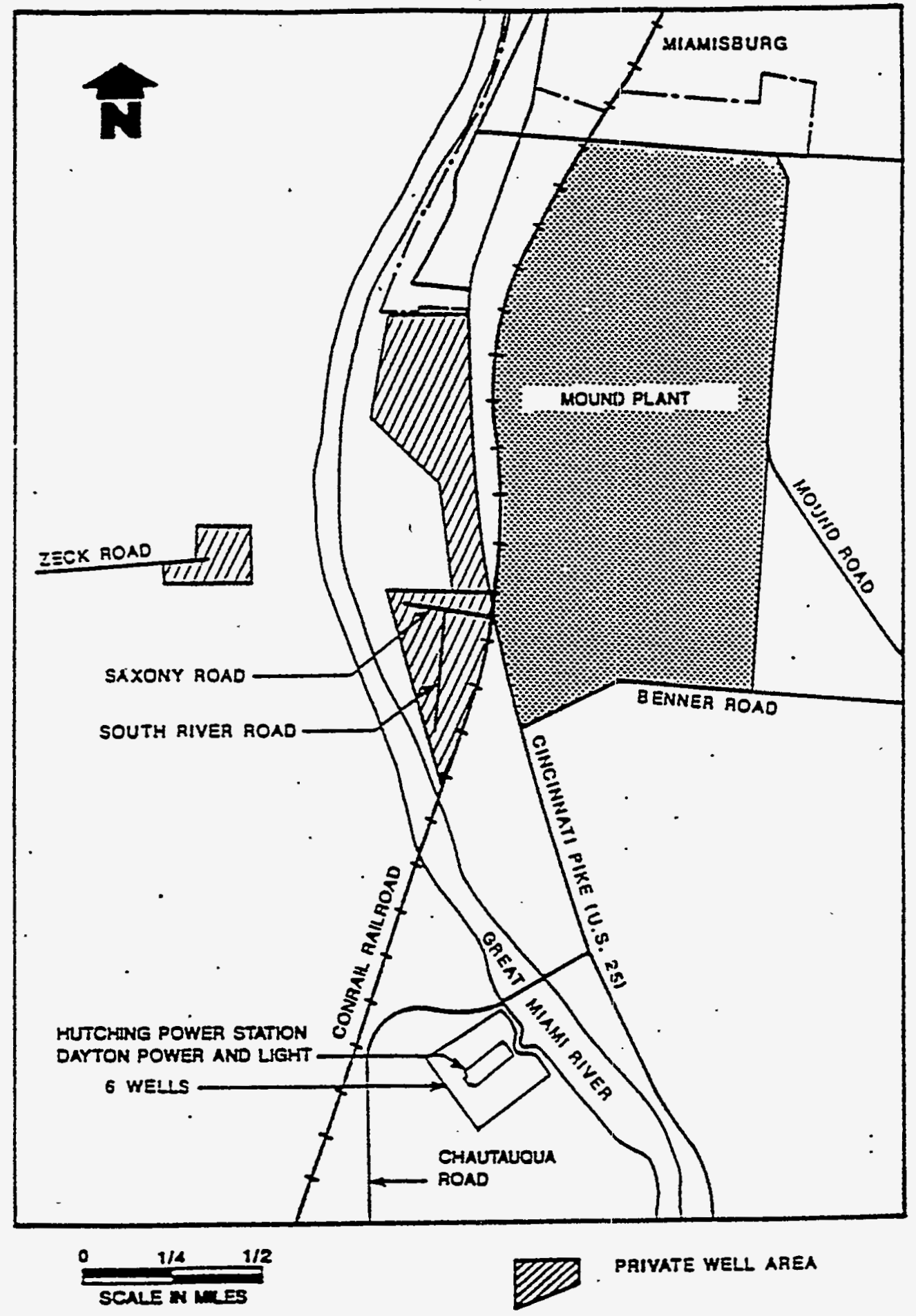

Figure 6-2. Municipal and private well fields near Mound 
Table 6-1. Municipal Groundwater Use Within the Great Miami River Watershed

\begin{tabular}{|c|c|c|c|c|}
\hline Municipal Supplies & $\begin{array}{c}\text { Upstream (U) or } \\
\text { Downstream (D) of } \\
\text { Site }\end{array}$ & $\begin{array}{c}\text { Average } \\
\text { Groundwater Use } \\
\text { MGD' } 1969 \\
\end{array}$ & $\begin{array}{c}\text { Projected } \\
\text { Average Demand } \\
\text { MGD* } 2020 \\
\end{array}$ & $\begin{array}{c}\text { Projected } \\
\text { Peak Demand } \\
\text { MGD } 2020^{2}\end{array}$ \\
\hline \multicolumn{5}{|l|}{ Within 5 miles of site } \\
\hline Miamisburg & $\mathrm{U}$ & 1.570 & 11.761 & 17.642 \\
\hline Germantown & $\mathrm{U}$ & 0.444 & 2.157 & 3.775 \\
\hline Franklin & D & 2.013 & 21.120 & 31.680 \\
\hline West Carrollton & $\mathrm{U}$ & 0.928 & 5.634 & 9.860 \\
\hline Springboro & $\mathrm{D}$ & 0.211 & 4.852 & 8.492 \\
\hline \multicolumn{5}{|c|}{ Within 10 miles of site } \\
\hline Farmersville & $\mathrm{U}$ & 0.069 & 0.663 & 1.160 \\
\hline New Lebanon & $\mathrm{U}$ & 0.350 & 1.919 & 3.358 \\
\hline Oakwood & $U$ & 1.081 & 2.011 & 3.017 \\
\hline Middletown & $\mathrm{D}$ & 7.815 & 20.168 & 30.252 \\
\hline \multicolumn{5}{|l|}{ Greater Moraine } \\
\hline Sanitary District & U & 14.295 & 61.446 & 92.169 \\
\hline \multicolumn{5}{|c|}{ Within 15 miles of site } \\
\hline Dayton & $\mathrm{U}$ & 61.142 & 192.836 & 289.254 \\
\hline \multicolumn{5}{|l|}{ Dayton State } \\
\hline Hospital & $\mathrm{U}$ & 0.016 & 0.023 & 0.040 \\
\hline Monroe & $D$ & 0.254 & 1.840 & 3.220 \\
\hline Trenton & $\mathrm{D}$ & 0.363 & 2.404 & 4.207 \\
\hline Gratis & $\mathrm{U}$ & 0.017 & 0.131 & 0.229 \\
\hline West Alexandria & $\mathrm{U}$ & 0.124 & 0.280 & 0.490 \\
\hline
\end{tabular}

"Million gallons per day. 


\subsection{APPLICABLE STANDARDS -}

Analytical results of groundwater samples collected from Mound monitoring wells are compared with Federal primary drinking water standards (40 CFR 141-143) in this report. Although drinking water standards do not apply to monitoring wells, they are a convenient reference for comparison. Federal secondary drinking water standards are not addressed in this report because they are primarily aesthetic guidelines ( $40 \mathrm{CFR}$ 143.1).

\subsection{DESCRIPTION OF GROUNDWATER PROGRAM}

The Main Hill of the Mound site is underlain by shale and thinly bedded limestone bedrock. Water within the shale is thought to be transmitted along fractures until deflected laterally at the intersections of competent shale beds unaffected by fracturing. This water then emerges at the surface as seeps (Figure 6-3). Groundwater from wells and seeps on the Main Hill has a history of tritium and VOC contamination and may serve as a source of contamination into the onsite valley to the south and into the BVA to the west. The groundwater monitoring program uses a network of sampling sites on and off the Mound site, consisting of the seeps (Figure 6-3) and onsite and offsite wells (Figure 6-4).

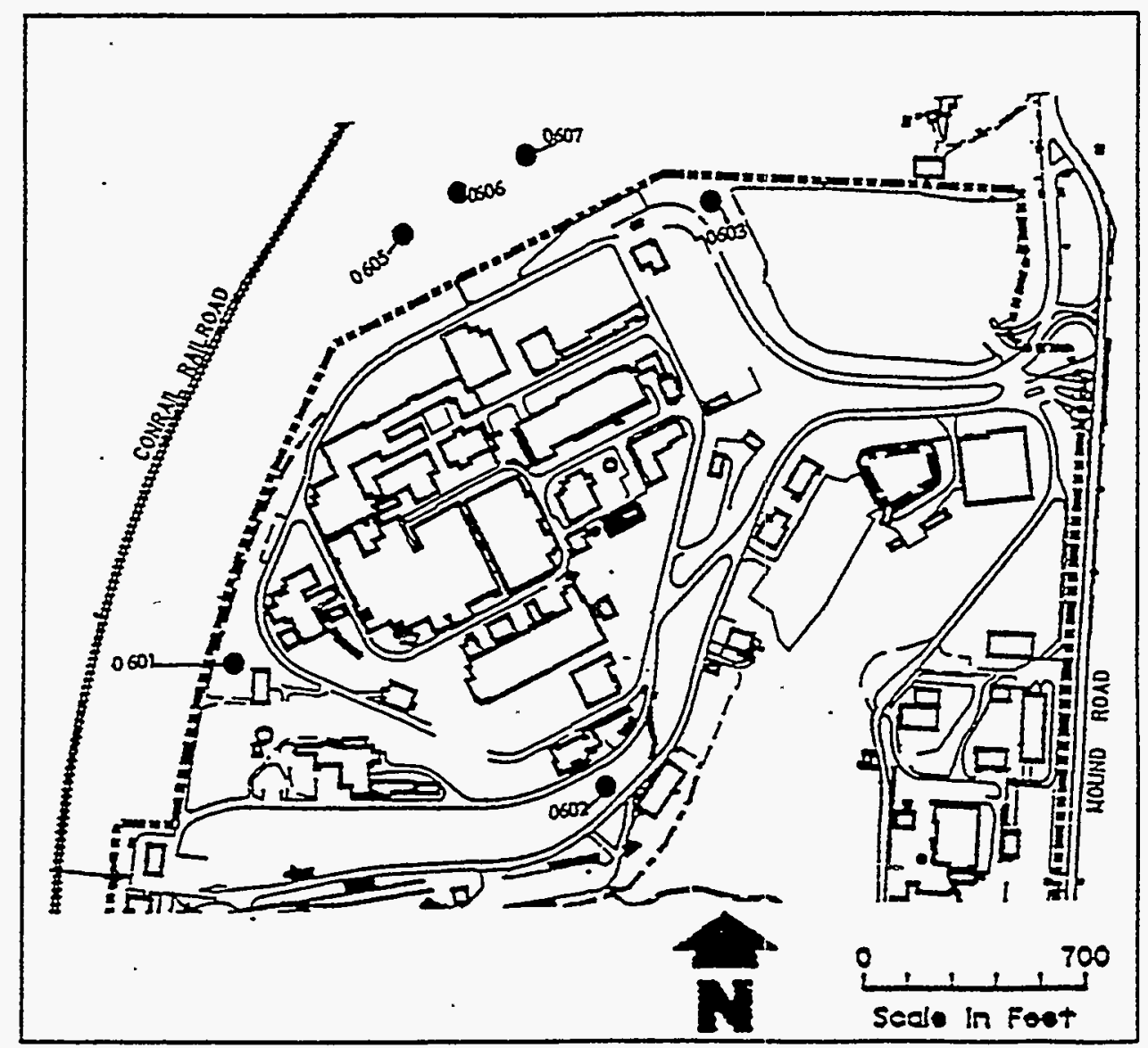

Figure 6-3. Groundwater seep sampling locations on the Main Hill 


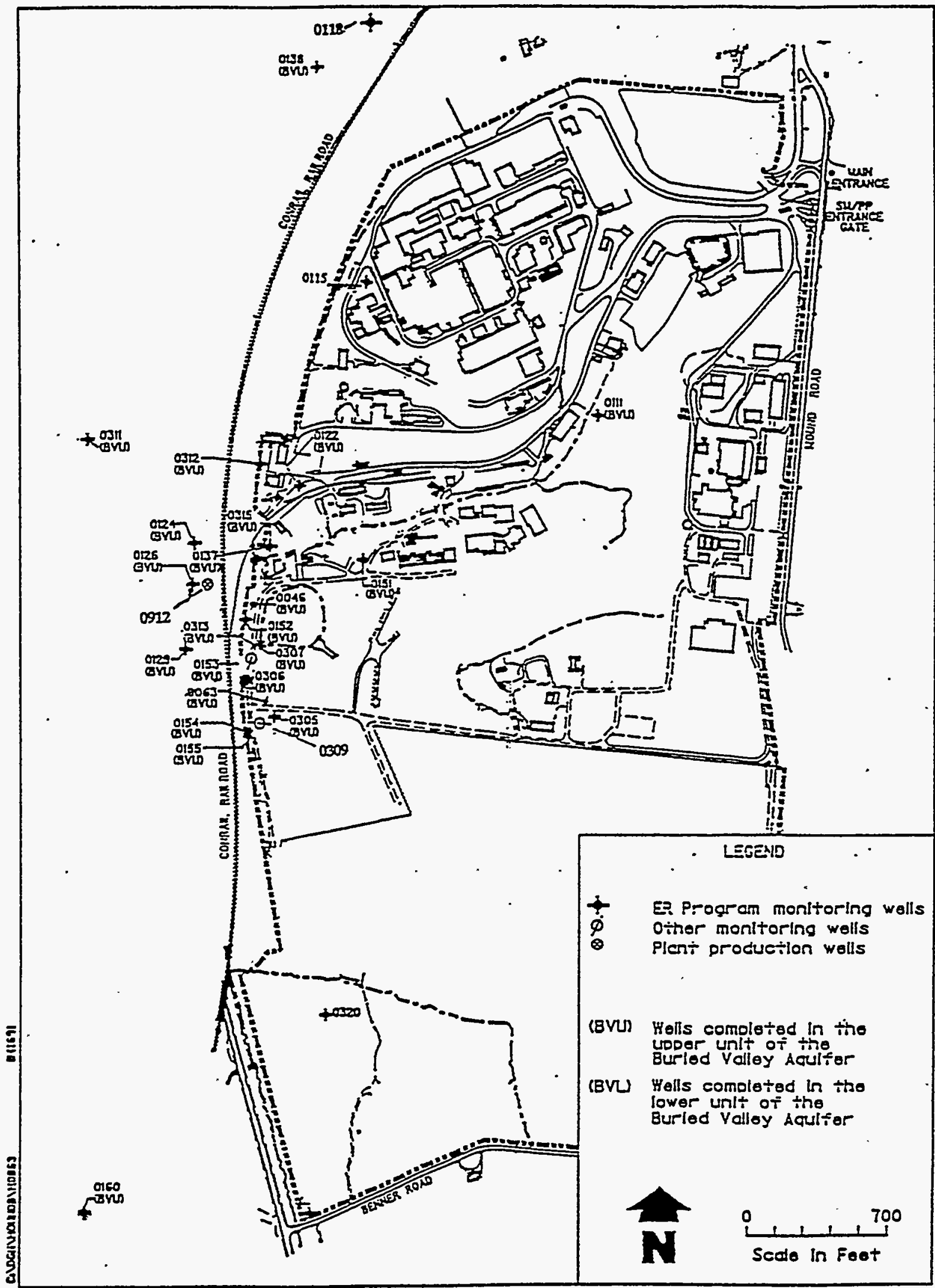

- Figure 6-4. Water quality monitoring network for wells in the upper and lower units of the Buried Valley Aquifer 
Observations of contaminant concentrations in the groundwater on the Main Hill have determined that the following contaminants exceed primary drinking water standards:

- radioactive contaminants - tritium

- VOCcontaminants - trichloroethene and tetrachloroethane

\subsubsection{Tritium Contamination}

\subsubsection{Tritium Contamination in Seeps}

Tritium, recognized as a persistent contaminantin the seeps since 1986(DOE 1987), has been the focus of various extensive investigations. Table 6-2 presents tritium concentrations measured in the Main Hill seeps. The highest concentration was measured in seep 601. Tritium concentrations at all sampled seeps, except 603 , exceeded the drinking water standard of $20 \mathrm{nCi} / \mathrm{L}$ for some sampling events in 1991. However, tritium concentrations have decreased significantly since discovery of the contamination in 1986.

\subsubsection{Tritium Contamination in the BVA}

Through the Potable Water Standards Project (Dames and Moore August 1976) and the Buried Valley Aquifer Evaluation Project (Dames and Moore December 1976), tritium levels in the BVA have been maintained in compliance with regulatory standards. The sediment in the MiamiErieCanal has been identified as a probable source of contamination to the BVA. As a follow-up to these projects, Mound monitors tritium levels in the groundwaterin the vicinity of the Plant weekly. Abandoned Miamisburg production well (shown on Figure 6-4 as No. 0912) is sampled at least monthly. When the concentration of tritium exceeds $20 \mathrm{nCi} / \mathrm{L}$, the well is pumped until concentrations are below $10 \mathrm{nCi} / \mathrm{L}$. Discharge is routed through a closed pipe to the Great Miami River. In the last five years, it was necessary to pump the Miamisburg well No. 2 five times: May 1 to May 27, 1986; November 3 to November 5, 1987; July 25 to August 2, 1989; July 20 to July 24, 1990; and May 23 to May 28, 1991. The influence the 1991 pumping activity had on tritium concentrations in the well is shown on Figure 6-5.

\section{Table 6-2. Tritium Concentrations in Mound Seep Sites in 1991}

\begin{tabular}{lrrrr}
\hline \multirow{2}{*}{ Site* } & No. & \multicolumn{3}{c}{ Tritium (nCi/L) } \\
\cline { 3 - 5 } & Samples & Minimum & Maximum & Average \\
\hline 0601 & 344 & 45.4 & 154.6 & 100.8 \\
0602 & 18 & 4.2 & 57.2 & 20.6 \\
0603 & 1 & 1.1 & 1.1 & 1.1 \\
0605 & 38 & 5.1 & 58.7 & 39.4 \\
0606 & 10 & 3.6 & 34.4 & 22.7 \\
0607 & 304 & 6.0 & 32.2 & 18.2 \\
& & & & \\
\hline
\end{tabular}

*Sites shown on Figure 6-3, p. 6-6. 


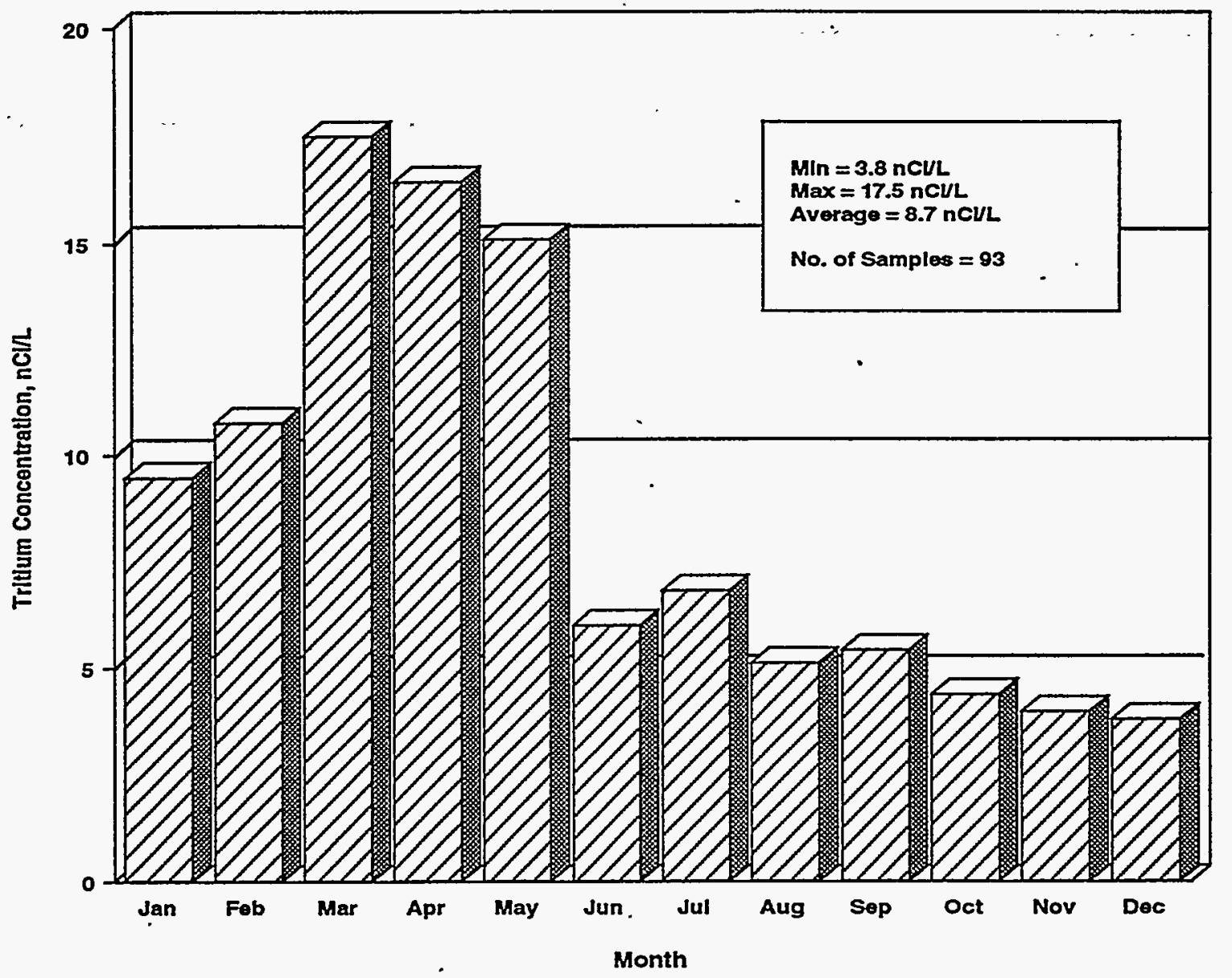

Figure 6-5. Monthly average tritium concentrations in abandoned Miamisburg Well No. 2

Table 6-3 presents tritium concentrations in groundwater samples collected from monitoring wells in the BVA during 1991. All concentrations were less than the EPA drinking water standard of $20 \mathrm{nCi} / \mathrm{L}$ with the exception of one sample from Well 305 , which appears to be an anomaly.
Geologic records and well concentration information for the wells are presented in the Site Scoping Report: Volume 2 - Geologic Log and Well Information (DOE 1990). Tritium concentrations measured in the monitoring wells during 1991 ranged from $0.7 \mathrm{nCi} / \mathrm{L}$ to $24.0 \mathrm{nCi} / \mathrm{L}$. The highest concentrations were measured at monitoring wells located along the western Mound Plant boundary. 
Table 6-3. Tritium Concentrations in BVA Monitoring Wells in 1991

\begin{tabular}{lcc}
\hline & \multicolumn{2}{c}{ Tritium (nCi/L) } \\
\cline { 2 - 3 } Well* & 1 st Quarter & \\
0063 & 7.0 & 6.4 \\
0118 & - & 0.7 \\
0122 & 4.9 & 4.7 \\
0126 & 1.9 & 7.4 \\
0129 & 2.3 & 2.1 \\
0138 & - & 4.8 \\
0152 & 9.0 & 8.5 \\
0154 & 4.6 & 3.9 \\
0155 & 2.2 & 2.5 \\
0305 & 24.0 & 7.1 \\
0306 & 6.6 & 9.3 \\
0307 & 8.4 & 9.2 \\
0312 & 9.9 & 9.6 \\
0313 & 6.5 & 6.9 \\
0315 & 6.7 & 4.8 \\
\hline
\end{tabular}

*Well locations shown on Figure 6-4, p. 6-2.

\subsubsection{VOC Contamination}

\subsubsection{VOC Contamination in Seeps}

Groundwater samples collected in 1988 from seeps on the Main Hill first established the presence of VOCs in seeps 0601, 0602, 0605, and 0607 (DOE April 1991). Table 6-4 represents concentrations of VOCs detected at seeps for 1991 sampling events. Trichloroethene exceeded the $5-\mu \mathrm{g} / \mathrm{L}$ drinking water standard at seeps 0602 and 0605 with concentrations of 45 and $5.9 \mu \mathrm{g} / \mathrm{L}$, respectively. Additionally, trichlorothene was detected at seeps 0601 and 0607 at concentrations of 4.7 and $3.0 \mu \mathrm{g} / \mathrm{L}$, respectively.

Other contaminants include tetrachloroethene at seep 0601 , which was measured at $9.4 \mu \mathrm{g} / \mathrm{L}$. Groundwater samples collected from seeps 0602 and 0607 contained 1,1,1,-trichloroethane. However, measured concentrations were below the drinking water standard of $200 \mu \mathrm{g} / \mathrm{L}$. 
Table 6-4. Volatile Organic Concentrations

in Groundwater Samples Collected from Seeps in 1991.

\begin{tabular}{|c|c|c|c|}
\hline \multirow[b]{2}{*}{ Seep* } & \multirow[b]{2}{*}{ Organic Compound } & \multicolumn{2}{|c|}{$\mu \mathrm{g} / \mathrm{L}$} \\
\hline & & Sample Result & $\overline{\mathrm{MCL}^{2}}$ \\
\hline \multirow[t]{4}{*}{0601} & Dichloromethane & $\mathrm{ND}^{\mathrm{b}}$ & $5^{c}$ \\
\hline & 1,1,1-Trichloroethane & ND & 200 \\
\hline & Trichloroethene & 4.7 & 5 \\
\hline & Tetrachlorethene & 9.4 & 5 \\
\hline \multirow[t]{5}{*}{0602} & Trichloromethane & 0.5 & $100^{d}$ \\
\hline & 1,2-Dichloroethene (total) & 14 & $70^{\circ}$ \\
\hline & 1,1-Dichloroethene & 1.5 & $\mathrm{NA}^{\mathrm{f}}$ \\
\hline & Trichloroethene & 45 & 5 \\
\hline & 1,1,1-Trichloroethane & 2.5 & 200 \\
\hline \multirow[t]{4}{*}{0605} & 1,1,1-Trichloroethane & ND & 200 \\
\hline & 1,2-Dichloroethylene.(total) & 3 & $70^{\circ}$ \\
\hline & Trichloromethane & ND & $100^{\mathrm{d}}$ \\
\hline & Trichloroethene & 5.9 & 5 \\
\hline \multirow{8}{*}{0607} & 1,1,1-Trichloroethane & 1.2 & 200 \\
\hline & Dichloromethane & ND & $5^{\mathrm{c}}$ \\
\hline & Acetone & ND & NA \\
\hline & 1,2-Dichloroethene & 1.8 & $70^{\circ}$ \\
\hline & Trichloromethane & ND & $100^{\mathrm{d}}$ \\
\hline & Toluene & ND & $2000^{c}$ \\
\hline & Tetrachlorethene & ND & 5 \\
\hline & Trichloroethene & 3.0 & 5 \\
\hline
\end{tabular}

a MCL - Maximum Contaminant Level, based on Primary Drinking Water Standards

b ND indicates that a contaminant was not detected

c Proposed limit

d $100 \mu \mathrm{g} / \mathrm{L}$ for total of trihalomethanes

- $\mathrm{MCL}$ for cis $70 \mu \mathrm{g} / \mathrm{L}$, trans $100 \mu \mathrm{g} / \mathrm{L}$

f NA - no current MCL exists

* Locations shown on Figure 6-3, p. 6-6. 


\subsubsection{VOC Contamination in the BVA}

Within the Mound Plant boundary, there are 18 monitoring wells in the upper unit of the BVA that have been sampled quarterly since 1988 . Results indicate the presence of VOC contamination. Based on sampling of the present monitoring well network, concentrations appear to be greatest along the western Plant boundary, immediately southwest of the Main Hill and plant drainage ditch, and to generally decrease southward.

From north to south, 10 monitoring wells [0312, 0152, 0307, 0313, 0153, 0306, 0063, 0305, 0154, and 0155 (Figure 6-4)] exhibit concentrations of VOCs that exceed the EPA drinking water standards (Table 6-5). Trichloroethene and tetrachloroethene are the principal compounds, but tetrachloromethane and 1,2-dichloroethene have also been detected intermittently. Continuing southward, the plant production wells Nos. 1, 2, and 3 (Figure 4-5) exhibit VOC contamination, principally trichloroethene, along with other trace compounds (Table 6-6). These wells supply water for entire Plant use. However, Well No. 1 has been used sparingly for the past several years because it is located closest to the suspected source of VOC contamination.

Along the plant drainage ditch, within the plant boundary, VOC contamination appears to be limited. Only one monitoring well, 0111 (Figure 6-4), exhibits traces of trichloromethane. VOC contamination has not been detected or only sporadic detections have been seen in the past in the remaining wells including $0111,0119,0125,0314$, and $0 i 51$.

West of Mound Plant, 18 monitoring wells are sampled for VOCs quarterly for the ER Program. Fourteen of these are in the upper unit of the BVA and four in the lower unit (Figure 6-4). Only limited VOC contamination has been detected to date, and only monitoring well 0126 has consistently shown traces of tetrachloroethene (Table 6-7). The 1991 sampling showed traces of 1,1,1-trichloroethane in six wells (Table 6-7).

Table 6-5. Volatile Organic Concentrations

in Groundwater Samples Collected from Onsite

Wells in 1991

\begin{tabular}{|c|c|c|c|c|}
\hline \multirow[b]{2}{*}{ Welli } & \multirow[b]{2}{*}{ Parameter } & \multicolumn{3}{|c|}{$\mu g / L$} \\
\hline & & 1st quarter & 2nd quarter & $\overline{\mathrm{MCL}}^{\text {\& }}$ \\
\hline \multirow[t]{4}{*}{0046} & Trichloroethene & 3.3 & 1.6 & 5 \\
\hline & 1,1,1-Trichloroethane & 0.7 & $\mathrm{ND}^{\mathrm{c}}$ & 200 \\
\hline & Tetrachlorethene & 4.7 & 1.9 & 5 \\
\hline & 1,2-Dichloroethene (total) & 1.4 & 2.0 & $70^{d}$ \\
\hline \multirow[t]{6}{*}{0063} & Trichloromethane & 10 & 7.2 & $100^{e}$ \\
\hline & 1,2-Dichloroethene (total) & 21 & 13 & $70^{\mathrm{f}}$ \\
\hline & $1,1,1$-Trichloroethane & 0.7 & ND & 200 \\
\hline & Tetrachloromethane & 2.4 & 2.0 & 5 \\
\hline & Trichloroethene & 49 & 43 & 5 \\
\hline & Tetrachlorethene & 24 & 20 & $5^{-}$ \\
\hline
\end{tabular}


Table 6-5. Volatile Organic Concentrations

in Groundwater Samples Collected from Onsite

Wells in 1991 (continued) .

\begin{tabular}{|c|c|c|c|c|}
\hline \multirow[b]{2}{*}{ Well $\uparrow$} & \multirow[b]{2}{*}{ Parameter } & \multicolumn{3}{|c|}{$\mu \mathrm{g} / \mathrm{L}$} \\
\hline & & $\overline{\text { 1st quarter }}$ & 2nd quarter & $\overline{\mathrm{MCL}}$ \\
\hline 0111 & Trichloromethane & $\mathrm{NS}^{\mathrm{b}}$ & 1.7 & $100^{\circ}$ \\
\hline \multirow[t]{2}{*}{0115} & Tetrachlorethene & 0.7 & 0.3 & 5 \\
\hline & Trichloroethene & 1.8 & 1.4 & 5 \\
\hline \multirow[t]{2}{*}{0137} & Trichloroethene & NS & $4^{*}$ & 5 \\
\hline & Tetrachloromethane & NS & $2^{*}$ & 5 \\
\hline \multirow{3}{*}{0152} & Trichloromethane & 1.3 & $\therefore 1.1$ & $100^{\circ}$ \\
\hline & Trichloroethene & 9.2 & 8.9 & 5 \\
\hline & Tetrachlorethene & 5.5 & 4.0 & 5 \\
\hline \multirow[t]{4}{*}{0153} & 1,1,1-Trichloroethane & NS & 0.3 & 200 \\
\hline & Trichloromethane & NS & 1.1 & $100^{\circ}$ \\
\hline & Trichloroethene & NS & 17 & 5 \\
\hline & Tetrachlorethene & NS & 7.6 & 5 \\
\hline \multirow[t]{5}{*}{0154} & 1,1,1-Trichloroethane & 0.3 & 0.3 & 200 \\
\hline & Trichlormethane & 0.6 & 0.7 & $100^{\circ}$ \\
\hline & 1,2-Dichloroethene (total) & 15 & 38 & $70^{\mathrm{f}}$ \\
\hline & Trichloroethene & 5.4 & 10 & 5 \\
\hline & Tetrachlorethene & 1.1 & 1.3 & 5 \\
\hline \multirow[t]{5}{*}{0155} & Trịchloroethene & 3.5 & 7.2 & 5 \\
\hline & Trichloromethane & 0.9 & ND & $100^{\circ}$ \\
\hline & 1,2-Dichloroethene (total) & 8.2 & 24 & $70^{f}$ \\
\hline & 1,1,1-Trichloroethane & ND & 1.0 & 200 \\
\hline & Tetrachlorethene & 0.4 & 0.7 & 5 \\
\hline \multirow[t]{7}{*}{0305} & trans-1,2-Dichloroethene & 1.6 & ND & $100^{\mathrm{d}}$ \\
\hline & Trichloromethane & 6.1 & 7.7 & $100^{\circ}$ \\
\hline & 1,1,1-Trichloroethane & 0.6 & 0.9 & 200 \\
\hline & Tetrachloromethane & 1.8 & 3.0 & 5 \\
\hline & 1,2-Dichloroethene (total) & 58 & 22 & $70^{\circ}$ \\
\hline & Trichloroethene & 29 & 50 & 5 \\
\hline & Tetrachlorethene & 23 & 23 & 5 \\
\hline \multirow[t]{3}{*}{0306} & 1,1,1-Trichloroethane & 0.5 & 0.8 & 200 \\
\hline & Trichloroethene & 16 & 17 & 5 \\
\hline & Tetrachlorethene & 6.7 & 7.5 & 5 \\
\hline
\end{tabular}


Table 6-5. Volatile Organic Concentrations in Groundwater Samples Collected from Onsite

Wells in 1991 (continued)

\begin{tabular}{|c|c|c|c|c|}
\hline \multirow[b]{2}{*}{ Well $\dagger$} & \multirow[b]{2}{*}{ Parameter } & \multicolumn{3}{|c|}{$\mu \mathrm{g} / \mathrm{L}$} \\
\hline & & 1st quarter & 2nd quarter & $\overline{\mathrm{MCL}^{\mathrm{a}}}$ \\
\hline \multirow[t]{4}{*}{0307} & Trichloromethane & 1.7 & 1.0 & $100^{\circ}$ \\
\hline & Tetrachloromethane & 1.8 & 1.8 & 5 \\
\hline & Trichloroethene & 9.6 & 9.6 & 5 \\
\hline & Tetrachlorethene & 13 & 11 & 5 \\
\hline \multirow{6}{*}{0312} & 1,2-Dichloroethene (total) & 23 & 12 & $70^{\mathrm{f}}$ \\
\hline & Trichloroethene & 28 & 15 & 5 \\
\hline & 1,1,1-Trichloroethane & 0.4 & ND & 200 \\
\hline & Tetrachloromethene & 1.5 & ND & 5 \\
\hline & Trichloromethane & 0.5 & ND & $100^{\circ}$ \\
\hline & trans-1,2-Dichloroethene & 1.1 & $\mathrm{ND}$ & $100^{d}$ \\
\hline \multirow{4}{*}{0313} & Trichloromethane & 1.8 & 1.3 & $100^{e}$ \\
\hline & Tetrachloromethane & 2.7 & 2.5 & 5 \\
\hline & Trichloroethene & 8.4 & 7.7 & 5 \\
\hline & Tetrachlorethene & 15 & 11 & 5 \\
\hline \multirow{5}{*}{0315} & Trichloromethane & 0.9 & ND & $100^{e}$ \\
\hline & 1,2-Dichloroethene (total) & 1.5 & 1.2 & $70^{\mathrm{f}}$ \\
\hline & Tetrachloromethane & 2.7 & 3.6 & 5 \\
\hline & Trichloroethene & 3.6 & 5.0 & 5 \\
\hline & Tetrachlorethene & 0.4 & ND & 5 \\
\hline 0320 & 1,2-Dichloroethene (total) & NS & 0.7 & $70^{f}$ \\
\hline
\end{tabular}

"MCL - Maximum Contaminant Level, based on Primary Drinking Water Standards

${ }^{\mathrm{b} N S}$ - Well was not sampled

${ }^{\mathrm{C} N D}$ - Contaminant was not detected

dProposed limit

${ }^{\circ} 100 \mu \mathrm{g} / \mathrm{L}$ for total of trihalomethanes

${ }^{\mathrm{f}} \mathrm{MCL}$ for cis $70 \mu \mathrm{g} / \mathrm{L}$, trans $100 \mu \mathrm{g} / \mathrm{L}$

*Estimated value less than the detection limit

$\doteqdot$ Well locations shown on Figure 6-4, p. 6-7. 
Table 6-6. Volatile Organic Concentrations in Onsite Production Wells in 1991

\begin{tabular}{lccccc}
\hline & No. & \multicolumn{3}{c}{$\mu \mathrm{g} / \mathrm{L}$} \\
\cline { 4 - 5 } Location* & Samples & Minimum & Maximum & Average & MCL $^{2}$ \\
\hline & & & & & \\
Well No.1 & & & & & \\
1,2-dichloroethene (total) & 67 & 1.50 & 18.80 & 5.66 & $70^{\circ}$ \\
trichloroethene & 67 & 1.75 & 6.50 & 3.39 & 5 \\
chloroform & 67 & 0.00 & 1.00 & 0.01 & 100 \\
tetrachloroethene & 67 & 0.00 & 0.90 & 0.36 & 5 \\
& & & & & \\
Well No. 2 & & & & & \\
1,2-dichloroethene (total) & 63 & 1.20 & 6.50 & 2.75 & $70^{\circ}$ \\
trichloroethene & 63 & 1.90 & 5.90 & 4.02 & 5 \\
chloroform & 63 & 0.00 & 0.50 & 0.02 & 100 \\
tetrachloroethene & 63 & 0.00 & 1.90 & 0.93 & 5 \\
& & & & & \\
Well No. 3 & & & & & \\
1,2-dichloroethene (total) & 22 & 0.00 & 5.00 & 1.17 & $70^{\mathrm{b}}$ \\
trichloroethene & 22 & 0.00 & 4.60 & 1.37 & 5 \\
chloroform & 22 & 0.00 & 0.00 & 0.00 & 100 \\
tetrachloroethene & 22 & 0.00 & 0.80 & 0.06 & 5 \\
& & & & & \\
& & & & & \\
\hline
\end{tabular}

a MCL - Maximum Contaminant Level, based on Primary Drinking Water Standards

${ }^{b} \mathrm{MCL}$ for cis $70 \mu \mathrm{g} / \mathrm{L}$, trans $100 \mu \mathrm{g} / \mathrm{L}$

*Well locations shown on Figure 4-5, p. 4-17. 
Table 6-7. Volatile Organic Concentrations

in Groundwater Samples Collected from Offsite

Wells in 1991

\begin{tabular}{|c|c|c|c|c|}
\hline \multirow[b]{2}{*}{ Well* } & \multirow[b]{2}{*}{ Parameter } & \multicolumn{3}{|c|}{$\mu \mathrm{g} / \mathrm{L}$} \\
\hline & & 1st quarter & 2nd quarter & $\overline{\mathrm{MCL}^{\mathrm{g}}}$ \\
\hline 0118 & 1,1,1-Trichloroethane & 0.5 & $N^{b}$ & 200 \\
\hline \multirow{3}{*}{0126} & 1,1,1-Trichloroethane & 0.4 & $\mathrm{ND}^{\mathrm{c}}$ & 200 \\
\hline & Tetrachloroethene & 0.4 & 0.5 & 5 \\
\hline & 1,1,2,2-Tetrachloroethane & 0.6 & ND & d \\
\hline 0129 & 1,1,1-Trichloroethane & 0.5 & 0.7 & 200 \\
\hline 0138 & 1,1,1-Trichloroethane & NS & 0.6 & 200 \\
\hline 0160 & 1,1,1-Trichloroethane & 0.4 & ND & 200 \\
\hline 0311 & 1,1,1-Trichloroethane & NS & 0.6 & 200 \\
\hline
\end{tabular}

'MCL - Maximum Contaminant Level

b NS - Well was not sampled

c ND - Contaminant was not detected

d No MCL established.

* Well locations shown on Figure 6-4, p. 6-7.

\subsubsection{Plutonium Analyses for Groundwater}

Samples from monitoring wells have been analyzed for plutonium-238 at least once since 1987. Recent (i.e., 1991 quarterly sampling rounds) plutonium-238 analyses indicate concentrations are less than the detection limit of the analytical method $(1.0 \mathrm{pCi} / \mathrm{L})$. The DOEDCG for plutonium-238 in water is $40 \mathrm{pCi} / \mathrm{L}$ (DOE Order 5400.5). Monitoring wells 0124, 0126, and 0129 (Figure 6-4) are located in the area where high plutonium concentrations were measured in canal sediments, but there is no current evidence that groundwater has been affected. 


\section{ENVIRONMENTAL SURVEILLANCE QUALITY ASSURANCE}

Summary: Mound participated in comparison exercises in which samples were analyzed from outside sources-DOE's Environmental Measurements Laboratory, the U.S. Environmental Protection Agency, and Analytical Products Group, Inc. Mound's analyses of a number of radiological and nonradiological substances agreed well with that of the external labs. Mound also has an internal Quality Assurance Program that includes the use of blank samples, internal standards, and duplicate samples. This Quality Assurance Program ensures the reliability of Mound data.

As an essential part of its Quality Assurance Program during 1991, Mound analyzed reference samples from outside sources: DOE's Environmental Measurements Laboratory (EML), EPA's NPDES Program, and a private laboratory, Analytical Products Group, Inc. (APG). The EML samples consisted of radionuclides in air filters, water, soil, and vegetation. The EPA and APG samples contained nonradioactive contaminants in water.
Table 7-1 contains Mound's March 1991 EML results. Eleven samples were within $20 \%$ and five were within $10 \%$. The vegetation sample at $33 \%$ is attributable to the fact that the concentration was near the detection limit, where a larger measurement error is expected.

The September 1991, comparison of Mound Quality Assurance Program results with EML results (Table 7-2) shows eight samples within $10 \%$, ten within $20 \%$, and one within $33 \%$.

Table 7-1. Mound DOE Quality Assessment Program Results for Radionuclides in Environmental Samples " (March 1991 Samples)

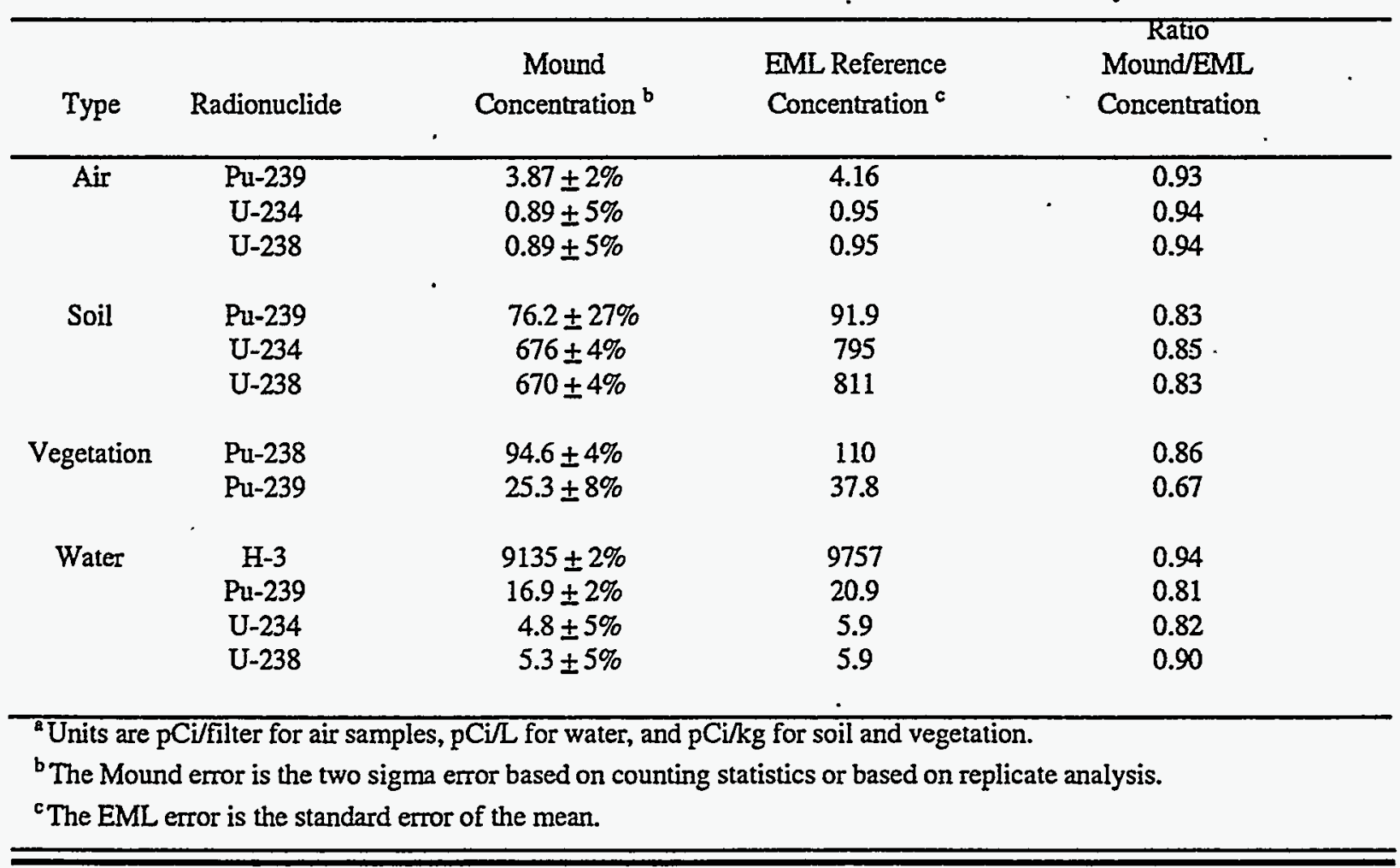


Table 7-2. Mound DOE Quality Assessment Program Results for Radionuclides in Environmental Samples ${ }^{2}$ (September 1991 Samples)

\begin{tabular}{ccccc}
\hline $\begin{array}{c}\text { Sample } \\
\text { Type }\end{array}$ & $\begin{array}{c}\ddots \\
\text { Radionuclide }\end{array}$ & $\begin{array}{c}\text { Mound } \\
\text { Concentration }^{\mathrm{b}}\end{array}$ & $\begin{array}{c}\text { EML Reference } \\
\text { Concentration }\end{array}$ & $\begin{array}{c}\text { Ratio } \\
\text { Mound/EML } \\
\text { Concentration }\end{array}$ \\
\hline Air & Pu-239 & $1.94 \pm 4 \%$ & 2.27 & 0.85 \\
& U-234 & $1.12 \pm 5 \%$ & 1.07 & 1.05 \\
& U-238 & $1.13 \pm 4 \%$ & 1.05 & 1.08 \\
Soil & Pu-239 & $219 \pm 8 \%$ & 198 & 1.11 \\
& U-234 & $736 \pm 5 \%$ & 780 & 0.94 \\
& U-238 & $716 \pm 5 \%$ & 780 & 0.92 \\
Vegetation & Pu-239 & $10.03 \pm 16 \%$ & & 1.02 \\
Water & H-3 & $2514 \pm 9 \%$ & 9.86 & 0.93 \\
& Pu-239 & $10.9 \pm 2 \%$ & 2700 & 0.79 \\
& U-234 & $13.5 \pm 2 \%$ & 13.8 & 1.08 \\
& U-238 & $13.5 \pm 2 \%$ & 12.5 & 1.05 \\
\hline
\end{tabular}

- Units are $\mathrm{pCi} /$ filter for air samples, $\mathrm{pCi} / \mathrm{L}$ for water, and $\mathrm{pCi} / \mathrm{kg}$ for soil.

b The Mound error is the two sigma error based on counting statistics or based on replicate analysis.

c The EML error is the standard error of the mean.

Mound's results for the 1991 EPA-NPDES Quality Assurance Program for the determination of nonradioactive parameters in water are shown in Table 7-3. All parameter values fell within the established warning and acceptance limits.

Also, as a parallel to the EPA-NPDES Program, in January and July of each year, Mound measures nonradioactive parameters in water in reference samples prepared by APG (Table 7-4). Two samples of different concentrations are analyzed for each parameter. The results are reported in the number of standard deviations from the average of all participating laboratories. EPA's acceptance and warning limits are 2.58 and 1.96 standard deviations from the average, respectively. Mound's highest standard deviation was 2.206; all others were below 0.88 . Mound's close agreement with EPA and APG results demonstrates its ability to accurately measure these nonradioactive parameters in water.
In addition to its external Quality Assurance Program, Mound has an internal Quality Assurance Program that consists of running blanks, internal standards, and duplicate samples. Analyzing blanks verifies the absence of excessive laboratory contamination ordetector background. The standard deviation of the blank values is used to calculate the lower detection limits. This step is important because many of the samples show contaminant concentrations at or below the lower detection limit. Analysis of duplicate samples and internal standards are performed to evaluate the precision of the analytical methods. Deviation from an expected value results in the review of the analytical process.

Mound's internal Quality Assurance Program and the close agreement between Mound and external labs in the EML, EPA, and APG comparison exercises demonstrate that Mound generates reliable data during its routine monitoring programs. 
Table 7-3. 1991 Mound EPA-NPDES Quality Assurance Program Results for the Determination of Nonradioactive Parameters in Water

\begin{tabular}{|c|c|c|c|c|c|}
\hline Parameters & $\begin{array}{l}\text { Mound } \\
\text { Value }\end{array}$ & $\begin{array}{l}\text { EPA } \\
\text { Value }\end{array}$ & $\begin{array}{l}\text { Acceptance } \\
\text { Limits }\end{array}$ & $\begin{array}{l}\text { Warning } \\
\text { Limits }\end{array}$ & $\begin{array}{l}\text { Performance } \\
\text { Evaluation }\end{array}$ \\
\hline \multicolumn{6}{|l|}{ Trace Metals $(\mu \mathrm{g} / \mathrm{L})$} \\
\hline Cadmium & 196 & 190 & $161-218$ & $168-211$ & Acceptable \\
\hline Chromium & 388 & 410 & $334-477$ & $352-459$ & Acceptable \\
\hline Copper & 738 & 730 & $656-817$ & $676-797$ & Acceptable \\
\hline Nickel & 431 & 430 & $383-485$ & $396-472$ & Acceptable \\
\hline Lead & 53 & 47.9 & $38.3-58.3$ & $40.8-55.8$ & Acceptable \\
\hline Mercury & 3.29 & 3.40 & $2.54-4.41$ & $2.78-4.18$ & Acceptable \\
\hline Zinc & 114 & 110 & $88.5-133$ & $94.1-128$ & Acceptable \\
\hline $\mathrm{pH}$ & 5.56 & 5.52 & $5.42-5.66$ & $5.45-5.64$ & Acceptable \\
\hline \multicolumn{6}{|c|}{ Miscellaneous Parameters (mg/L) } \\
\hline Total Suspended & & & - & & - \\
\hline Solids & 21.3 & 23.9 & $14.8-26.5$ & $16.3-25$ & Acceptable \\
\hline Oil and Grease & 16.2 & 17 & $9.07-22.1$ & $10.7-20.5$ & Acceptable \\
\hline Total Cyanide & 0.492 & 0.530 & $0.365-0.676$ & $0.404-0.637$ & Acceptable \\
\hline Total Residual & & & & & \\
\hline Chlorine & 0.092 & 0.110 & $0-0.246$ & $0.0099-0.210$ & Acceptable \\
\hline $\mathrm{NH}_{3}-\mathrm{N}$ & 4.27 & 4.20 & $3.30-5.09$ & $3.51-4.88$ & Acceptable \\
\hline \multicolumn{6}{|l|}{ Demands (mg/L) } \\
\hline COD & 63.8 & 65.4 & $49.3-75.8$ & $52.7-72.5^{\circ}$ & Acceptable \\
\hline 5-day BOD & 38.1 & 35.8 & $7.12-64.4$ & $16.4-55.1$ & Acceptable \\
\hline
\end{tabular}


Table 7-4. Summary of Mound's Performance in the Analytical Products Group Proficiency Environmental Testing Program for 1991

\begin{tabular}{|c|c|c|c|c|}
\hline \multirow{3}{*}{$\begin{array}{c}\text { Parameter Measured } \\
\text { in Water }\end{array}$} & \multicolumn{4}{|c|}{ 1st sample/2nd sample } \\
\hline & \multicolumn{2}{|c|}{$\begin{array}{c}\text { Average } \\
\text { Concentrations } \\
\text { Measured by Mound } \\
\end{array}$} & \multicolumn{2}{|c|}{$\begin{array}{c}\text { Standard Deviations } \\
\text { of Mound Results from } \\
\text { the Average of All Labs* }\end{array}$} \\
\hline & $\overline{J a n}$ & July & $\overline{\operatorname{Jan}}$ & July \\
\hline \multicolumn{5}{|l|}{ Trace Metals $(\mu \mathrm{g} / \mathrm{L})$} \\
\hline Cadmium & $93 / 141$ & $30 / 122$ & $0.08 / 0.48$ & $0.43 / 0.59$ \\
\hline Chromium & $51 / 180$ & $44 / 153$ & $0.27 / 0.08$ & $0.01 / 0.23$ \\
\hline Copper & $28 / 272$ & $50 / 128$ & $0.26 / 0.12$ & $0.16 / 0.86$ \\
\hline Nickel & $27 / 284$ & $32 / 259$ & $0.38 / 0.14$ & $0.18 / 0.34$ \\
\hline Lead & $50 / 260$ & $106 / 214$ & $0.31 / 0.54$ & $0.26 / 0.48$ \\
\hline Zinc & $70 / 120$ & $36 / 144$ & $0.27 / 0.42$ & $0.04 / 0.39$ \\
\hline $\mathrm{pH}$ & $5.77 / 7.85$ & $11.39 / 10.75$ & $0.32 / 0.11$ & $0.71 / 0.65$ \\
\hline \multicolumn{5}{|c|}{ Miscellaneous Parameters (mg/L) } \\
\hline Total Suspended Solids & $89.6 / 194.1$ & $72 / 339.7$ & $0.64 / 0.68$ & $0.81 / 0.76$ \\
\hline Oil and Grease & $4.7 / 28.5$ & $13.5 / 27.4$ & $0.29 / 0.16$ & $0.54 / 0.42$ \\
\hline Cyanide & $0.43 / 2.59$ & $0.05 / 2.73$ & $0.05 / 0.12$ & $0.27 / 0.07$ \\
\hline Residual Chloride & $0.83 / 2.02$ & $0.32 / 1.11$ & $0.45 / 0.88$ & $0.46 / 0.07$ \\
\hline $\mathrm{NH}_{3}-\mathrm{N}$ & $0.84 / 2.17$ & $0.20 / 2.53$ & $0.18 / 0.36$ & $0.13 / 0.30$ \\
\hline Demands (mg/L) & & & & \\
\hline BOD & $162 / 23.4$ & $107.2 / 19.67$ & $0.37 / 0.51$ & $0.11 / 0.16$ \\
\hline $\mathrm{COD}$ & $268 / 34$ & $173.8 / 31$ & $2.206 / 0.37$ & $0.23 / 0.13$ \\
\hline
\end{tabular}

* Warning limit 1.96

Acceptance limit 2.58 


\section{REFERENCES}

Bauer, L.R. May 1991. Monitoring the Fate of Radionuclides Released to the Environment, MLM-3756, EG\&G Mound Applied Technologies, Miamisburg, $\mathrm{OH}$.

Dames and Moore August 1976. Potable Water Standards Project Mound, Cincinnati, Ohio.

Dames and Moore December 1976. Evaluation of the Buried Valley Aquifer Adjacent to Mound, Cincinnati, Ohio.

EG\&G April 1991. Hydrogeology/Groundwater Contamination, Operable Unit 1, Area B, Technical Memo (3).

EG\&G March 1990. Groundwater Protection Management Program Plan - Mound Plant. Prepared by Roy F. Weston, Inc. for EG\&G Mound Applied Technologies.

Eimutis, E.C. and Mote, L.B. February 20, 1976. Development of an Atmospheric Diffusion Model for Optimum Location of Sampling Sites in the Mound Laboratory Environment, MRC-DA-520, Monsanto Research Corporation, Dayton, Ohio.

Sheehan, W.E., Curtis, M.L., and Carter, D.C. February 14, 1975. Development of a Low-Cost Versatile Method for Measurement of HTO and HT in Air, MLM-2205.

U.S. Department of Energy February 1992a. Remedial Investigation/Feasibility Study, Mound Plant, Miamisburg, Ohio.

U.S. Department of Energy February 1992b. Site Scoping Report, Volume 1 - Groundwater Data, February 1987 - July 1990 and Addendum, Environmental Restoration Program, U.S. Department of Energy, Albuquerque Operations Office, Albuquerque, New Mexico.
U.S. Department of Energy December 1990. Site Scoping Report: Volume 2 - Geologic Log and Well Information (Draft), Environmental Restoration Program, U.S. Department of Energy, Albuquerque Operations Office. Albuquerque, New Mexico.

U.S. Department of Energy January 1987. Mound Installation Generic Monitoring Plant/Site Specific Monitoring Plan (Draft), Albuquerque Operations Office, Albuquerque, New Mexico.

U.S. Department of Energy. DOE Order 5400.1. General Environmental Protection Program.

U.S. Department of Energy. DOE Order 5400.5. Radiation Protection of the Public and the Environment.

U.S. Environmental Protection Agency, Office of Radiation Programs June 1972. Environmental Radioactivity Surveillance Guide, ORP/SID, 722.

40 CFR 61, Subpart H. National Emission Standards for Emissions of Radionuclides Other than Radon from Department of Energy Facilities.

40 CFR 133. Environmental Protection Agency Regulations on Secondary Treatment Information.

40CFR 136. Guidelines Establishing Test Procedures for the Analysis of Pollutants.

40 CFR 141-143. National Primary Drinking Water Regulations Implementation, andNational Secondary Drinking Water Regulations.

40 CFR 265, 382. Interim Status Standards for Owners and Operators of Hazardous Waste Treatment, Storage, and Disposal Facilities-Open Burning, Waste Explosives. 
$\cdots \cdots \cdots \cdots \ldots$

$-1$

$=$

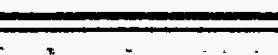




\section{DISTRIBUTION}

\section{EXTERNAL}

OSTI UC-702,707 (284)

\section{U.S. Department of Energy}

\section{DOE Headquarters}

Ralph A. Hagan, Site Action Team Leader, DP-642

Richard D. Hahn, Director, DP-64 (2)

Mary J. Jameson, Director, PA-1

Michael H. Kleinrock, Director, EM-22 (2)

Kathleen I. Taimi, Director, EH-22 (5)

John P. Sand, EM-453

Rear Admiral Winford G. Ellis, USN, Deputy Assistant Secretary for Military Applications, DP-20

Captain Jay McDonald, USN, Director, Office of Construction and Capital Projects, DP-20

DOE Albuquerque

Constance L. Soden, Director, EPD (3)

Charles P. Demos, Classification Officer, CIPS

David T. Flynn, Mound Installation Manager, ERPO

\section{DOE Dayton Area Office}

James A. Morley, Area Manager

George R. Gartrell, Deputy Area Manager

John A. Jones, Attomey

Michael A. Reker, ESH\&C Branch Chief
Dewain V. Eckman, P\&OS Branch Chief

Robert J. Grandfield, Administration Branch Chief

Irvin H. Schmidt, Q\&SA Branch Chief

Susan L. Smiley, Environmental Engineer

Arthur W. Kleinrath, Environmental Engineer

DOE Other

Rita D. Rosen, Technical Librarian, Environmental Measurements Laboratory

\section{DOE Contractors}

W.J. Bair, Manager

Life Sciences Center

Battelle Pacific Northwest Labs

R.E. Blake, Department Head

Environmental Control

Portsmouth Gaseous Diffusion Plant

Norbert Golchert, Head

Environmental Protection Section

ES\&H Department

Argonne National Laboratory

K.A. Hawley

Occupational and Environmental Safety

Battelle Pacific Northwest Labs

T.G. Hedahl, Manager

Environmental Programs

EG\&G Idaho

Hue-Su A. Hwang

Sandia National Labs

Craig Jensen, Radiation Safety Officer Battelle Columbus 
Richard Klein, Specialist

Environmental Protection

General Electric Company

Ken Margis, Group Leader

Environmental Surveillance

Los Alamos National Lab

J.R. Naidu, Section Head

Environmental Protection

Brookhaven National Lab

Keith R. Price

Geosciences Division

Battelle Pacific Northwest Labs

\section{J.S. Roberts, Manager}

Environmental Protection Division

Westinghouse Savannah River Company

James G. Rogers, Coordinator

Environmental Protection Activities

Martin Marietta Energy Systems

George:Setlock

Health, Safety and Environment

EG\&G Rocky Flats

John Sims

Lawrence Livermore National Lab

EG\&G, Inc.

W.H. Parker, III, Director

Environmental Programs

State and Federal Officials

The Honorable John Glenn

U.S. Senator

The Honorable Howard Metzenbaum

U.S. Senator

The Honorable Charles Horn

Ohio Senator
Office of the Honorable Russ Guerra, Jr.

Ohio Representative

The Honorable Rhine McLin

Ohio Representative

The Honorable Tom Roberts

Ohio Representative

The Honorable Tony Hall

U.S. Representative

The Honorable John Boehner

U.S. Representative

The Honorable Robert Corbin

Ohio Representative

The Honorable Robert Hickey

Ohio Representative

The Honorable Robert McEwen

U.S. Representative

The Honorable Robert Netzley

Ohio Representative

The Honorable Neal Zimmers, Jr.

Ohio Senator

\section{U.S. Environmental Protection Agency} (EPA)

EPA Headquarters

C.R. Cothern

Office of Drinking Water

J.W. Gunter

Office of Radiation Programs

EPA Eastern District Office

John Gierczak

EPA Region V, Chicago, IL

William Franz, Federal Facilities Coordinator

Steven Goranson, Chief

Environmental Monitoring Branch 
Gary Gulezian, Radiation Protection

Manager, Air and Radiation Division

Dianne Mally, Manager

Remedial Project

EPA. Cincinnati, $\mathrm{OH}$

Andrea I. Tanner

Office of Public Affairs

EPA, Montgomery, AL

Richàrd L. Blanchard

Eastern Environmental Radiation Facility

State of Ohio EPA (OEPA)

OEPA Columbus

Donald Schregardus, Director

Kenneth Applegate, Division of Public Water

Robert Berger

Public Interest Center

Tim Kruchbaum, Division of Solid and

Hazardous Waste Management

Patricia Walling, Chief

Office of Air Pollution Control

Robert E. Phelps, Manager

Industrial Wastewater Section

QEPA Southwest District Office

Thomas Winston, Chief

Martyn Burt, Unit Supervisor

Division of Water Pollution Control

Martha L. Hatcher, Site Coordinator

Division of Emergency and Remedial Response

Graham Mitchell, Chief

Wastewater Surveillance

\section{Other State of Ohio Agencies}

Kenneth B. Cole, Chief

Technology Branch

Emergency Management Agency

Robert Owen, Administrator

Radiological Health Unit

Ohio Department of Health

\section{County, Township, and City Offices}

Dick Church, Mayor

City of Miamisburg

- John Weithofer, City Manager

City of Miamisburg

Shirley Omietanski, President

Miami Township Trustees

Thomas Heine, President

Dayton Chamber of Commerce

Morton Nelson, Commissioner

Montgomery County Combined Health

District

Michaẹl Phillips, Director

Environmental Health

Montgomery County Combined Health

District

John A. Paul, Supervisor

Regional Air Pollution Control Agency

Paul Asmussen, Health Commissioner

City of Middletown

Nadine B. Grady

Environmental Radiation Program

Cincinnati Health Department

John J. Garner, Director

Sanitary Engineering

Montgomery County 
John R. Harvey, Health Commissioner

Butler County

Raj K. Sharma, City Engineer

City of Springboro

Larry Wiser, Director

Environmental Health

Warren County Health Department

James Rozelle, Chief Engineer

Water Resources

Miami Conservancy District

Media

Jim Barrett

WHIO-TV

John Brinckman

Dayton Daily News

Jim Carter

UPI Correspondent

Cheryl Craigie

WDTN-TV

Steve Diorio

WDTN-TV

Jim Hanna

AP Correspondent

Mike Hevel

WDTN-TV

Pamela Houston

WYMJ-FM

David Leonard

WING Radio

Kimm Mote

Miamisburg News
Bill Nance

WFCJ-FM

James Ripley

Dayton Daily News

Dick Roberts

WONE-AM/WTUE-FM

Charles VanSant

WVUD-FM

Lori Webster

WKEF-TV

\section{INTERNAL}

EG\&G Mound Applied Technologies

S.R. Adams

P.N. Ayers

L.R. Bauer (10)

C.T. Bishop

D.G. Carfagno

V.E. Castleberry

M.C. Becker

J.L. Clark

L.M. Coco

W.P. Davis

D.G. Draper

B.M. Farmer (50)

C.S. Friedman

W.D. Gloekler

R.R. Jaeger

C. Kinard

J.F. Lemming

D.E. Michel

D.A. Rakel

J.D. Ruffner

D.R. Rogers

W.H. Smith

M.S. Tullis

R.S. Tunning

R.E. Vallee

J.H. Walton

H.A. Woltermann

J.D. Yonko

Publications

Library (200) 